

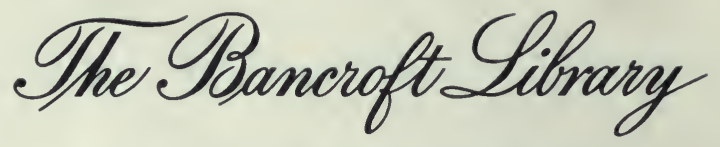

University of California - Berkeley

From the papers of

C. HART MERRIAM 


解ublications of the

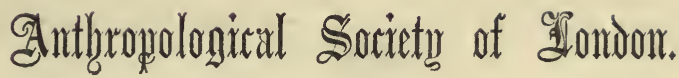

\section{THE PLURALITY OF THE HUMAN RACE.}

POUCHET. 



\title{
THE PLURALITY
}

OF

\section{THE HUMAN RACE:}

BY

\section{GEORGES POUCHET,}

DOCTOR OF MEDicine, LICENTIATE OF NATURA SCIENCE, AIDE-NATURALISTE IN THE MUSEUM OF ROUEN, MEMBER OF THE ANTIROPOLOGICAL SOCIETY OF PARIS, OORRESPONDING MEMBER OF THE ANTHROPOLOGICAL SOCIETY OF LONDON, ETO.

\author{
TRANSLATED AND EDITED,
}

(Jram the Sccond Evition),

BY

HUGH J. C. BEAVAN, F.R.G.S., F.A.S.L., OF THE MIDDLE TEMPLE, BARRISTER-AT-LAW.

\section{O N D O N :}

PUBLISHED FOR THE ANTHROPOLOGICAL SOCIETY, BY LONGMAN, GREEN, LONGMAN, AND ROBERTS, PATERNOSTER ROW. 
Digitized by the Internet Archive in 2007 with funding from Microsoft Corporation 


\section{DEDICATED}

To

THE RIGHT HONOURABLE

SIR EDWARD G. E. L. BULWER-LYTTON, BART., M.P., D.C.L., ETC.

rơitf all the respect

DUE TO A GREAT WRITER AND LEARNED MAN,

BY

HUGH J. C. BEAVAN. 



\section{EDITOR'S PREFACE.}

A FEW words by way of preface to a book on the Plurality of the Human Race are necessary as well as advisable. They are especially so when the Author and Editor differ considerably in their opinions, as in this case; and although it is by no means a sine quâ non that they should always agree, there are certain points on which a few lines may be required.

The Publishing Committee of the Anthropological Society of London honoured me by committing the translation and editing of this book to my care, and I set about the task with some diffidence, as this is probably the first work of the kind which has ever been given to the English literary world in a convenient and popular form. Such being the case, there will sometimes be found expressions which may be thought foreign; but I have preferred on these occasions giving the more literal translation, instead of one which possibly might fail to convey the Author's real meaning. In books containing such very peculiar ideas as those of M. Pouchet, it is requisite to be especially careful on this head.

Of the clever nature and terse expression of the work there can be little doubt, but I am sorry to find in it opinions with which I cannot at all agree, and in order to prove which, or rather endeavour to do so, science is strained in an unnatural manner. The theory of spontaneous generation is by no means a new one; but M. Pouchet can throw very little light on the subject, and leaves it as before-entirely unproved. The extreme sceptical nature of his views is much to be regretted, and in 
this especially the Author and Editor are in entire disagreement. The former is inclined to go out of his way to bring forward those views, when they were not required, and would have been better left unsaid.

We have, however, a new and extremely interesting field of investigation opened to us; but the more pains our author takes to explain and illustrate the wonders of our physical and psychological nature, the more he seems to disprove his own theory of spontaneous generation. Blackmore said-

\section{"Survey}

Nature's extended face, then, sceptics say, In this wide field of wonders can you find No art?"

But M. Pouchet does find art in nature; he tells us that its ways are intricate and manifold, but still that it all arises from some germ spontaneously generated, he cannot say how.

With this exception, which some may think no fault at all, I recommend this book heartily to the Fellows of the Society and the public generally. The clearness and even brilliancy of M. Pouchet's very peculiar style are soon discoverable, and it is not astonishing that his book has had a great success in France. That such will be the case in its English form is my sincere wish. I must thank my friend Mr. Carter Blake especially for many kind and valuable hints, and I need scarcely say, in conclusion, that as much care as possible has been taken with the translation and editing. I now commit this little work to the kind consideration of the Society and the world. It is for them to judge how my duties have been performed.

$$
\text { H. J. C. B. }
$$

London, August 30th, 1864. 


\section{PROFESSOR RICHARD OWEN.}

SIR,-I begged to be allowed to dedicate to you the first edition of this essay, in remembrance of the kind hospitality I formerly received from you in the cottage at Mortlake, and of our long conversations, in which you were so ready with good advice.

The debt of hospitality can never be repaid. I am happy to be able once more to express my gratitude to you, and my admiration of your great works.

\section{GEORGES POUCHET.}

Muséum de Rouen, July 1st, 1864. 



\section{AUTHOR'S PREFACE.}

I now offer to the public the second edition of a book whose success has far surpassed my expectations. Received with kindness by some, it has been violently attacked by others. It was denounced to the highest representatives of ,the university authority on which I depended, and I owed my escape from the trouble which might have been drawn on me,-because I brought forward a scientific opinion in disagreement with the books attributed to the prophet Moses,-to the justice of one of the most honoured members of the Institute. I owe a large debt of gratitude to my illustrious protector. The mind has advanced during six years, and the same troubles will not be met with again.

A good many alterations will be discovered in this Second Edition; this is always the case with science. In matters of imagination, when the artist has finished his work, he can cast it on the world and follow his fancy in some other way. If science were only composed of truths; its conditions would almost be the same for its disciples; but the seeker after truth is not a creator like an artist, he explains and reflects upon a world of facts, variable at every hour, according as hypotheses are changed into certainties, or certainties of yesterday into doubtful cases of to-day. It is, then, an incessant work of reparation and alteration, in order to maintain even the most modest work in harmony with the daily 
progress of science; I have made this work as perfect as was in my power. I have taken great care with the list of authorities. I have also indicated by their titles all the articles from periodicals, reviews, or academic collections, to which I refer the reader. I am sure that those who know what an ungrateful task it is to search such badly catalogued libraries as most of ours are, will give me credit for this part of my work. We can only see the expression of science at a given moment in Mémoires. Books are, after all, merely a summary : they are behind-hand even on the day they are published.

$$
\text { G. P. }
$$




\section{CONTENTS.}

Editor's Dedication Editor's Preface Áuthor's Dedication Author's Preface Contents INTRODUCTION

The Human Kingdom
CHAPTER I.

PAGE

vii

ix

xi

- $\quad$ xiii

- 1

Comparative Psychology

\section{CHAPTER III.}

The Order of Brmana

\section{CHA PTH III.}

38

CHAPTER IV.

Anatomical, Physiological, and Pathological Varieties

CHAPTER V.

Intellectual and Philological Varieties

CHAP'TER VI. 
CHAPTER VII.

The Influence of Hybridity

CHAPTER VIII.

Species

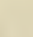

\section{CHAPTER IX.}

System

$\begin{array}{lllll}- & - & - & - & -134 \\ - & - & - & - & -153 \\ - & - & - & - & -156\end{array}$

INDEX OF SUBJECTS

156 


\section{TIIE PLURALITY OF THE IUMAN RACE.}

\section{INTRODUCTION.}

For a long period, in mediæval days, science was to most people what it was to Servetus, a simple paraphrase or glossary of a revealed text. In this was the truth, and if observation itself seemed sometimes contradictory, it was certain that there was some mistake; it was necessary to re-examine the contested question, and by dint of inquiring into the facts, they were altered so wisely, that in the end they always were found to agree.

All over the East, among the Semitic race,* that which above all other possesses respect for authority, science still lives. Without the law there is no science, and the Korán is what the books of the sons of Israel and the writings of the apostles were in the middle ages, the great, the only authority, to which everything was referred. $\dagger$

* We must here inform the reader, once for all, that we shall use, until we say anything to the contrary, the word "race," to designate the different natural groups of the human genus (genus Homo). We intend definitely to prove that these groups constitute veritable species. M. de Quatrefages has on this matter reproached us with a confusion, which is accounted for partly by the incorrectness of his quotation. He makes us say, "The plurality of original races, otherwise the plurality of the species, of the genus ' man'" (Unité de l'Espèce Humaine, 1861, p. 309). It stands as follows in our own text: "The original plurality of races, otherwise the plurality of the species composing the genus 'man,' " etc. It is evident that the confusion which is found in these words is entirely voluntary.

+ One day, I was talking with one of the principal officers of MehemetSaïd, at Korosko, in Nubia, about the earthquake which was felt in Lower Egypt on the 12th of October, 1856. He asked me the cause of this phenomenon. I attempted an explanation suited to the understanding of a man 
If science has shone with a bright light in the East, this was due solely to the introduction of a more human philosophy, born among another race, and conveyed there by the works of Aristotle and the neo-Platonists. The East was inspired for an instant with these foreign doctrines, which it would have been incapable of originating itself. It revived for a century or two under their influence, but soon everything reverted to a former state of order; having shone in the barbarism of a pure theism, whence it would never have come out without the contact of a world extrinsic and superior to certain considerations, without the momentary education which it had thus received from it.

All the sciences are not in the same intimate relation with the texts called revealed; the mathesiological order is that in which the sciences have had, and could have, the least to suffer from religious influence ; in the first place, mathematics, which, from their nature, would never have known how to yield; and, lastly, geology and anthropology, allied by intimate relations to the Divine tradition of the first chapter of Genesis. But see how geology, which we thought for so long a time was in agreement with it, grows more distant every day as new discoveries are multiplied. The pretended epochs see, day by day, that their artificial limits are disappearing, now that one finds reptiles in coal-fields and mammalia in Trias.

Anthropology in France seems, at last, to desire to free itself from the shameful yoke which has for so long paralysed its flight. In its turn it claims independence. But, we would declare this, that the principle of authority, defeated on so many points, has concentrated its highest efforts behind this last rampart, calling to its aid the pretence of morality and propriety. The question of the unity or the plurality of the human race, so far as relates to species, is only a scientific

who was without the slightest knowledge of this part of scientific information. He replied by telling me the history of the cow who throws the earth from one horn to the other, saying, that this was written, and therefore, such a belief ought to suffice him.

[With this opinion may be compared the doctrine of the Muyscas or Chibchas of New Granada, who consider that the earth is supported by Chibchacum, their deity, on pillars of guiacum-wood, and that earthquakes are produced by his shifting the burden from one shoulder to the other.-EDrTor.] 
one; but others make of it a question of principle, as in the time of Galileo, when it was a matter of overturning the ideas of the old world, supported by a testimony which was not allowed to be doubted. So the struggle is a sharp one;* it is felt that it refers almost to a dogma, and not merely to an accessory fact. Science clashes there with religion, as is the case with geology, and as formerly with astronomy; but in no way is the shock so violent, in no way can its consequences be as great. Anthropology, more than any other science, ought to produce immense results. $\dagger$ Who does not see that the abyss becomes every day deeper under the belief of the past, and that science, at a given moment, will become the foundation of more perfect morality?

This antagonism is the first difficulty which we find at the threshold of anthropology. We should have wished to have entered upon our subject without being obliged, not absolutely to discuss it, but merely to show the disputed point in the question. Unfortunately, the example has been given us; we must follow it. Two schools are to be found in anthropology; one called that of the Polygenists, the other that of the Monogenists, $\ddagger$ two words which came from America, and which we receive because they have the great advantage of being clear and precise, determining, by the opposing point of their doctrines, two distinct schools, the one recognising but one family in the human race, of which some members have alone preserved the primitive type-altered everywhere else; the other school recognising no direct relationship among the races of mankind. The Polygenistic school is comparatively modern; the founders of anthropology-the Blumenbachs and the Prichards-belonged to the other. Now, if they took their stand on an entirely philosophic or experimental point of view, we

* It is only necessary, in order to be sure of this fact, to glance over the Bulletins de la Société d'Anthropologie, the creation of which is due above all to the indefatigable zeal of a partisan of the doctrines which we defend-to M. P. Broca.

t Anthropology is not the only branch in modern science which opens new paths to the human mind: see Michelet, L'Insecte, p. 106; see also Bourdet, Traité d'éducation positive, 1863.

I This name has been definitely adopted in France in preference to that of "Unitarians" (Unitaires), used by M. de Gobineau. 
should be very badly received now-a-days if we were to reconsider the question upon a burning soil. It has not been so, however. Most Monogenists* have, up to the present time, done the universal wrong of invoking, in proof of their ideas, an authority which it is not allowable to discuss. Science is neither a special attribute of privileged castes, nor given to certain times in preference to others; it has never been obliged to wait for a revelation; it is universal, and all men, endowed with the same faculties, have always been able, in all countries and at all times, to carry it as far, when they have had the same means and the same occasions of observation; it is thus that psychology, based upon simple reflection, has not farther progressed in our days than at Athens or at Alexandria; from Plato to Descartes there is only the distance between one system and the other.

"Historians of that which is," has said the illustrious chief of the philosophical school of France, Etienne Geoffroy SaintHilaire, "we cannot fail, except when we cease to relate the truth." $\dagger$ Now, truth in science cannot be governed except by two means, reasoning after the manner of mathematics, and observation, of which experiment is but a variety. Every idea a priori, every hypothesis is only good if we accept it with a strong determination of abandoning it if the facts are no longer explicable by its means. Without this, its influence is dis-

* "All monogenists," we said in the first edition of this book. M. de Quatrefages has exclaimed loudly against these words (Unité de l'Espèce Humaine, 1861, p. 299), and in the same passage has shown himself an open enemy to all mingling of religion in the domain of science. We are too glad of this declaration not to recall it in this place. We should be sorry not to be able always to agree in these pages with the masters of science,-with those, indeed, who have been our own. We have been led to touch on several questions already treated of by them, by following another path, by looking at facts from another point of view; therefore, there are some differences of opinion. Our excuse lies in the universal right of free inquiry; for the rest, we shall always name the persons with whom we think we do not agree. "Not to do so," as Bayle said, "is in some measure an excess of ceremony prejudicial to the liberty which we ought to enjoy in the republic of letters; it is to introduce therein works of supererogation. It should be always allowable to name those whom we disprove; this is sufficient to prevent a bitter, injurious, or dishonest spirit."-Dictionnaire Philosophique, art. Pereira, note D.

+ E. Geoffroy Saint-Hilaire has not, however, been able to free himself completely from the unhappy influences which we endeavour to oppose. See Comptes rendus de l'Académie des Sciences, vol. iv, p. 78. 
astrous, let the origin of this previous idea be in ourselves or in others, whether it is our own or has been imposed upon us.*

In starting with a preconceived idea one arrives most often, in science, at false allegations, always at uncertainties. It is upon reasons of this sort that some have not feared to rest the theory of the unity of the human race; $\dagger$ since this hypothesis being accepted, they have caused, willingly or otherwise, their observed facts to correspond with it. Were the generallyadmitted principles of classification irksome to them? They passed on; they shut their eyes to the most profound, the most positive, the most evident differences. Ought not, then, unity to triumph? What did it signify, besides, whether the Negro descended from the white man, or the contrary-for these two opinions have been defended; for some, a few generations have been sufficient to transform the fine Greek blood, which gave models to Phidias and Praxiteles, into an Australian aboriginal. For others, the Negroes were the true representation of our first parents, that perfect work which last of all left the hands of God. Lieut.-Colonel H. Smith would admit that in the beginning were created separately certain groups of men, if revelation were not positive on this point. We notice especially in Kaempfer a specimen of what we may call orthodox ethnology, which is curious above all things; having discovered that the Japanese have nothing in common with the Chinese, he decides, with a marvellous assurance, that they are directly descended from the men on the scaffoldings of the Tower of Babel. And as their language resembles no other tongue, he draws the conclusion that their

* "It is too evident," says a modern philosopher, "that in the eyes of science, which, reasoning about discoveries, makes a rule to admit nothing as a theory which cannot be proved by experience, the agreement of faith with reason is a chimera : to speak more exactly, such a problem does not exist. The conditions of science are the observation of facts, -not of facts exceptionally produced, seen by chance, noted by privileged witnesses, and unable to be reproduced at will; but constant facts, placed under one's hand for observation, and always able to be verified. We must consider that religion can in no way submit to such exigencies, and that the faith which it proclaims must be, in this light, radically inconsistent."-P. J. Proudhon, De la Justice, vol. ii, p. 309. See also on this subject, L. Fleury, Le Progrès, 1858, No. 4, p.92. De Jouvencel, Bulletins de la Société d'Anthropologie, May 2, 1861.

† See Bertillon, Bulletins de la Société Anthropologie, June 18, 1863.

\$ The Natural History of the Human Species, 1848, p. 40. 
ancestors must have travelled very fast, so as not to have become acquainted with anybody else!*

And let no one say that it is obsolete matter to treat of science. Orthodox physics and chemistry are indeed no myths. M. Marcel de Serres, who has also occupied himself with anthropology, speaking of the discussions which have been raised between the partisans of emission and those of luminous undulation, adds, that this latter theory has more chances of being exact, "because the facts related by the legislator of the Hebrews seem to him to be more favourable to truth." $†$ The Congregation of the Index, judging Galileo, reasoned in the same way. $\neq$ We arrive thus at once at the proscription of certain inquiries, and we ask ourselves, How two men, so eminent as Humboldt and Bonpland, could have approved of such lines as the following? "The general question of the first origin of the inhabitants of a continent is beyond the limits prescribed to history, perhaps it may not be even a philosophical question." § It is true that the work in which this singular declaration is to be found is dedicated to his Catholic Majesty Charles IV.

Thanks to these fatal influences, thanks to the interdicts with which some would have desired to stifle the natural history of mankind, as if they were afraid of seeing the spark, which should accomplish the ruin of the past, disappear with the full light; thanks to.all these obstacles, anthropology was for a long time thrown into the background.

It is in America where we behold it reinstated in its rank, in that country of every kind of liberty. It is there that our old continent ought to go in order to find masters who have known how to enter into scientific pursuits with this free and

* Kaempfer, Histoire Naturelle, etc., du Japon, Lahaye, 1729, vol. i, p. 75.

† Marcel de Serres, De l'Unité de l'Espèce Humaine: Bib. Univ. de Genève, new series, vol. liv, 1844, p. 145.

¥ "The doctrine attributed to Copernicus," said the declaration made by the Pope, and published by the Holy Office, "that the earth moves round the sun, and that the sun remains motionless in the centre of the world without moving either to the east or to the west, is contrary to Holy Scripture, and consequently, can neither be professed nor defended."-Biot, La vérité sur le Procès de Galilée, in the Journal des Savants, July 1858, p. 401.

$\S$ Essai Politique sur la Nouvelle Espagne, vol. ii, p. 79. 
independent mind which, in old times, according to Epicurus, freed mankind from the yoke of superstition, and gave to intelligence the sceptre of the world.

The eighteenth century, with all its scepticism, had not done little in this way; its fault, indeed, was in this scepticism, in this doubting à priori. It rejected without examination, therefore its work was not lasting, and the few lines of Voltaire which his good sense had written with a Polygenistic tendency, had no influence at all.*

At present France and England walk entirely in the scientific path opened by the American school. It is some years since it was vainly endeavoured to establish in these two countries learned societies for the study of ethnology; that time has passed. Now Paris and London maintain two prosperous anthropological societies. $\dagger \mathrm{We}$ do not hesitate in attributing the reason of this success to the profound discredit in which the continued blending of matters of faith with matters of science, has justly fallen.

Apart from religious influence, there is another which may make itself felt as regards anthropology. We mean those very honourable sentiments about equality and confraternity which an honest heart will feel towards all men, whatever may be their origin, whatever the colour of their skin, but of which the searcher $\ddagger$ after truth must disembarrass himself, cost what it may to him as a man. Such feelings honour those who are animated by them, but when they interfere with science, they can only injure it. How many years, how many centuries, have anatomy and medicine been obliged to wait until they could take a lasting and an upward flight! Respect for the dead is doubtless a human sentiment, if any; but it used to paralyse these two branches of our knowledge ; they are only possible to be learnt by profaning mortal remains

* Essai sur les Mceurs: Introd., § 2.

† There is an idea of adding to the Linnean Society a new section of Anthropology.-See "Letter from E. W. Brayley," Medical Times and Gazette, p. 491, May 10, 1862.

I Alphonse Karr was the first who proposed to substitute the name of "searcher" (chercheur) for that of "learned man" (savant).-Nouvelles Guêpes, February 1859. 
reverenced by the religions of antiquity. Physiology, rendered so clear by vivisection, knows no pity; mankind feels it, but the physiologist shuts up all knowledge of it from himself; it is momentarily destroyed, since it would injure any inquiry into the laws of life.

It "must be owned that the science which engages our attention has not been able entirely to disembarrass itself among us of that which we may call moral propriety.* It has a powerful influence on certain minds, sometimes unwittingly, sometimes of their free will. $\dagger$

We have ourselves heard eminent professors make a noble appeal to the fraternity which ought to exist among men,plead in their chairs the cause of inferior races, and proclaim the equality of the African people with ourselves. Such noble theories were received as they ought to be, with the most ardent applause. There remains only to inquire if this is truly philosophical progress, and if kindness, pity, or compassion, have any value in the great balance of facts.

It was time, indeed, that a new method-an independent one-should see the light in anthropology, as it has already done in astronomy, as it also has begun to do in geology. It was time to return to the human mind its wings. Facts, reasonings supported by facts, are the sole basis of every solid work-of every certainty in scientific matters; it is the only method which can lead us-by a slow path, perhaps, but a sure one-to the solution of the most difficult and the most obscure problems. We do not except that of the origin of man.

We do not pretend to be first in the path which we here point 'out, but we wish to express our regret at not having seen it openly enough followed by all those who are worthy to enter it. As for ourselves, what we have desired in this essay is, first, to hold ourselves apart from all extra-scientific data -from all sentimental science; we have desired to treat some anthropological questions as they would have done at

\footnotetext{
* See, for example, Pucheran, Considérations Anatomiques sur les Formes de la tête osseuse.-Paris, 1841 ('Thesis).

+ M. de Serres, in his Lectures on Anthropology, at the Jardin des Plantes.
} 
Athens, Rome, or at Alexandria-a task above our powers, doubtless, but which we hold ourselves bound in honour to attempt.

We shall carefully, then, avoid entering into any controversy touching the dogmas of one religion or the other; we shall not contest the authority of the Scriptures, whatever they may be, Hebrew, Christian, Arabic, or Buddhist; we have put them on one side, and that is all.* Descartes has truly observed that every scientific question ought to be examined, even those which are most superstitious and most false, "so as to recognise their just value, and to guard against being deceived by them." + One may be free to consider this essay as an attempt of that kind.

We shall be praised or blamed: we have been so already. We have, for our comfort, the conscientious feeling of having no other object before our eyes but an inquiry into truth,the truth, the common end towards which the power of every man who believes in progress should tend. "Where truth reigns," says M. Chevreul, "no disputes or discussions are possible." $\ddagger$ The reign of truth is the reign of concord amongst mankind. It is the golden age.

* P. J. Proudhon has said, in another arrangement of facts depending on social science, "Revolution is not atheistical; it does-not deny the absolute, it removes it altogether" (De la Justice, vol. ii, p. 301). See, for fuller development of our ideas on this subject, the Progrès of the 20th of May, 1859, article on Science et Religion.

+ Discours sur le Méthode.

$\ddagger$ Lettres à M. Villemain sur la Méthode, Paris, 1856, p. 3. 


\section{CHAPTER I.}

THE HUMAN KINGDOM.

ABove inorganic matter, plants, and animals, is placed Man.

Here, without any doubt, man is indeed the first of the organisms, when one tries to place in linear series all those which move on our planet. It is, also, not his relative position in the living world that it is difficult to discover; it is what we may call his true place. What is, in other terms, the value of the differences which separate man from other mammalia? and at what distance is he from the animal that immediately follows him in this linear series which we are supposing? To examine what man is with respect to the highest orders of mammalia, and in a more general manner, to animals, is the primordial question which presents itself in anthropology. It seems at first sight that it would suffice, in order to settle it, to throw a glance on this complete body, formed of the same anatomical elements, absolutely submitted to the same exigences of development, nutrition, and reproduction, as animals. Ought not all this to make us think that we were not altogether made of so immaterial a substance as the philosophers have generally been satisfied to believe? This has not been the case.

Two systems-two theories, are before us. The one pretends that man is but the first among animals, that he is similar to them in the clear and precise sense in which this term is taken in geometry, designing qualities, which may differ ad infinitum, but which still may be comparable.

Another system, supported by the most illustrious names, makes of man a sort of special entity, differing from other organised beings by the distinct and clear nature of his intelli- 
gence. - It is an opinion adopted and defended to the last by a learned man, to whose momory we cannot, on passant, prevent ourselves from rendering the homage which is his due, Isidore Geoffroy Saint-Hilaire. We find in the second volume of his Histoire Naturelle Générale, almost a roturn to Cartesian ideas. According to him animals do not think, they possess only that sensibility that plants have not.* And the celebrated naturalist agreed with the adoption of a human kingdom, appearing as the crowning-point of the organic and inorganic kingdoms, + and as distinct from the second as this is from the third.

Before proceeding further, we may bo permitted to make one preliminary remark. We máy thus declare it:-

Proposition.-Man nearly approaches the Anthropomorphous Apes in his Physical Organism. Whether one is a partisan or not of the "Human Kingdom," this resemblance is a fact which it will be in no person's ideas to contest. And it is not merely in the external forms; we find it even greater if, going to the foundation of the facts, we give our attention to the essential parts composing the body, - to the anatomical elements,- to those delicate particles visible only in the microscope, and which always show, among animals of the same group, a marvellous uniformity.

It is here where, if not an impossibility, at least a sort of contradiction presents itself to the defenders of the "human kingdom ;" for there are two organisms, scarcely different, at the service of two directing powers, of two intelligences absolutely and radically dissimilar. Doubtless all the forces of organised matter are not known to us, but does not this resemblance, though evon a superficial one, surprise us; and does it not seem that every organism constituted directly by reason of the influences which it is qualified to receive or to

* See these ideas categorically explained, vol. ii, p. 281.

+ M. de Quatrefages admits a sidereal kingdom; and such a thesis seems to us a very difficult one to sustain, after the experiments of Bunsen and Kirchoff on the chemical composition of the stars. M. de Quatrefages admits also a human kingdom; but admitting that animals think, ho makes morality and religion characteristics of this kingdom. Unité de l'Espice IIumaine, 1861, p. 30. We shall have occasion to revert again to these two points. See Bert., Bulletins de la Société d'Anthropologie, August 7, 1862. 
transmit, ought to vary like these influences, and in the same proportion?

It is very easy to admit that there is more distance between the intelligence of man and that of the anthropomorphous apes, than between the intelligence of these last and that of the smooth-brained squirrel, and that at the same time the immense distance is only marked in the first case by very superficial variations of the organ of intellectual manifestations, whilst, in the second case, this lesser distance is explained by enormous differences.

To admit, with Bossuet,* that this superior intelligence, the appanage of man, is not attached to the organs reserved for the manifestations of this inferior intelligence common to man and animals, is to return to Descartes, and this is to fall again into new difficulties. Will this superior intelligence, thus detached from the material world, be then inaccessible to physical violence?

Whilst the finger of the physiologist or the surgeon, pressing the brain, extinguishes for a moment in the animal, the faculty of thinking, will human intelligence, freed from this servitude, remain, in the like case, undisturbed in a higher sphere? No, by the compression of the brain man loses consciousness like the animal. It is material substance, which, brought into contact with the anatomical elements of the nervous centres, can excite, $\dagger$ trouble, $\ddagger$ or depress, $\S$ the intelligence of animals, and leave no part of the human intellect untouched.

Let us reconsider these two systems: viz., that man is similar to animals as much by his intelligence as by his bodily formation; or that he differs from them entirely. And now we have two clearly stated theories before us for our consideration. To embrace either one or the other it priori, merely for the sake of propriety or sentiment, would be an arbitrary proceeding, essentially faulty, and contrary to all rule; as in

* See Is. Geoffroy Saint-Hilaire, Histoire Naturelle Générale des règnes organiques, vol. ii, p. 252.

+ Certain essential oils, like those of coffee, tea, or hemp.

I Alcoholic liquors.

$\S$ Narcotics: 
natural science, no other assistance is required except facts,.in order to explain the origin of anything. However, without prejudging the solution of this question, let us simply examine the results to which, by its nature, it may lead us. That man is of himself a special entity, a kingdom, a world of his own, a sort of microcosm, a whole beyond the pale of universal life, may be perhaps a flattering unction to our soul;* it does little or nothing for science. Anthropology may have its special means of inquiry; perhaps these means are still to be found, but she will stand alone-without profit to the other branches of human knowledge, a dead branch which will not grow, casting all its leaves. If not-if man enters into the common course of life-if he is merely a part of one grand organic whole, necessarily allied to others by a thousand points of contact and intimate relations, then anthropology, fertilised by the principle of universality, becomes a science by which we may profit; it gives to her sisters, the other natural sciences, that assistance which she herself receives from them; the paths widen; the science of organisation becomes easier, more certain, and more enlarged; synthesis, displaying its powerful energies, opens to us the path of the unknown; the mind, overleaping this obstacle, pointed out by Montaigne, "of not understanding" animals, will study their intelligence, and will search their inmost thoughts. As for ourselves, we are learning to know them, like Galen the inspired, who obtained a knowledge of human anatomy by dissecting a monkey.

Let us endeavour to obtain an exact idea of this barrier, apparently impossible to be overcome, which separates man from the brute creation. Whether we compare him to the highest order of primates living on trees-this genius

* "If I am not mistaken," says M. de Quatrefages, " there is in this result, independently of the scientific consequences which may proceed from it, a something which responds to our most noble aspirations. Man confers upon himself dominion of his own will; he loves to proclaim himself legitimate sovereign of all things on the surface of this globe; and, in fact, no creature will dare to dispute with him an empire which, day by day, extends and increases. Well! is it not satisfactory to behold anthropological characteristics sanction and ennoble this empire by placing by the side of the right, which springs from intellectual superiority, the notion of $d u t y$, which arises from morality and religion? (Unité de l'Espèce Humaine, p. 33.) 
which is the glory of humanity, which has raised to such a height both science and art-or only to the last from among us, members of the great family rejoicing in a white skin, then the transition is brutish, and it seems that an abyss separates us from the famous wild man of the woods, so celebrated in the travels of the last century. It is thus that the human kingdom has been established, comparing the two extremes, without taking account of the intermediate terms.

Let us put on one side, for an instant, the question of origin. A race, or a family, endowed with a characteristic and united activity, by the form of mind peculiar to itself, with a prepossession for reuniting in a cluster the work of every individual intelligence, forms out of it a sort of thought common to all, and transmits this inheritance from generation to generation. One can understand that, as time goes on, this family, or this race, will arrive at a degree of civilisation very different to that which it showed at the time of its origin. The concurrence of so many intelligent modes of action will gently, but naturally, lead it to purely metaphysical ideas-to the intricate idea of a divinity, etc. But, in such an arrangement, each one is, after all, but the representative of a secular intellectual work, accustomed since the cradle, without any self-knowledge of the fact, to natural habits and language. We ask if it is right to compare a being thus raised and exalted by his own means with an animal which has no more remote past than its own birth?* Let us take, then, for the sake of comparing them with animals, those people in whom life is in some sort individual, among whom no person adds anything to transmitted inheritance,-among whom even this inheritance has originally come from outside, and who, we know not why, having arrived at the lowest ebb of civilisation, have not been able to improve or perfect it.

Some may say that they simply copy everything. Some may say that the huge weapons used by the inhabitants of Central Africa and Australia have only become known by

*. Courtet de l'Isle has already made this remark. (Tableau Ethnographique du Genre Humain, 1849, p. 8.) 
importation; that the savage is civilised at a given moment by contact with some foreign nation-by imitation, a faculty which is possessed, within well marked limits, by the highest order of apes ; and then, that progress has been stopped when these people return to their own homes. How can we explain otherwise, for example, that the Northern Esquimaux, living on the ice by the borders of creeks and bays, can make dresses and arms, and have never been able to construct a machine capable of bearing them upon the waters ?*

If we break up one continuous series, and compare together the two first terms with two of the fragments of the series, they will in reality appear entirely distinct; in fact, almost impossible to be connected with one common type. But, if we compare the last term of one of these partial series with the first term of the following, then the differences are blended, because the transformations do not happen to hide the parts so much that one cannot recognise their fundamental unity. We discover, for example, that in the animal series, such 'a crustacean is almost a mollusk, such a reptile, such a mammal, almost a bird.† Differences are extinguished; those beings which were said to be most distant have become almost allied one to the other. We can only perceive one continuous series; so much so, indeed, that even where there are any unfilled spaces, or missing links, we consider ourselves almost justified in declaring the past existence (or the future one?) of some intermediate animal.

As for ourselves, the series of beings given by Bonnet and Leibnitz, so far as regards any ulterior phenomenon, resulting from the observation of beings who have not been of necessity created in this order, is true not only of the physical, but also of the intellectual world. Shall we desire to know what man has in common with the ape-what distance there is between the one and the other,-let us no longer put ourselves on the stage, we who are privileged so to do; let us descend boldly

\footnotetext{
* See the Voyage de l'Isabelle; also Desmoulins, Histoire Naturelle des Races Humaines, 1826, p. 276.

+ Cirripeds, tortoises, ornithodelphi, and generally speaking, the extreme representatives of the divisions of each natural classification.
} 
the steps of the human ladder, and let us see what we shall find as we do so.

Examples are not wanting of races placed so low, that they have quite naturally appeared to resemble the ape tribe. These people, much nearer than ourselves to a state of nature, deserve on that account every attention on the part of the anthropologist and the linguist, who may both discover, by their means, problems otherwise difficult or impossible to be solved. It is because we have not studied the psychological characters of these races, that we have fallen into such strange mistakes. What will become of all those superb theories concerning this superior intelligence of man, so entirely independent and disengaged from the world, on which so much praise is conferred? What will become of the unity of the human species, if we can prove that certain races are not a whit more intelligent than certain animals, and have no more idea of a moral world or of religion than they themselves have?

The most commonly quoted example is that of the aborigines of Australia. "They have always shown complete ignorance," say both Lesson and Garnot,* "a sort of moral brutality. . . . A kind of highly developed instinct for discovering the food which is always difficult for them to obtain seems, among them, to have taken the place of most of the moral faculties of mankind." If the English police did not watch very strictly, they would set at defiance every day, at least in the towns of their colonies, all the laws of public decency without any more thought than the monkeys in a menagerie.

In the account given of the American Expedition in 1838, Mr. Hale writes that they almost possess the stupidity of the brute, that they can only count up to four, and some tribes only so far as three. "The power of reasoning," he says, "seems but imperfectly developed among them: The arguments used by the colonists to convince or persuade them are often such as they would use towards children or persons

* Mémoire sur les Tasmaniens, sur les Alfourous, et sur les Australiens, in the Annales des Sciences Naturelles, 1827, vol. x, p. 155. 
who are almost idiotic."* MM. Quoy and Gaimard, whom no one will accuse of polygenist tendencies, give the following account of their interview with these miserable people. "Our presence seemed to cause them a sort of pleasure; and they endeavoured to explain their sensations on the subject with a loquacity to which we could not respond, seeing we did not understand their language. After this meeting they used to come to us, gesticulating and talking rapidly; they gave shrill screams, and if we answered in the same way, their delight was immense. Soon there was a change, and they did not hesitate to ask for something to eat, by the simple mode of hitting themselves on the belly." $\dagger$ The spectacle these travellers had before them is so sad and touching that they afterwards add, as ,if to satisfy their own consciences, "however, they are not stupid." Doubtless, they are not; but they do not seem to deserve the epithet which the world gives to these beings, who appear so completely inferior to others. "Malicious as a monkey." They are not stupid, and that is all. The Australians are not exceptional in this; Bory de Saint Vincent has drawn for us a picture of the inhabitants of South Africa, a beautiful and fertile land, which is almost as sad. At the other end of the world, upon that ice-continent which surrounds the north pole, we find the same abjection.

Sir John Ross, lost among the ice, found himself among a race of people who had never seen an European; this English sailor, a strictly religious man, was peculiarly adapted to behold with indulgence the only beings who were near him, but although he was an attentive and scrupulous observer, and above all, a truly sincere man, he seemed to despair of finding in their minds the living spark for which he was searching. "The Esquimaux," he

* Hale, Natives of Australia, etc. See American Journal of Science, second series, vol. i, p. 302, May 1846 ; extract from the account of C. Wilkes' Expedition: Narrative of the U. S. Exploring Expedition during the years 1838-1842, vol. vi, "Ethnography and Philology."

† Voyage de l'Astrolabe: Zoologie, vol. i, p. 43.

\# Even after the assertions of M. de Quatrefages in the Unite des Races Humaines, p. 162, and following, we have not thought ourselves justified in changing our opinions on the subject of the Australians, which have lately been confirmed at the Anthropological Society; a Mr. O'Rourke, an eyewitness, having answered M. de Quatrefages (Bulletins de la Société d'Anthropologie, 21 June, 1860). 
says, "is an animal of prey, with no other enjoyment than eating: and, guided by no principle and no reason, he devours as long as he can, and all that he can procure, like the vulture and the tiger."* And, farther on, "The Esquimaux eats but to sleep, and sleeps but to eat again as soon as he can." $†$ We shall descend still lower, in order to find out men who are so degraded, that those who have seen them have stated, that if they were in thick bushes or the shadows of the forest, they would hardly have known whether they were apes or men. And, let attention be paid to this,- - these wretched beings, almost deprived of human form, do not inhabit a pnor or secluded country, but the continent of Asia, to the south of the Himalaya chain, in the centre of Hindoostan, in those regions which have been the cradle of several huge species of apes, at that epoch, doubtless, when the islands of the Indian Archipelago were joined to Asia, and formed one immense continent,- - the land of the Malay race. $f$

In 1824, an English colonist, Mr. Piddington, a settler in the centre of Hindoostan (towards Palmow, Subhulpore, and the upper basin of the Nerbudda), relates $\S$ that he saw amongst a party of Dhangour workmen,-who came every year to work on his plantation,-a man and a woman who were extremely strange and uncouth, and whom the Dhangours themselves called monkey-people. They had a language of their own. From so much as could be understood by signs, it was discovered that they lived far beyond the country of the Dhangours, in the forests and in the mountains, and possessed few villages. It would seem that the man had fled with the woman in consequence of some misfortune, perhaps a murder. But at all events, they were found by the Dhangours lost in the woods, exhausted, and almost dead from hunger. They disappeared suddenly one night, just as Mr. Piddington had

* J. Ross, Narrative of a Second Voyage, etc., 1835, p. 448.

+ J. Ross, Narrative of a Second Voyage, p. 490.

I See Étienne Geoffroy Saint-Hilaire, Comptes Rendus, vol. v, p. 42. [We should very much like to know at what period our author imagines this to have been the case, and whether he considers that these apes were the "men of the day."-EDiTor.]

$\S$ "Memorandum on an Unknown Forest Race," etc., Journal of the Asiatic Society of Bengal, 1855, vol. xxiv, p. 207. 
made arrangements to send them to Calcutta. It would seem from other information that a Mr. Trail, for many years Commissioner at Kuman, had also seen these extraordinary beings, and had even been so fortunate as to procure one of them, whose appearance fully justified the traditional name given to them by the natives. In fact, other evidence-some of it historical - may be added to this in order to prove the existence of such an inferior race in different parts of the Indian peninsula. $\mathrm{Mr}$. Piddington thus describes him:- "He was short, flat-nosed; had pouch-like wrinkles in semicircles round the corners of the mouth and cheeks; his arms were disproportionately long, and there was a portion of reddish hair to be seen on the rustyblack skin. Altogether, if crouched in a dark corner or on a tree, he might have been mistaken for a large orang-utan." It must be noticed that Mr. Piddington had travelled a great deal, and that he had acquired, even without his own knowledge, some experience in anthropology. He takes care to tell us that he had seen in their turn the Bosjesmen, the Hottentots, the Papous, the Alfourous, the aborigines of Australia, New Zealand, and the Sandwich Islands, which, indeed, gives great authority to the facts which he relates.* What, we may indeed exclaim, are these really men? After journeying over the beaten track, see how far we are from that Aryan family, the mistress of arts and science; how much we approach the brute, even if we have not already reached that point? We have descended; let us now raise the other mammalia to man, and in the highest degree to which we can attain, let us endeavour to measure the distance to the point we have just left. Let it be well understood; we shall only consider in this place the highest mammalia ; for the question becomes more complicated on every side as soon as the difference in the organisms becomes more apparent. In regard to this, facts have often spoken for a long time, and the savant, whose testimony in

* M. Ehrenberg, speaking one day of the unknown centre of Africa, said to us, "that it might not be impossible to find there men so different from us that we ought to make of them, willingly or unwillingly, a special group." I quote these words in no way with the design of presuming that there is such an order of beings; but in order to show that the father of the naturalists of Europe, the friend of Humboldt, believes in something else than the unity of the human species, because he admits that a generic plurality is possible. 
such a case possesses most value, Professor R. Owen, has not feared to say, that the distinction between man and certain primates is the great difficulty felt by all anatomists.* Let us pass on to intellect.

All animals feel, understand, and think (M. Flourens and M. de Quatrefages), they dream, are capable of feeling distrust, fear, joy, $\uparrow$ sorrow, jealousy, etc. ; in fact, the entire list of human passions.f All this is amply proved by a thousand examples; who does not remember the accounts of seals, elephants, dogs, which have become celebrated, and which men who have lived a short time with animals may see repeated every day? Only read the admirable account given by Buffon of the intelligence of the dog; again, the detailed and valuable history which $\mathrm{F}$. Cuvier has left us concerning the orang-outang in the Museum, without forgetting that this history could be neither complete nor perfect on account of the various circumstances in which the animal was placed, far from his own country, and under an ungenial sky.

Dr. Yvan, attached to the expedition which the French government sent to China in $1843, \S$ has given us an account of an orang-outang at Borneo, which is, perhaps, the best plea in favour of the connexion between primates and mankind. Tuân, as this animal was called, began to dress himself directly a bit of any stuff, or cloth, got in his way.\| On one occasion, when his master had taken a mangrove from him, " he uttered plaintive cries like a child when it is sulky. This

* R. Owen, On the Characters of the Class Mammalia, 1857, p. 20, note. The illustrious savant has himself treated on this subject, ex professo, in the catalogue of the collection in the College of Surgeons.

+ "The orang-outang is capable of a kind of laugh when pleasantly excited," J. Grant, "Account of the Structure of an Orang-Outang" (Edinburgh Journal of Science, vol. ix, 1825).

I Artificial love itself, with all the complexity of ideas which it is supposed must thence arise, is not, as one may think, the debauchery of civilisation; it belongs to animals akin to man as well as to man himself. See Ch. Robin and Béraud, Précis de la Physiologie de l'Homme, vol. ii, p. 384. It is the same with impure connection, or coupling, radically inexplicable by instinct. See Isidore Geoffroy Saint-Hilaire, Histoire Naturelle Générale des Règnes Organiques, vol. iii, p. 142.

$\S$ Doctor Yvan commanded the Archimedes; he has written an account of his voyage: Voyages et Récits, Brussels, 1853, 2 vols. in $12 \mathrm{mo}$.

|| "The Australians only wear woollen clothing in order to protect the chest; . . no idea of shame has ever led them to hide the natural parts." Lesson et Garnot, Annales des Sciences Natuvelles, 1827, vol. x. 
conduct not having been so successful as he expected, he threw himself on his face upon the ground, struck the earth with his fist, screamed, cried, and howled, for more than half-an-hour.". When the mangrove was given back to him, he threw it at the head of his master.* It is a curious fact, but the particular friend of Tuân was a negro from Manilla. At Manilla, he accustomed himself to Tagal $\dagger$ manners, and played with the children. "One day, when Tuân was rolling on some matting with a little girl, about four or five years old, he stopped all of a sudden, and examined the child in a most minute and anatomical manner. The results of his investigations seemed to astonish him profoundly; he retired on one side, and repeated upon himself the same examination which he had made on his little playmate." We may all remember the eloquent pages in Buffon, where, admitting the Adamic legend, he recounts the impressions of our first parents. Has not nature been here, we ask, a better historian than our naturalist, even with all his genius?

Over and above these facts, as their crowning-point, we must invoke as a witness the man who has carried farthest the spirit of philosophy in the natural sciences in France, Etienne Geoffroy Saint-Hilaire. A cautious and profound observer, he mingled with the crowd which the orang drew to the Museum in 1836. Mistrusting his own judgment, he gathered the opinions of all those who surrounded him,-of all the visitors who, as he said, "came to observe as unprejudiced spectators, without any preconceived ideas, and without being hindered by those deplorable trammels which we call our rules of classification." $\ddagger$ The result surprised even Etienne Geoffroy himself. These visitors, so different one from the other, all united in this idea, "that the animal from Sumatra was neither a man

* The orang observed by J. Grant also showed these signs of desperation ; "he poured it (a saucer) angrily out on the floor, whined in a peculiar manner, and threw himself passionately on his back on the ground, striking his breast and paunch with his palms, and giving a kind of reiterated croal." - "Account of the Structure of an Orang-Outang," Edinburgh Journal of Science, vol. ix, p. 11. [The same demonstration of feeling was showed by the orangs in the Zoological Gardens, May 1864.-EDitor.]

+ [Tagal, a chief town of Java.-EDitor.]

I Comptes Rendus de l'Academie des Sciences, vol. ii, p. 582. 
nor an ape: neither one nor the other, that was what the mind of each person at once acknowledged."

We might quote whole pages from this naturalist philosopher in which the elevation of his style strives with the grandeur of his ideas. "I never used my self-love," he says, "in bringing forward other opinions against those of the visitors to the orang-outang . . . I never drove back the torrent of information which I had the happiness of receiving from each separate mind. . . . I have faith in the soundness of popular opinions, the masses rejoicing in an instinctive good sense which makes them clear-headed, and renders them peculiarly able to seize the salient point of any question." This was an excellent method, and showed the power of Etienne Geoffroy SaintHilaire.

It is curious to compare with him another writer who, from within his study, invoked upon these questions, at least, that which we may call universal acquiescence,-it is Maupertuis. Speaking of the characteristics which make man different from animals, he says, "Simple good sense seizes these differences; they have always been felt, and there we behold one of those convictions which the universality and uniformity of all men characterise as the truth."*

Maupertuis did not certainly know that the orang-outang,a word which means wild-man,-is no metaphor for the inhabitants of the Indian Archipelago, and that in the country inhabited by the "long-nosed" Guenon, the popular belief is that, being sharper than the others, he only keeps silent in order to preserve his liberty. Nothing can be more fallacious than these pretended truths, sustained merely by universal acquiescence. At first it was invoked as a proof, at a time when scarcely onetenth of the inhabited world was known : $\neq$ but let us proceed. In our own day, we know a little better what to make of this kind of proof, which science has abandoned to theologians. Experience has proved, day by day, what will become of this pre-

* Essai Philosophique sur l'âme des bêtes, 1728, p. 132.

+ [Guenon, the Simia nasalis of Buffon.-EdiTor.]

‡ Plato, Leges, x, 1. See Maury, Religions, vol. iii, p. 4, note 2. 
tended universality among mankind, of certain thoughts, certain sentiments, and certain aspirations.*

We shall see, farther on, that the community of some of those intellectual manifestations, which many have wished to regard as general, is often restricted to one race alone amongst mankind, and limited in space by the boundaries of the continent occupied by this race. And now we see how anthropology in her turn, can, in all these points, assist even philosophy itself. For example, do we not feel that, from henceforward, the words beautiful and right can mean nothing absolute; since whatever is beautiful and right upon a hemisphere, for any given intelligence, cannot be so in an opposite hemisphere,cannot possibly be so in a mind otherwise formed and belonging to another race. To these two words we must, by means of anthropology, restore an exclusively relative value. $\dagger$ The True alone is absolute, unchangeable in both time and space. That alone reigns universally, and let us not forget this, it flourishes in science alone,-it is only to be found there. $f$

* After having said that the idea of good and evil (moralité) exists among all men, M. de Quatrefages adds, that "the notion of the Divinity and that of another life are also generally diffused" (Unité de l'Espèce Humaine, p. 23). We shall demonstrate further on (chap. $v$ ) that this statement is incorrect, and how fragile the bases are upon which M. de Quatrefages rests the fundamental characteristics which, according to him, distinguish the human kingdom.

+ M. Chevreul has already defined the "Beautiful" as "the expression of causes whose influence has most force in moving mankind by appealing to their senses" (Lettres d M. Villemain sur la Méthode, 1856, p. 169).

I ["Truth lies at the bottom of a well," is an old saying, but our author does not seem to agree with it. We should be very sorry to think that truth was only to be found in science. This is, doubtless, the opinion of a great many learned men at the present day; but we must candidly own we do not agree with it, and certainly are not able to endorse $\mathbf{M}$. Pouchet's sentiment. We have ourselves not arrived at the point, and in this we are, doubtless, old-fashioned, - of referring everything to "reason," as opposed to faith.EDITOR.] 
CHAPTER II.

\section{COMPARATIVE PSYCHOLOGY.}

ON one occasion, two monkeys were brought into the presence of the orang described by Grant, about which we spoke in the last chapter. They were led by a chain up to the animal, and were threatened with a stick. "During the whole interview," says our informant, "the grave commanding attitude and bearing of the orang, compared to the levity and apparent sense of inferiority of the monkeys, was very striking, and it was impossible not to feel that he was a creature of a much more elevated order and capacity.*

"The animal from Sumatra is neither a man nor an ape," said the crowd before the orang at the Museum. The communications which were then made to the Institute by Etienne Geoffroy Saint-Hilaire may be, one of these days, a new triumph for him, the forerunner of a science which is not yet in existence,- the study of intellect in animals, based upon observation and experience; as for instance, in the passage where he proposes to submit the orang to a methodical education, in order to study the modifications which would be caused by such an alteration of method. $\dagger$ He who has discovered organic unity, will have placed us in the way of a discovery not less important, that of psychological unity. $f$ A new science, which would

* Edinburgh Journal of Science, 1828, vol. ix, p. 10.

+ Comptes Rendus de l'Académie des Sciences, vol. iii, p. 29.

\$ We can compare this passage from the naturalist philosopher with the other quotations we made farther back. "Females are extremely curious about this spectacle (the fondness of a "mother" monkey for her young one), and doubtless their attention is caused by discovering therein a true manifestation of the feelings they have themselves experienced as mothers; they are, above all things, astonished to recognise in these ardent attentions the 
only date from the time of the reaction against Cartesian ideas, -a science still without a name, merely touched upon even by great minds which have the inestimable privilege of understanding everything; it has never been studied,-never thoroughly investigated,-never submitted to all our means of information.* We should call it Comparative Psychology.

We should, then, re-enter into one great Unity. The intellect of vertebrate animals would be identical, as their organism is identical; thus gradually descending, passing through the orang, from man himself to all the mammalia. It may be said that these propositions are not yet proved,- -at least it will be allowed, seeing what has passed during a very few years, that the last word has not yet been said concerning the intellect of animals.

Has this question, then, made so much progress, either to the profit of animals or the detriment of mankind, that we should wish to stop it, when it has started already on so straight a path? Saint Chrysostom reproached the Gentile philosopher, it is said, with having always been inclined to assimilate that which they called the soul of animals with that of man himself. $†$ The opinion of these Gentiles, nevertheless, is worth the trouble of being noticed. They were as well able to observe animals as ourselves. Since then, the means of study, as applied to intellect, have made little or no progress; observation and reflection are still the same; we have found no new process, no new method, by which we can more profoundly examine into this subject; we have, then, no reason to think that the solutions given by ourselves upon this point are at all preferable to those of the ancients. 'It may be rather the contrary. For their opinion has this much in its favour, that it was born free, in minds which did not restrain, even unwittingly, any new influence or theory which might be

joy and pride of maternity, of which they believed themselves alone to be susceptible" (É. Geoffroy Saint-Hilaire, Cours d'Histoire Naturelle des Mammifères, Paris, 1829, vol. i ; Lesson, vi, p. 16).

* Proudhon has already laid down as a principle the establishment of a psychology among animals (De la Justice, vol. ii, p. 279). Frederick Cuvier has done the same.

† Hom. iv in Acta Apostolorum. See Rechtenbach, De Sermone Brutorum, Erfurt, 1706, p. 1. 
brought forward.* The idea of the intellectual gradation from man to animals must have been necessarily offensive to Christianity, which promised a future existence; it was not so for these Gentiles, who were much more occupied with matters of the world. $\dagger$

The principles which we are endeavouring to revive are not, however, completely those of Aristotle. In his treatise on the soul he admits this gradation, but as presenting in each degree a new manifestation beyond the manifestations existing in the inferior degrees. The principle of the soul is unity; but as we reascend the series, from plants to man, it invests itself with a greatly increased number of faculties. Porphyrius, resuming the ideas of the Stagyrite, seems to go even further, and to approach nearer the truth; it is not faculties joined one to another that he recognises in man and animals, but the same in all, only more or less developed. $\ddagger$

At the present day, if we have not returned to the ideas of Pythagoras and the Stoics, at least we are very far from Pereira and Descartes, with their animal machines, hydraulic-pneumatic machines, as one of the partisans of the Bréton philosopher (J. H. Crocius) calls them. $\$$

* Sometimes this restraint-is openly avowed; and we see M. Maire, who is also engaged upon the same questions, admit that, without these influences, he would embrace the same ideas that we are endeavouring to bring forward. "Let us frankly avow," he says, "if we had not continually before our minds the doctrines of a religion which we respect,-if we had not a sincere faith, this intuitive belief which tells us we must make a mistake,-we should dare to write thus. The more the organisation of the animal is perfected, the more the spiritual element produced by the action of the various functions is itself perfected. . . . There would then be only a hierarchical gradation of one and the same principle. The psychical fluid would be always the same in all individuals. The difference in its manifestations would refer to the difference in the organisations which produce them" (Société Havraise d'Etudes Diverses, p. 169, 1855 -1856.

+ [We cannot exactly see why it must necessarily have been offensive to Christianity. There is nothing injurious to religion in the theory of intellectual gradation.-EDIToR.]

I Jam vero nobis ostendendum est eam (bestia) habere rationem internam et intus conceptam. Videtur sane a nostra differre, non essentia sed gradu. Uti nonnulli existimant Deorum a nostra discrepare rationem, non differentia essentiali, sed quod illorum magis, nostra minus sit accurata. Et quidem quod ad sensum attinet et reliquam, tum instrumentorum sensus, tum carnis universæ, conformationem attinet, eam eodem nobiscum modo se habere in animalibus, ab omnibus fere conceditur.-Porphyrius, transl. by Holsteinius, De Abstinentia, 1655, p. 108. Is not unity of composition here conjectured, both for the intellect and the body?

§ Disquisitio de Animâ Brutorum, Bremæ, 1676. 
We are really astonished at the infatuation for the opinions of Descartes which took possession of Germany during the latter half of the seventeenth century. They were pushed to the extreme point,- - soul, reason, and intellect were denied to all animals. A person named Stahl,* who had at least the merit of being consistent to the last, brings forward a principle, that animals do not feel, bruta non sentire. This announcement is the conclusion of a very learned syllogism, and which one Gaspard Laugenhert had added to the Compendium Physicce of Arnold Geulinx.

It is with much trouble that some strong minds have dared to raise their voices in this Cartesian concert, having taken good care to strengthen themselves by plenty of quotations gathered from the Old and New Testaments. $†$ These were then proofs positive, and at times it was prudent to use them. The side of the animals has been successively strengthened by Buffon, and indeed by everybody. At the present day, M. Flourens refuses them thought alone, "this supreme faculty which the mind of man possesses, so that it may rely upon itself, and study its own mind. $\neq$ There is here," says the physiologist of whom we are speaking, "a strong line of demarcation; this thought which can reason about itself,-this intellect which beholds and studies itself,-this knowledge which is acquainted with itself,-evidently forms an order of determined phenomena of a clearly defined nature, and to which no animal would know how to attain. There is a purely intellectual world, if we may say so, and this world belongs only to man. In one word, animals feel, understand, think ; but man

* Logica Brutorum, Hamburg, 1697. This little treatise, in spite of the extreme ideas of its author, is not the less precious. J. Stahl was one of those wells of learning which Germany has so often produced. There is, perhaps, not one passage in the old authors who wrote on this point to which he has not referred in his work.

+ See, among others, S. Gros, De Anima Brutorum, Wittemberg, 1680; Klemnius, De Animâ Brutorum, Vittembergiæ, 1704.

$\ddagger$ Upon this point, M. de Quatrefages agrees with M. Flourens; but the distinction which he endeavours to establish, being based upon morality and religion, seems to us much more restricted and much less clear. Not being able to answer everybody, we have been obliged to attend merely to the opinions of that partisan of the human kingdom who gives to animals the largest portion of it. 
is the only one among all created beings to whom the power has been given of feeling that he feels, of knowing that he understands, and of thinking that he has the power of thinking."*

Such is the only difference. The question is now reduced to a more limited field than it has ever been before, and infinitely less vast. The thing which would be wanting in animals is a kind of internal knowledge ; not the knowledge of oneself (they know this since they feel) but the scientific knowledge of oneself, which can bring reflecting and reasoning study to bear on all the interior phenomena which may occur to each. We desire fully that this may be a distinction, but solely a secondary one, and able at most to make certain races of men differ one from the other. In fact, if we form an absolute and fundamental character of humanity out of this faculty, this power of investigation into an interior world, we ought to find it in a powerful manner among all men. It will resist every other influence, it will be permanent, since, this being destroyed, man would be no longer a man, and would be lowered by this fact to the rank whence he is said to have come.

And do we consider that it may possibly be so? Does this reflected knowledge of oneself exist among inferior races, if it does not exist among animals? Certainly we shall never maintain that these last enjoy such a faculty, the source of all our legislation, and that which has made us what we are. But we ask if it is well proved whether all human races possess it. If we do not allow innate ideas to the orang, as F. Cuviert would do, be it so, but let it be remembered that certain philosophers have refused them to man himself. We ourselves agree that an animal has no abstract notion of right or duty, or any idea of a divinity, $\ddagger$ but it must also be remembered that certain people have not even a word for the purpose of expressing these things, and it is M. de Quatrefages himself who avows it. $\S$ We refer these persons to the following account of animal

* Proudhon says, in language which is even more concise and affirmative, "In man, the mind knows itself; whilst elsewhere it seems to us that it does not do so"' (Système des Contradictions économiques, vol. i, 1850, p. 20).

+ Annales du Muséum d'Histoire Naturelle, vol. xvi, p. 58.

¥ Maire, Société Havraise d'Etudes Diverses, 1855-1856.

$\S$ Unité de l'Espèce Humaine, 1861, p. 24. 
economy, and we think that they will not deny their application to various African and Oceanic tribes. "Ideas, abstract ideas, arise from their own domain; the past, that which preceded their birth; the future, that which will follow their death, does not occupy their attention; the present is their only business in life. They do not demand 'Whence do I come? What am I ? Where am I going? And they have no idea whatsoever of a Divinity." "* Bayle, Maupertuis, $\dagger$ and M. Flourens have, one after another, declared how difficult it is to fix a limit, to say where the intellect of animals ceases, and where that of man commences. That limit escapes even ourselves; whilst separating two terms specifically distinct we only see one continued line from the other vertebrate animals to mankind, without any clearly defined demarcation,-the organism only of one mammifer as separated by an unbroken limit from the organism of another. It is a chain of which the links, if we wish, may go on increasing from one extremity to the other, following a given progression, but without ceasing to be like, and consequently comparable amongst themselves. A certain number of links may be wanting, but the mind re-establishes them, and the continuity, although an abstraction, is not the less real. It is even, if we may say so, the track of a hyperbolic curve, interrupted here and there, of which only the arcs remain, quite different, and all, however, reducible by the mind to one and the same system.

Unity of composition is the condition of all harmony, the necessary rule of nature. As to ourselves, we only see everywhere the same faculties, extended and developed among the superior vertebrate animals; having even acquired among mankind the singular property of aggrandising itself almost ad infinitum, confined among other vertebrata, enclosed in a small circle, where they can even escape our own means of knowledge.

But there is everywhere the same nature, everywhere things are alike. Life is unity; we do not share it one with another;

* Maire, Société Havraise d'Etudes Diverses, 1855-1856. We can make the same comparison with a passage almost similar from Maupertuis, Essai Philosophique sur l'âme des Bêtes, 1728, p. 134.

† Essai Philosophique sur l'âme des Bêtes, 1728, p. 95. 
both the life of the body and the life of intellect, both matter and the mind, and the organism and the faculties,* belong to each one separately. Terms correlative one to the other, never independent. There is an immense space between the intellect of animals and that of a civilised European; we willingly recognise this, but encumbered by mean terms and numerous transitions; that these latter exist, or that they have finished their time upon our planet, we also allow. The question of language, so confused, and so full of obscurity, still remains.

"Whatever resemblance there may be between the Hottentot and the monkey," says Buffon, "the distance which separates them is immense, since internally it is filled by thought and outwardly by speech." $\dagger$ We know how to consider the first of these appreciations. As to the second, let us see if we shall not there perceive a sort of gradation which would insensibly lead us from our own complicated languages to others of a much greater simplicity, so much so that they can scarcely be called by that name. Speech and language are two words often confounded, but in science we must give to each of them its own value. Speech is a language articulated by the respiratory channels. Language may be defined as "everything spoken by well known and understood means between two intellects." It may be seen that we give the fullest acceptation possible to this word. It is a language that the Abbé de l'Epée invented for the deaf and dumb. The writing of this language is another. A phonetic telegram is, as regards a stranger, merely a succession of sounds, like the song of a nightingale; a naval telegram is only an assemblage and a combination of colours like an arabesque, united the moment when the necessary arrangement forms these sounds or these colours into language. $\dagger$

Speech alone being the habitual and natural language of mankind, endowed otherwise with special organic specifica-

* See E. Geoffroy Saint-Hilaire, Comptes Rendus des Séances de l'Académie des Sciences, vol. iv, p. 261.

† See Flourens, Histoire des Travaux de Buffon, 1844, p. 135. Descartes made use of the absence of speech in animals as a strong argument against them.

‡ See Gratiolet, Bulletins de la Soc. d'Anthropologie de Paris, 18 April, 1861. 
tions in order to produce it, we have been generally led to confound these two distinct things in speaking of mankind, viz., speech and language. This being allowed, the first question which we have to examine is this, "Has man always possessed the faculty of speech ?" A difficult question, but one which we have no right to proclaim as impossible to be solved, which is, perhaps, not the case, and of which the difficulty belongs principally to the very imperfect knowledge which we possess concerning the distant epoch which saw mankind in his cradle.* Let us first of all remember that man has, in common with animals, voice, cries, natural inflections (M. Flourens), that which we otherwise call natural language. "Like a simple animal," says Herder, $†$ " man possesses the faculty of speech. All the most violent and painful sensations of his body, as well as the strong passions of his mind, are manifested immediately by cries or inflections of the voice, by natural and inarticulate sounds. The animal which suffers-as well as the hero Philoctetes-when it feels sorrow will moan and sigh, even when abandoned in a desert island, far from the sight of any friendly creature, without any hope of succour." This language is intelligible between all animals, between animals and ourselves, and between ourselves and animals. We may affirm that man possesses it always, from the first hour of his birth. As to articulated language, as artificial language has been called in opposition to the preceding, the question is much more confused and much less clearly defined.

We think with Steinthal, with Jacob Grimm, $\ddagger$ and with M. Renan, $\S$ that language is not innate in man, that is to say, it is not, as the Buddhist philosophy has already declared, a necessary consequence of active intelligence.\| Further, it has

* See J. Grimm, De l'Origine du Langage, transl., 1859, p. 53.

† Traité de l'Origine du Langage, Engl. transl., 1827, p. 6.

I De l'Origine du Langage, transl., 1859.

§ De l'Origine du Langage, znd edit., 1858.

II It is by tracing, according to custom, effects to their causes, that the Buddhist philosophy arrives at the principles of joint responsibility, which, according to it, unites reason to language, making them mutually flow one from the other. "Name and form have as a cause, intellect, and intellect has for a cause, name and form.--See Burnouf, Le Lotus de la bonne loi, p. 550. Mercurius Trismegistus, in the Pimander (Pimander, De sapientia et potestate $D e i)$, says almost the same thing: "Speech is the sister of intellect; intel- 
not been revealed-this theory does not even deserve the honour of having been opposed by Jacob Grimm.* But we may admit that language is, if not a necessity, a least a direct consequence of an intellect such as existed amongst mankind at the time, whether long or short we know not, which preceded the appearance of language.* "The moment," says M. Renan, stating the theories of Steinthal, $\uparrow$ " that language arises from the human soul and appears in the light of day and constitutes an epoch in the development of the life of the mind, is the moment when intuition is changed into idea. Things appear first to the mind in the complexity of the real, abstraction is unknown to the primitive man." Here, then, are two well-characterised modes, two ways of being, entirely different from the intellect of man. The one, where this intellect only possesses intuition, the other where analysis sees the light, where the mind is abstracted, and where, by a mechanism more or less complicated, but at the same time by a real work, $\ddagger$ it ends by calling every abstraction of mind by a name; then he speaks. But before the time when this revolution is accomplished, the state of man is completely comparable to that in which animals are placed. They have caught at certain relations by means of their intelligence, without usually feeling any necessity for explaining them, a relation of a much more elevated order of beings, for it has been truly remarked, $\S$ and it must not be forgotten, that the capital act of language is to "wish to speak."

We have seen that certain abstract ideas, by reason of their nature, were so entirely foreign to certain races of men, that their intellects had never wished for a word in order to express them. Well, if other ideas, expressing much more simple relations, have escaped animals, there is only, in fact, a gradation corresponding to what we have just said concerning intellec-

lect is the sister of language." See Rechtenbach, De Sermone Brutorum, 1706, p. 2.

* See De l'Origine du Langage, transl., 1859.

+ De l'Origine du Langage, 1858, p. 31,

I See Jacob Grimm, De l' Origine du Langage, transl., 1859, p. 29.

$\S$ Father Pardies (S. J.), in a work, otherwise of no great value, Discours de la Connaissance des Bêtes, 1672, p. 39. 
tual phenomena among the human race. As for the specific difference which some have tried to establish under this head between man and animals, if it were correct it must be shown that language is completely unattainable by any mammalia, even within the most restricted limits.

And is it so? Will it be mooted that certain animals have not even a rudiment of language, whether articulated or not it does not much signify, in their state of nature? Will it be mooted that they never make any sort of sign in order to communicate anything to one another, to call them, or give an alarm, or express some peculiar sensation ?*

Experience would entirely deny any such assertion. And this not only with reference to the superior animals, for this faculty appears to be extended even to the invertebrata. Thewell-known experiments of $\mathrm{P}$. Huber seem to have proved in the most decisive manner that ants, $\uparrow$ like bees, are able to transmit certain signs or indications from one to the other; even if the mere act of living in a republic, of joining together in one common work, did not offer the strongest presumption of a language peculiar to these creatures. If anyone dares to deny to animals the spontaneous exercise of a restricted language, limited in whatever way that may be desired, at least it cannot be denied that many of the vertebrate animals are not capable of receiving from it an equal education, of understanding the signification of certain sounds, of certain signs, and of producing in their turn such as may be understood by us, of communicating to us any of their thoughts, or any of their appreciations.

We are not speaking here of animals who can reproduce certain sounds belonging to the vocal organs of man; that is a fact of an entirely material character, and which has no reference to the question of language. It is evident that the animal which articulates any word whatsoever does not understand it a whit more than the man who imitates the cry of an animal, and, in a general way, neither comprehends its sense nor its signification.

* Recherches sur les mœurs de fourmis indigènes, Genève, 1810.

+ We refer our readers for all these questions to the remarkable works of M. Toussenel. 
Maupertuis alleges* that if animals were capable of understanding we could teach them to make themselves understood by other signs in default of a voice. A strange aberration of intellect for such a studious and learned man. This is the man who makes an impossibility out of an everyday occurrence; for, first of all, most animals have some sort of voice, and if they had it not, there are few persons who are ignorant of the way in which certain mute dogs make themselves understood when they particularly desire it. What would really be absurd would be the hope of imparting ideas to animals, matters relating, indeed, to a higher order, since we see that even all men are not capable of grasping them. Man has been able to train animals, and to train implies precisely the idea of communicating a thought from man to an animal, and from the animal to man. "Jump," says the shepherd to his dog, and the dog knows that this vocal articulation orders him to make a given muscular effort. The man has spoken to the dog. During the night some one opens the gate of the farm-jard, and the watch-dog barks; he thus tells his master that something unusual is happening. $\dagger$

That which proves besides that the barking of the dog is merely a conventional sign, an artificial language, so to say, is the fact, that in certain countries the dogs do not bark; jackals and wolves learn how to bark when in company with the dogs who can talk in this manner, and that the same dogs lose the power, or rather the habit of barking, if they return to a savage state. $f$

We have already spoken of those inferior races which seem to have borrowed from their better endowed neighbours a rudiment of civilisation, which, for a long time they did not know

* Essai Philosophique sur l'âme des Bêtes, 1728, p. 217.

+ It may be seen, in analysing these two simple facts, that they lead us to admit the existence of a notion of duty among animals, although, perhaps, an obscure one:- they know that they ought to act as they are doing from fear of a whipping, and this is an operation of the mind which no one, we think, will deny to be complex in its nature, and purely intellectual.

‡ Isid. Geoffroy Saint-Hilaire, Histoire Naturelle Générale, vol. iii, 1860, p. 114. M. Roulin has remarked, that there is something analogous in this as regards the cat, which loses, in the savage state, those troublesome mewings which we hear so often during the night from the European race.-Mémoires du Muséum d'Histoire Naturelle, vol. xvii. 
how to develope in any way. Does it not seem that there is here some comparison with what has just been stated? that under a civilising influence, in contact with a superior being, the dog has learnt a language ; but that not understanding its general application (a more complex, and more highly elevated idea), he has not known how to transmit the use of it to his own race, or has himself forgotten it, from not having any occasion to exercise this power?*

The language of animals is still a question full of obscurity, but which may eventually, we believe, become fruitful in new facts. $†$

If Apollonius of Tyana and the ancient philosophers did not understand the language of animals so well as has sometimes been believed, at least they did not do wrong in directing their inquiries towards this matter. We have no doubt but that in carefully studying animals, we shall arrive at a scientific explanation of this well-known truth, recognised by all those who live with them; which is that they can understand us, that they make themselves understood by us, and that they understood one another within certain limits. $f$

For a long time it was believed that intellect and thought belong to man alone, and that he had only organic instinct in common with animals. $\S$ This opinion tends each day towards

* It is because there is a sort of capability for education in the animal, and indeed in the whole of his race, placed under certain circumstances; it is because, on the other hand, we refuse to certain human races the "initiative in progress," (see Broca, Bulletins de la Société d'Anthropologie, May 24 and June 21, 1860), that we cannot accept the "class man" of M. Chevreul, preceding the "class mammalia," and having, as a characteristic, the capability of perfection in the individual, and in the association of individuals. - See Exposé d'un moyen de Définir et de Nommer les Couleurs, § 185. (Mémoires de l'Académie des Sciences, vol. xxxiii, 1861.)

+ See Dr. Gibson, Amer. Assoc. (compare Ami des Sciences, 29 August, 1858.)

I It would be a curious study, for instance, to find out if certain noises, - certain sounds which have no signification to our ears, do not produce, among some animals, clearly determined impressions, having their first origin in these animals themselves, or in their mutual relations, the education we give them going for nothing in this sort of evidence.

$\S$ [The Rev. F. W. Robertson (who died some years ago), states some opinions in his published sermons which show he was almost before his time in his ideas concerning animals. He says, in comparing them with mankind, "There is the same external form, the same material in the bloodvessels, in the nerves, and in the muscular system. Nay, more than that, our appetites and instincts are alike, our lower pleasures like their lower pleasures, our lower pain like their lower pain; our life is supported by the 
a change; we hope that we have proved so much. Something of the same sort will take place, we think, for the best studied language. There, as with intellect, as with organism, we shall doubtless be able to prove a unity which may be regarded by analogy as necessary, offering alone degrees of gradation in reference to organism and intellect. Every living being (we are only speaking here of vertebrate animals) will appear to be composed of the same constituent parts, but unequally developed, and of which some have only been taken by us for dissimilarities or new parts, on account of our own want of sufficiently deep study. As they formerly tried to discover new bones in the heads of fishes, until the time when their relations, connexions, and development were better studied; so unity of composition has been there recognised and proved where it was least suspected.

We cannot do better, in order to sum up our ideas on this subject, than quote a passage from the works of a learned man, who in our days has gone most deeply into the study of organic homology, Professor Richard Owen; it is the last step which has been taken, and indeed the most decisive one, in the momentous question concerning man's place in nature.

"Not being able to appreciate or conceive of the distinction between the psychical phenomena of a chimpanzee and of a Bosjesman, or of an Aztec with arrested brain-growth, as being of a nature so essential as to preclude a comparison between them, or as being other than a difference of degree, I cannot shut my eyes to the significance of that all-pervading similitude of structure-every tooth, every bone, strictly homologous -which makes the determination of the difference between Homo and Pithecus the anatomist's difficulty. And therefore,

same means, and our animal functions are almost indistinguishably the same." Sermons, 3rd series, 1857 (preached in 1850), p. 49. "It is the law of being, that in proportion as you rise from lower to higher life, the parts are more distinctly dereloped, while yet the unity becomes more entire. You find, for example, in the lowest forms of animal life, one organ performs several functions; one organ being, at the same time, heart, and brain, and blood-vessel. But when you come to man, you find all these various functions existing in different organs, and every organ more distinctly developed; and yet the unity of a man is a higher unity than that of a limpet." (Sermons, p. 57.)-EDITOR.] 
with every respect for the author of the Records of Creation,* I follow Linnæus $\dagger$ and Cuvier in regarding mankind as a legitimate subject of zoological comparison and classification. †" Is not the admission of gradation the means of binding more firmly together the great chain of human beings, a thing quite impossible, which could not exist, or rather, which would only be a caprice,-an artificial method or system,-if the classified beingss were only thus classified by creatures of their own description? Does it not confirm, even more strongly, the continuous series in which Aristotle, Leibnitz, Bonnet, Linnæus, and de Blainville have believed? We shall proclaim, then, the law, shaped by M. Flourens, who, however, does not receive it, as we do, without reservation:-

LAw.-From animals to man everything is but a chain of uninterrupted gradation; therefore, there is no human kingdom. Then comes this other conclusion,- - one and the same method is applicable both to mankind and animals.

* A Treatise on the Records of the Creation, by J. Bird Sumner, Lord Archbishop of Canterbury, 6th edit., 8vo, London, 1850.

+ Nullum characterem hactenus eruere potui, unde homo a simia internoscatur.-Linnæus, Fauna Suecica: præfatio.

¥ Owen, On the Characters of the Class Mammalia, p. 20, note (Journal of Proceedings of Linnean Society, 1857.) 


\section{CHAPTER III.}

\section{THE ORDER OF BIMANA.}

THE naturalist who has in our time most interested himself in the classification of vertebrata, Prince Charles Bonaparte, gives his own opinion as follows :- "Man may be considered, in one point of view, as constituting one single family; in another, as constituting an entire kingdom." But he also adds that in this second case, "the characteristics are no longer in harmony with the rest of the system." In fact, we can hardly at the same time admit both the general principles of classification, as followed at the present day, and also the human kingdom. One out of these two things must fall to the ground. The system of classifying mammalia,-adopted in all its uniformity by the two Geoffroys, the Cuviers, De Blainville, and Owen,-cannot be maintained without involving mankind. If man were a kingdom by himself, this classification would be a false one; for ought we not then, at least, to create a cetaceous kingdom, a bird kingdom, etc.? As for ourselves, the problem has been already solved, and we hesitated to come into collision with this new inconsistency. Harmony is the necessary condition of every really natural system. We cannot arbitrarily give a different value to the same characteristics; and, reciprocally, the divisions of the same order ought necessarily to agree with characteristics of the same value.

It has been thought necessary, at least, to create for mankind one of those great divisions into which the mammalia are divided. An Order of Bimana has been created. We do not hesitate to say that this was a purely theoretical creation; and we will go even farther, we declare it could only be produced 
in a country where covering's for the feet are in daily and universal wear. We must not go into the midst of our great cities if we wish to study the zoological characteristics of man.

Is there any reason for the Order of Bimana when we consider man in his state of nature? is it "the immediate and necessary results of natural analogies, respectively valued according to their degree?" "No !" was the answer of Etienne Geoffroy, in his eloquent pages, " this Order must be abolished."*

E. Geoffroy saw workmen in the bazaars at Cairo employ their great toe for numberless prehensile uses. A Nubian, or a negro on horseback, generally takes the stirrup-leather between his great toe and the others; all the Abyssinian cavalry ride in this manner. $\dagger$ If the fact reported by Bory de Saint-Vincent about the rosin-makers of the Landes is not confirmed, $\ddagger$ we have at least seen the Barabras Nubians ascend the great yard of the Nile dahabiehs by seizing with the great toe the rope underneath them $\S$ which supports the sail.

When the action of the foot is not paralysed by the size of the shoe, which is elsewhere the exception, it is pre-eminently adapted for laying hold of anything. And if certain kinds of men seem to us very fit for the kind of existence led by the Quadrumana,-if they seem to us constituted in order to live in trees, there is nothing there which ought to surprise us, nothing but what is quite natural and quite consistent.

It has been truly said, that man is frugivorous. All the details of his intestinal canal, and above all, his dentition, prove it in the most decided manner. He ought, therefore, from his origin, to have all his organism modified in harmony with this alimentation. Like the apes, he ought to possess such means of locomotion as would enable him to procure the food specially adapted to his wants. And therefore, what is there astonishing in the fact that among certain races, which are scarcely

* Comptes Rendus de l'Académie des Sciences, vol. ii, p. 581.

+ See the magnificent work, Sketches of Central Africa, and the portrait of the chief, Kanéma, in Barth's Travels, vol. iii.

† Isidore Geoffroy Saint-Hilaire, Hist. Naturelle Générale, rol. ii, pp. 200-515.

$\S$ [See Huxley's Man's Place in Nature, 8vo, London, 1863; and the article thereon in the Edinburgh Review, April, 1863.-EDIToR.] 
removed from a state of nature, we find the remains of a mode of life which was general at their origin.

Modera, quoted by Mr. Crawfurd, relates that one day, three naturalists, travelling on the northern coast of New Guinea for scientific purposes, found the trees full of natives, of both sexes, who leaped from branch to branch like monkeys, with their weapons fastened on their backs, gesticulating, shouting, and laughing.* This singular race, of which we have before spoken, and which has been noticed in Hindoostan by many eye-witnesses, seems to live half its time in trees. We have the right to ask, if the confused remembrance of such a race and such habits was not the origin of the tradition which served as a foundation for the poem of Valmîki. Rama goes to the rescue of his wife, Sita, who had been carried off by the evil genius, Râvana; he is assisted in this enterprise by a valiant army of monkeys, and at every moment expressions are used in the account which recall the monkey-like and quadrumanous nature of the combatantst. In casting our eyes over the first groups composing the mammalian series, we find some apes who walk upon the sole of the feet and upon the palm of the hand; others, who walk upon the sole of the foot and the joints of the folded hands, - a very peculiar method of progression,-of a strange and unexpected nature, and which alone would serve to characterise a group; these are the anthropomorphous apes: lastly, another mammal who walks only on the soles of the feet, the form of the body and legs rendering the anterior members quite unfit to be used in walking; this is man.

The first apes of which we are going to speak, walking upon the sole of the feet and the palms of their hands are, then, unreservedly quadrupeds. In this particularity they resemble other mammalia, among whom the pectoral, as well as the abdominal, members are chiefly organs of locomotion; only these apes also use their four extremities for another purpose,

* Crawfurd, On the Negro Race, etc. (British Association for the Advancement of Science, 1852, p. 86.)

+ See the translation of this veritable Iliad, by M. H. Fauche. Râmayana, 1857. 
which appears to be entirely secondary and derived,-that of prehension. And it is precisely because the organisation of their members is purposely modified by reason of a new, special, and uncommon function, that they have been able to furnish us with a sufficiently defined characteristic, so that we may specify an order,- that of the quadrumana.

Among the anthropomorphous apes, the folded or bent hand seems an organ especially adapted for prehension,* serving, in a secondary manner, for locomotion; whilst the foot, the especial organ of locomotion, preserves the faculty of seizing anything by means of an opposing thumb.

In man, the superior member is not at all fit for walking; and the inferior, used for locomotion, as in the two preceding groups, also preserves its faculty of prehension: observation proves this as well as anatomy.

We see that there again, as everywhere else in an organic point of view, the anthropomorphous quadrumana are a veritable transition from man to the other families of apes. It has been proposed to extend the signification of the word hand, and to apply it to every terminal extremity of a member capable of seizing anything, including the paw of the lemur and the claws of the parrot. We are inclined to restrict the name, like Linnæus, De Blainville, and Cuvier, to an extremity formed of fingers, and with an opposing thumb. But even in confining the definition to such a narrow compass, we think we have shown that man, in reality, is quadrumanous, this definition applying equally to the foot, where the great toe serves -among half the people, at least, on the earth-for the purpose of prehension, and remains, as E. Geoffroy has remarked,

* [We are told in the Voyages de François Pyrard, vol. ii, p. 331, Paris, 1615, " that in the province of Sierra Leone there is a species (of orang-outang) so strong limbed and so industrious that, when properly trained and fed, they work like servants; that they generally walk on the two hind feet; that they pound any substances in a mortar; that they go and bring water from the river in small pitchers, which they carry, full, on their heads. But when they arrive at the door, if the pitchers are not soon taken off, they allow them to fall; and when they perceive the pitchers overturned and broken they weep and lament." In the Voyages de Guat. Shoutten aux Indes Orientales, we find nearly the same account of the orang: "they are taken with snares, taught to walk on their hind feet, and to use their fore-feet as hands in performing different operations, as rinsing glasses, carrying drink round to the company, turning a spit," etc.-EDrTor.] 
quite separate from the other toes, when the foot is not deformed by boots or shoes :* therefore, nothing more can be said in favour of an Order of Bimana, or a human kingdom.

We must return to the subdivision proposed by Charles Bonaparte,-a family. Man constitutes a simple family in the Order of Quadrumana, distinguished by characteristics precisely equal in importance to those which make a difference between other similar groups in the class of mammalia, that which even comes to the assistance of the adversaries of the human kingdom, and the partisans of the zoological system. For want of positive characteristics taken from the extremities, which could never, -in the eyes of true naturalists, as we have just said,-favour a serious distinction between man and other quadrumana, a characteristic in dentition has been discovered, remarkable for its constancy even in the most degraded and animal-like races, and which, first and foremost, distinguishes man from the group which immediately follows him in the zoological series. This characteristic, upon which Professor Owen has, in many places, insisted,-like the two Cuviers, but with an entirely new vigour, $\dagger$ is the contiguity of the teeth and the continuity of their crowns, not one of which ever extends beyond the level of the others. $f$

Thus it is for man, like the rest of the mammalia; it is the dental system which gives us the best characteristic. A new proof that the study of mankind and that of animals ought to be conducted in one and the same manner; a proof, indeed, that these two studies are two parallel branches, intimately united, of one and the same science.

* Comptes Rendus de l'Académie des Sciences, vol. ii. See, also, for the separation of the great toe, the photographs in the Voyage da la Côte Orientale d'Afrique, by Captain Guillain.

+ Odontography, London, 1840, p. 452. Catalogue of the Hunterian Collection, "Osteology," vol. ii, p. 800.

I [A character which, as the Cuviers and Owen have pointed out, man shares with the fossil Anoplotherium and its allies, from the Paris gypsum.EDITOR.] 


\section{CHAPTER IV.}

\section{ANATOMICAL, PHYSIOLOGICAL, AND PATHOLOGICAL VARIETIES.}

WE have endeavoured to prove in the preceding pages the specific unity of the biological phenomena in each Order, which are to be found among the superior animals and man. This unity has led us necessarily to another, that of method; and we have just seen that man forms simply a family, that is to say, a very secondary division in the zoological series.

But we have only taken the first step of the path in which we have to travel. The genus homo shows many varieties, and many dissimilarities. We must try to estimate their value, and to find out what the divisions to be established between what we commonly call races of men may be worth. Now, the only rule to be followed here is naturally that which is applied by all zoologists to the other individuals composing the animal series. The only way to arrive at such a goal will be, first of all, the study of the physical differences, the necessary basis of a rational classification. Thus we shall, at least, have important, and what is more, comparable results.

The anatomy of races has been largely written about, and yet we may even now offer this subject to the serious study of anthropologists; perhaps, also, in carrying their attention farther than the skin, the encephalic mass and the skeleton, which have been nearly the sole objects of study up to the present time, they will find in all systems dissimilarities of the same order, and as clearly defined.* These differences and

* Tiedemann, of Heidelberg, wrote to Knox with reference to the nervous system, that he had great reason to believe that the natives of Australia 
varieties are such that they are obvious, and at once appreciated even by ignorant persons, *-they are such that the most eminent monogenists agree in regarding them as everywhere sufficient to make a difference in species, or even in genus itself.

They refer to every point of organisation, and we shall see farther on that they are found to be as decided and as palpable both in the mind and in the natural constitution. We do not pretend to speak of all of them in this place, not even to enumerate them; we shall merely quote the principal points, or those which appear to deserve some special remark. The number of those which exist, or which are believed to exist,for this is a necessary restriction,-is immense; in fact, if we are the first to admit that there is an infinite variety of differences, considerable in themselves, between the various kinds of men, we also wish to avoid falling into the errors which are so often committed, and which happen from the small number of facts which have been observed, the investigators having often given the value of general facts to individual observation.

We find more than one example of these hasty opinions in the history of anthropological studies. Towards the end of the last century, when the colour of the Negro had already been for a hundred years the dominant study of the scientific world of Europe, $†$ a certain Kluegel affirmed (in the Encyclopédie de Berlin, 1782) that the lips of the Ethiopian were of a fine red colour. A great commotion arose ; Sömmering himself was roused; he wrote everywhere, sought for information,

differed in this matter from Europeans in an extraordinary degree.-Knox, The Races of Men, London, 1850, p. 2.

* "The physical characteristics which distinguish human races, one from the other, are, perhaps, the one fact in natural history which has always most struck the imagination of mankind. . . Historians relate, that when Columbus first returned, Europeans could not take their eyes off the plants and unknown animals which he had brought with him ; and above all, the Indians, so different from all the races of men they had ever seen."'-Flourens, considérations sur l'enseignement de l'Histoire Naturelle de l'Homme. (Annales des Sciences Naturelles, vol. $\mathrm{x}, \mathrm{p} .357$.$) This wonder is renewed every day; and$ I once knew an intelligent negro who had a very unpleasant remembrance of the French provinces, where he had been the object of a very general and indiscreet curiosity.

+ 'The works which followed one another on this subject are due to Reinhold Wagner (1699), B. S. Albin (1737), Barrière (1742), Mitchell (1744), Baeck (1748), Meckel (1753-1757), Le Cat (1756-1765), etc. See G. Pouchet, Des Colorations de l'Epiderme, 4to, Paris, 1864. 
and demanded fresh intelligence, which, quite naturally, was found to be contrary to the opinion expressed by Kluegel. In fact, we know that in the Negro the colouring matter extends to most of the mucous membranes whose structure resembles that of the skin.

The lips are generally black, and we usually find upon the gums, and even upon the palate, a non-continuous coloured membrane, which forms spots of a deep violet colour. Kluegel had concluded too hastily from some particular fact; he had in his mind, very probably, some Negro with lips, gums, and tongue of a fine rose colour, contrasting as much as possible with the black of his skin. We have had occasion ourselves to observe a similar case as regards a native of Soudan, who was also affected with a sort of partial albinoism of the buccal mucous membrane.

In anthropology, as in all science requiring observation, it is the averages which ought to be admitted as evidence; they alone have an absolute value, and can alone lead to positive results. Every isolated phenomenon has its individual value as regards its simple truth, but we are exposed to the greatest errors when we begin to generalise from it.

The osseous system has been most studied.* In the osseous system, the head, and particularly the skull. We shall be obliged, later on, to refer to the value of cranioscopic proceedings, and the classifications resting on this base.

The face, as well as the skull, has been the object of attentive inquiry; the smallest differences have been noticed, and almost all have been formed by some one or other into distinct characteristics. We may quote here Bérard's classification, as resumed and developed by Isidore Geoffroy Saint-Hilaire. $\mathrm{He}$ divided the genus homo into four groups:-

1. The orthognathi, or men with a flat face and oval countenance.

2. The eurygnathi, or men with a large face and projecting cheek bones.

\footnotetext{
* The analysis of the anatomical differences in the skeleton has been, perhaps, best made by Bérard, in France, and Lawrence in England; I may refer for the details to these two authors. Bérard, Cours de Physiologie, 1848, vol. i; Lawrence, Lectures on Comparative Anatomy, 9th edition, 1848.
} 
3. The prognathi, or men with a protuberant countenance.

4. Lastly, these races, which are both eurygnathi and prognathi, like the Hottentots, the development of whose face offers an example of a manifest step towards the exaggeration of this same development in the anthropomorphous ape in infancy.*

It has been endeavoured to establish, by means of averages, an appreciable difference between the pelvis of various races. Weber has considered that the form of the superior division is not the same with all of them. According to him it would be-

1. Oval, among Europeans.

2. Round, among Americans.

3. Square, among the Mongols.

4. Cuneiform or oblong, among the Africans.

The same ideas have been resumed and defended by French anthropologists ; $\dagger$ it is right, however, to remark, that Weber himself adds that varieties of every description of pelvis may be met with among the same race. That which appears certain is the fact, that in the Negro race the pelvis is, in general, sensibly smaller. This is, at least, the opinion of Camper, Vrolik, Sömmering, White, $\S$ and Bérard, || who have measured a great number of them.

The facility in parturition, so remarkable among the inferior races, has therefore, as a cause, a relative smallness in the head of the fœtus, even more remarkable. For we must admit that, among these people, everything happens naturally, as among animals; it is the laborious childbirth among ourselves which is exceptional and anomalous, and which requires to be explained. This difficult and painful parturition, which we so continually see, is, doubtless, the consequence of civilisation;

* Is. Geoffroy de Saint-Hilaire, "Sur la Classification Anthropologique," Mém. de la Société d'Anthropologie, 1861, vol. i, p. 125.

+ [Compare Joulin, Anatomie et Physiologie comparé du bassin des Mammifères, 8vo, Paris, 1864; and Mémoire sur le bassin considéré dans les Races Humaines, 8vo, Paris, 1864.-Editor.] little,

₹ The proportion given by Camper is this: the great diameter is to the

In the European : : $41: 27$.

In the Negro : : $39: 27 \cdot 5$.

§ Account of the Regular Gradation of Man, 4to, London, 1799, p. 118.

II Cours de Physiologie, Paris, 1848, vol. i, p. 394. See, also, on the same question, A. Maury, in the Athénéum Français, 1853, No. 47. 
only it is difficult to decide what may be its immediate cause, and if this cause resides in the mother or in the fœtus. Is it the pelvis which has been made narrower in the European by some custom in our manners-by some habit of education? or must we admit-and it is a serious question-that the development of such an organ as the brain in the fatus, is subordinate to the exercise of the functions of the same organ in the progenitors?

With the osseous system we may connect the differences of height which are so apparent. Who does not recognise that in Europe, for instance, the Anglo-Saxons, the Germans, the Norwegians, and the Albanians, are of great stature; whilst the inhabitants of the south of France, the Irish, the Spaniards,* and the Maltese, represent a shorter variety of the human race. The members show the most marked differences among the various races of mankind, by reason of the law which causes the modifications of organism to become more and more decided, and more and more clear from the centre to the periphery. Naturalists seek for characteristics of families and individuals in the fingers and in the teeth: it is in the extremes of an individual, in the colour of the hair or the skin, that we generally find the characteristics of species. We shall only quote in this place facts which may be the object of some particular remark.

It has been said continually that the Tartars have bowed legs, and monogenists have not failed to discover from this fact a new proof of the influences of their mode of life, so necessary in order to maintain their thesis. They discovered at first sight, in this general infirmity, a consequence of the habit of riding on horseback, without considering that the Arabs rode on horseback quite as often, and that, nevertheless, their noble bearing and straightness of limb did not suffer from it in the slightest. In tracing the source of this error, we perceive that it is a singular exaggeration of the facts stated

* [We cannot entirely agree with the author regarding the low stature of the Spaniards. From our own observation we may unreservedly say that, at all events, the inhabitants of the south and south western parts of Spain are a fine race, not at all liable to the charge of being different in height from the Anglo-Saxons.-EDrTor.] 
by Pallas, who lived for so long a time amongst the Tartars. He simply says, "The sole fault in conformation which is rather frequent among them, is a bend in the arms and legs, resulting from a kind of spoon, or saddle, upon which they are always placed in their cradle, as if they were on horseback, and therefore, as soon as they learn to walk, they are obliged at every movement to accustom themselves to the position of riding."* This is what Pallas says; but it is very clear that he is here speaking merely of exceptional cases, for he says higher up, "I do not remember to have ever seen a child who was a cripple. Their education, which is entirely left to nature, can only form bodies which are healthy and without a blemish." $\dagger$ If occasionally the accounts of travellers have been exaggerated, it is not less the rule, that certain races show a conformation of the extremities very different to what it is among ourselves. Albrecht Durer has already made this remark. In the Negro, for instance, the length of the forearm is much greater than in the European. It is proportional to the height in these two races : : $107: 100$.

The thumb of the Negro's hand is also generally much less opposed to the other fingers. In certain races of mankind, the hand itself is of an extraordinary small size. This is the case among the Bosjesmans, the Chinese, the Esquimaux, $\S$ and the Cingalese.\| It was the same among the races who built the grand American temples, where we find upon the stones the imprint in red of their hands. T The same thing has been said about the ancient population of northern Europe, who were ignorant of the use of iron, and only used weapons made of bronze.** But the study of the magnificent collection of

* [Although our author rather despises the idea of the legs being bowed by riding, it is tolerably well known in this country that too much riding on horseback, when young, and especially on large animals, is very apt to alter the shape of delicate and weakly limbs.-EDITor.]

† "Tribus Mongoles," translated by S. A. de Grandsagne, in the Mémoires du Muséum, vol. xvii.

† See Broca, Bulletins de la Société d'Anthropologie, 3rd April, 1862.

$\S$ See Lawrence, Lectures on Comparative Anatomy, London, 1848, p. 410.

II Davy, An Account of the Interior of Ceylon, 1821, p. 109.

T See Daniel Wilson, in the British Review, 1851; and in Stephens, the description of the Temple of Uxmal.

** See Bulletins de la Sociëté de Géographie, 4th series, vol. x, p. 45. It 
Scandinavian antiquities in the Berlin Museum, has not proved to ourselves that the hilts of all these arms were as small as has been pretended.

The foot varies not less. The Negro races of the Oceanic Islands, and of Africa, appear to show an exaggerated development of the heel-bone. MM. Quoy and Gaimard have especially remarked it among the inhabitants of Vanikoro. In fact, there is hardly anybody who will forget, when once he has seen it, the special aspect of the instep in the Negro, ridged with numerous folds commencing from beneath the ankle. This is, besides, a particular mark, which is far from showing itself, as may be well believed, among all people who walk without foot-covering. The foot of the Nubians, and especially that of the females, shows quite different characteristics. The five metatarsi seem to rest their whole length upon the ground, without being shaped by the instep; their anterior extremities are slightly diverted, the toes having the same spaces between them, so that the foot is flat, but otherwise than by the faulty conformation to which we give this name among ourselves. This structure is, besides, perfectly represented in all Egyptian statues without exception, and more sensibly, indeed, if we compare with those which are in the galleries of the British Museum, a fragment of a colossal foot,* found also in Egypt, at Alexandria, but evidently of Greek or Roman origin; the toes are close together, the great toe alone being separated, the upper part of the foot being arched, as among Europeans.

This resemblance between all the Egyptian statues and the foot of the inhabitants of Upper Egypt, or Nubia, cannot be an accidental circumstance. It is, besides, a veritable problem in anthropology, to determine its value in accordance with the monumental iconography of the ancient Egyptians. M. A. Maury has determined with precision the authority of the portraits-almost all alike-which cover the walls of the

must not be forgotten that these weapons with a small handle may have been used by those valiant heroines, whose praises have so often been sung in the songs of the north.

* Presented by A. C. Harris, Esq., 1840. 
temples. We ourselves, when visiting the famous cavern of Abou-Simbel, were far from finding all that the writings of certain anthropologists and partisans of Egyptian art, such as Gliddon, Nott, etc., had promised us. Doubtless, one can perfectly distinguish certain types,* that is indisputable; $\dagger$ but to desire to find a people in each portrait,-Scythians, Arabs, Philistines, Lydians, Kurds, Hindoos, Jews, Chinese, Tyrians, Pelasgians, Ionians, etc.,-is it not to give too great an influence to the Egyptian artists, who were copyists without skill, and but clumsy inventors? Egyptian art, whatever may have been said of it, has always been very much farther from being a copy of nature than Grecian art; the one tended to the ideal, the other tended to transform it. Certain trees which we see thrown down in the bas-relief of the great temple of Karnak, are assuredly pure imagination. It may have been the same with many other subjects to which a scientific value has been given.

Let us return to anatomical differences, and to that which has, since antiquity, most vividly struck the masses, as well as serious investigators. We are going to speak about those colours in the skin of man which run through almost the whole of the chromatic scale, from dead white to the deepest brown. $\ddagger$ There is no system which has not been thought of in order to explain these differences, even up to the influence of Noah's curse. $\S$

Unfortunately, we are wanting in those histological and chemical researches which are necessary in order to form the bases of a complete history of the colours of the skin in the human race.\| We can merely say, that the recent works upon certain morbid states, such as Addison's disease, and others

* Compare the memoir of Professor C. G. Carus, Ueber die Typisch geurdenen abbildungen menschlichen kopfformen namentlich auf münzen in verschiedenen zeiten und volkern, published in the Novorum Actorum Academia Casarea Leopoldini-Carolince Germanica naturæ curiosum for 1863, in which the author gives characteristic examples of the ancient types, as deduced from the examination of coins, etc. Compare, also, Nott and Gliddon, Types of Mankind. -EDITOR.]

+ See especially Lepsius, Denkmaeler von Egypten und Ethiopen, vol. ii, pl. 133 ; vol. iii, pl. 116, 117, 118, 136.

† Bérard, Cours de Physiologie, Paris, 1848, vol. i, p. 394.

$\S$ See J. H. Hanneman, Curiosum Scrutinium Nigredinus Posterorum Cham, in 4to, Kiloni, 1677, § 14 .

|| See Pruner-Bey, Bulletins de la Société d'Anthropologie, 5th March, 1863. 
which may approach it, by making us acquainted with the pathological circumstances under which the European with a white skin becomes almost as black as a Negro, and by identical anatomical modifications, have nearly proved that atmospheric phenomena have not the influence which monogenists give to them, and that the first origin of the colour of the epidermis in the human race resides rather in the depths of the organism, inaccessible to celestial radiation.*

The varieties which the pilous system presents is the chief point, and equal at least in importance to those of the cutaneous system. If we think that a classification of races, based simply upon the characteristics of the hair, as has been proposed, $\uparrow$ would leave much to be desired, and would be far too artificial, we do not doubt, however, but that the pilous system can furnish indications of great value when they have been combined in a wise manner with other characteristics, as Isidore Geoffroy Saint-Hilaire has done. $\neq$ Doubtless, the colours of the hair, from flaxen to black, and from brown to red, are innumerable in France, and as generally so in countries where the mixture of races has been carried as far as possible; but it must be remembered that among a purer population, less mixed with foreign blood, the constancy of characteristics taken from the hair is remarkably great. $\$$ Besides, the differences which present themselves do not relate merely to colour; the hair of a race of men may be either smooth, or woolly, or crisped, for in general these two latter terms are wrongly and indifferently used, when they ought really to point out two particular and distinct states. It is thus that the inhabitants of Lower Nubia, for instance, who have a very deep shade of colour, possess curled hair, truly woolly, and quite different to that of the Negro, whose hair is really crisped.\| Other cha-

* See, upon this point, G. Pouchet, Des Colorations de l'Epiderme, 4to, Paris, 1864.

† Bory de Saint-Vincent divided mankind into Leucotriques and Ulotriques (see Bérard, Cours de Physiologie, 1848, vol. i, p. 394). Prichard refers all these races to the three following types:-1. Melanocomous; 2. Leucous; 3. Xanthous (see English Cyclopcedia, art. "Man").

+ Tableau Synoptique des Rnces Humaines (Mém. de la Société d'Anthropologie, vol. i, p. 143).

§ See Pruner-Bey, De la Chevelure (Mem. de la Soc. d'Anthrop., vol. ii, p. 1).

II See Smith, The Natural History of the Human Species, p. 189. 
racteristics may be demanded from the length of the hair, from its transverse section,- the figure of which may vary considerably,-from its flexibility or its quantity; in fact, even from its manner of being placed in the head, the arrangement of which upon the scalp has never been properly studied, and which may, perhaps, vary with the different races of mankind. In fact, human hairs, like that of many mammalia, are not placed at equal distances the one from the other; they approach each other in little groups. This is especially seen in the nape of the neck, and among the Negro race much more so than among the Europeans.

This fact, joined to the irregularly prismatic form of the hair in the Negro, is doubtless the origin of the following peculiarity : when the head of a Negro has been shaved, and the hair begins to grow afresh, one is especially struck with its strange appearance. It is arranged in little tufts about the size of a pea, so that the head, it has been remarked,* resembles nothing more closely than an old worn-out brush.

This peculiarity is special to the Negro, and is not found in the north-east of Africa, where the neighbouring population have woolly hair. Among the enumeration of the numberless perfections which a dogmatic Hindú requires from Buddha, and which Çakhya-Mouni possessed, it is said, "The hair of Buddha shoots forth in little ringlets." $\dagger$ It is impossible to describe better what happens with the Negro. All this Hindoo tradition is, besides, a veritable enigma for the anthropologist. Why is Buddha depicted with the palms of the hands descending to the knees? Why is the mendicant son of a king, born on the banks of the Ganges, always represented with the features or characteristics of a Negro, with black skin, and crisped hair? Nevertheless, Çakhya-Mouni did not belong to these inferior varieties of the human race, of whose existence in the Indian Peninsula we have already spoken; in that case, he would have been unfit to formulate any doctrine, either moral or philosophic.

\footnotetext{
* See Earl, quoted by Crawfurd, On the Negro Race, etc. (British Association, 1852, p. 86.)

+ Compare Bornouf, Le Lotus de la bonne loi, p. 562.

‡ Compare, idem, ibidem, p. 569.
} 
The rest of the pilous system, not less than that of the hair, merits the attention of the anthropologist. Thus, a very especial fact, and to which, in our opinion, sufficient importance has never been attached, is, on the one hand, the relative abundance of the beard among the various races of mankind; and on the other, the time of its development. The Chinese, for example, is for a long time beardless, and it is only about his fortieth - year that a few stiff hairs begin to appear upon his face.

Among the Negroes, the Americans, and the Polar race, the hair is, in the same way, very slightly developed on the face. "The length of our beards (of thirty days growth), which had not been shaved since we left the Victory," said Sir John Ross,* "was, among other things, a source of great amusement, while one of them, a stranger, whose beard was of unusual length among this tribe, claimed consanguinity with us on that ground." The thick and close beard seems, in regarding the matter closely, the exclusive appanage of that race which, sprung from the Imaüs, spread over the whole of Europe, and whose finest representatives still inhabit the table-lands of Iran. $\dagger$ Our neighbours, the Semites, are far from being so well provided; and Lieut.-Colonel H. Smith has $\ddagger$ not, perhaps, done wrong in proposing to make an abundant pilous system the characteristic of one race, just as the crisped state of the hair would become the characteristic of another.

The systems of animal life, doubtless, show as many varieties among different races of men as the systems of the life of relationship; only these varieties are much less known. It will be sufficient for us to remember in this place the darker colour of the blood and the sperma among the Negro race, as already remarked by Aristotle and verified by Jacquinot, and the equally dark tint of the nervous centres; so that the whole œconomy of the Negro is, even in the most hidden parts (and those most distant from solar or atmospheric influence), impregnated with colouring matter.

Let us notice, also, the development of the small labia

* Narrative of a Second Voyage, etc., 1835, p. 427.

+ [The name given to Persia by its inhabitants.-EDitor.]

\$ Compare The Natural History of the Human Species. 
among the Hottentot women, that of the prepuce and the clitoris among the Semitic race, and even the size of the penis among the Ethiopians - such a size that it would almost impede the union of a black man with a white woman, whilst the union of a white man with a Negress would occur without any impediment. This remark, quite in agreement with the theories of M. d'Eichthal, has been made by a monogenist;* we have merely the right to wonder at it. How can we reconcile this impossibility, were it even a shade of a real one, with the notion of indefinite and universal reproduction, which all monogenists-wrongly, as we shall see-make one of their strongest arguments in favour of the specific unity of man?

II. What we call physiological differences are certain functional forms of the same organ, particular to certain races. This is, as may be seen, an entirely artificial distinction, since these differences must necessarily and forcibly refer to material, that is, to anatomical differences.

These alone, either from their small value, or from some other cause, have been hitherto unknown; whilst their effects, being more sensible, have not failed to escape our observation. If an Esquimaux, for instance, eats in one day the food of six English sailors, + it is evident that the intestines, the stomach, and the glands which border on them, present special modifications with reference to this kind of nourishment, so different from the frugivorous diet for which man's organism is adapted. When a Tartar sees further than a European who is using a telescope, $\ddagger$ it is certain that such a functional superiority depends only on the material quality of the organ,-from a more perfect arrangement of the visual apparatus,-from the more perfect nature of the medium refractive powers of the eye.

It has often been desired to refer these kind of modifications to the education of the race or the individual. The education of the race by itself, independently of the ordinary course,

* M. de Serres, in his Lectures on Anthropology, at the Museum of Natural History.

+ Ross, Narrative of a Second Voyage, etc., p. 446.

I This fact is related by Pallas, Mémoires du Muséum, vol. xvii, p. 238. A Kalmuc saw a body of men thirty versts off [nearly twenty miles English], while the Russian general could see nothing even with a telescope. 
seems to us difficult to admit, since education, in this case, would suppose a triumphant struggle against the ordinary course of things. Every animal comes into the world as its parents came, or, at least, apparently so. If he brings with him, by inheritance, certain particular characteristics, they must necessarily in time become obliterated either by their own means, or by destroying all those who possess them (the case of hereditary degeneracy). In fact, if perfection in a race were possible by means of an individual, the consequence would be that very soon our descendants would be no longer in relationship with the circumambient medium, which would be an absurdity.*

As to individual education, it has an undeniable influence; but this does not suffice to explain such important differences. We never find that Europeans, who happen to be thrown among savages, attain to these peculiarly fine and delicate perceptions so special to many aborigines. And, moreover, the American residing in boundless forests, where the view is always restricted, has as piercing a glance as the Kalmuc upon his plain. The question of the education of an organ or a system by the individual himself will be cleared up, doubtless, one of these days, by attentive anatomy. And since we are upon the subject, let us remember that an important study still remains, hitherto merely glanced at,- - that of the influence which, for instance, the milk of an animal or a female of another race may have upon the development or the health of a white child.

The differences which we call physiological are very numerous; we shall, however, only quote two or three from among the most striking. The principal point, perhaps, is the peculiar smell of the Negro. This is so strong, that it even impregnates for some time a place where a Negro may only have remained for a few hours, and it is so characteristic, that it alone constitutes a grave presumption in matters of slavetrading; for Humboldt has stated concerning the Peruvians

* It would be interesting to discover if the fact related by Knox (The Races of Men, 1850, p. 271) is true; namely, that the sharpness of sight, which the Bosjesmans possess in a very high degree, is lost immediately on crossing the breed with the whites. 
what Le Cat and Haller said about the savages of the Antilles, that they could perfectly trace a Negro by scent, thanks to this odour; and it is, at the same time, a new proof of the sensitive perfection of the American race. This odour is quite independent of age, and sometimes is almost insupportable in young children; it is also independent of sweat, and, in fact, of all the means of cleanliness of which a Negro can make use.* It is due, according to all appearance, to a secretion from the same glands which, in the white man, give such a peculiar odour to the arm-pits; but this latter is absolutely different from that of the Negro. $\dagger$ With regard to this, we must not lose the occasion of noticing one of those contradictions into which monogenists have so often fallen, and, indeed, it could not be otherwise. "The dog does not come from the jackal," says M. Flourens, $\ddagger$ "for the jackal has such a peculiar smell, that it does not seem possible that, in this case, the dog should not have preserved some traces of it at least." Shall we reason in the same manner in order to make a special race of the Negro, and would this monogenist accept it?

Another very remarkable physiological peculiarity, and one quite as worthy of being noticed, since it has a certain effect upon physiognomy, upon the facies of a race, is a special mode of standing, consisting in holding oneself in a squatting position, the sole of the foot on the ground, and the thighs bent up against the hams, without the ischia touching the ground. This effect is what Cook called " a monkey countenance."

* Le Cat, Traité des Sens, 1744; Haller, Elementa Physiologia, vol. v, p. 179; Humboldt, Relation Personnelle, vol. iii, p. 229.

+ See Robin, Annales des Sciences Naturelles, 1815; Zoologie, vol. iv, p. 380.

\# Histoire des Travaux de Buffon, p.92.

$\S$ ["Face to face with the present position of metaphysical thought in England, that anthropology, which can find no higher employment for the human mind than the ascertainment of man's relations with the baboons, will find no place at all. . . . . We have no real fear that the consequences which may result from the practical application of this law (transmutation) will be prejudicial to religion, morality, or society. . ... But until the day comes when such a law shall be fully, entirely, and satisfactorily established, we must strenuously protest against the diffusion, even amongst the 'wider circle of the intelligent public,' of essays, the object of which is to render "Man's Place in Nature' closer to that of the brute creation." C. Carter Blake, Man and Beast (Anthropological Review, vol. i, pp. 154,161).-EDITOR.] 
We find nowhere that the Greeks, - the inhabitants of the ancient continent generally,- the Arabs, or even the ancient Egyptians themselves, have ever been accustomed to this position, which necessarily implies some anatomical modification, whether it be in the separation of the pelvis, the direction of the neck of the thigh-bone, or the torsion of the bones, etc.* This position seems, on the contrary, to have been always the peculiarity of the Melanesian races; it is the ordinary mode of standing among the inhabitants in the upper course of the Nile, and the Negroes of Africa and the Oceanic Islands. They place themselves thus in order to look at anything, to chat together, or to deliberate. The magnificent drawings which illustrate the account of the travels of the English Embassy to the Emperor of Abyssinia, $\uparrow$ represent this monarch as reviewing an entire army of infantry drawn up in order of battle, and all squatting in this manner.

The ancient Egyptians generally kept themselves either on their knees or seated on the ground, the legs brought together, and the knees touching in front of the chest, as thousands of statues, figures, and pictures show us. But their artists have just revealed to us that the people of Central Africa have always been as they are at the present day. The great painting of Beït-Oually, in Nubia, $\ddagger$ represents Rameses the Great as charging a troop of Negroes from Soudan; on one side, farther off, we see a Negro near a saucepan, preparing, doubtless, some food; he is squatting in the manner of which we have just spoken. In this place, as is often the case, the Egyptian artist has been clever in seizing a profile by its most significant characteristic. $\S$

Géricault wished at one time to make a drawing of an episode in the "Shipwreck of the Medusa," Coréard making

* See Sömmering, 1785, p. 42.

+ Sketches of Central Africa.

₹ There is a copy of it at the British Museum.

$\S$ We only know of one painting in which Egyptians themselves are represented in a like position; it is in the British Museum, and is on a tomb. It is a group of persons squatted behind a flock of geese. It is right to remark, however, that the artist may have been rather puzzled about its composition, more complicated than usual, and that the inartistic profiles of his figures, which almost cover one another, greatly diminish the value of the picture with reference to our subject. 
signs to an African chief who was seated on the sand; he placed in his composition a Negro squatting, but he drew him with one foot resting entirely on the ground, and the other bearing only on the extremity of the metatarsi. At that time Géricault had only a white man as a model; a Negro would have placed himself differently, with both his feet flat on the ground.

We might pursue the history of these physiological varieties ad infinitum,-it is a large field for the enquirer; and to mention one fact alone, the compared history of development among the different races of mankind has still to be accomplished, especially the history of the intra-uterine development of the Negro, and even partly the history of the first months of his aërial life.

III. If organism, operating normally among different races, presents such varities, why can we not suppose that it would hence show correlative differences in its morbid changes? should there not be, also, an ethnic pathology? This contains a large question, and yet it was scarcely thought of a few years ago. It seems to have been first proposed and studied by $\mathrm{F}$. Schnurrer in his treatise on Geographical Pathology,* in 1813, in which the author seems to have perceived imperfectly, in all its vastness, the matter which now occupies our attention. The book is divided into three parts ; the first is entirely geographical, the second entirely anthropological, and the third is given up to a description of maladies, commencing with two introductory chapters; the first describing the diseases of each zone, and the second, containing eleven pages, is a "Glance at the general Characteristics of Disease in each Race." "In fact," says Dr. Boudin, $\dagger$ in pointing out the novelty of these enquiries, "there are some races who show themselves completely rebellious to certain pathological forms, for which others, on the contrary, show a remarkable predisposition."

Two particular maladies have been pointed out in this point of view,-marsh-poisoning in all its forms, and yellow fever.

* Geographische Nosologie oder die Lehre von den Veränderungen der Krankheiten in den Verschiedenen Gegenden der Erde, in Verbindung mit Physicher Geographie und Naturgeschichte des Menschen, 8vo, Stuttgart, 1813.

† Traité de Géographie Médicale, 1857 : Introduction, p. 29. 
Africans are evidently, at least in parts, exempt from these two diseases, which only attack them with a very minor force. It has been said that the question of marsh-poisoning is still very doubtful; it was allowed that the Negroes were less exposed to its attacks than other men, but it was desired to enter the question of acclimatisation* into the calculation of facts. All the countries we know that are inhabited by blacks, being nearly all subject to the noxious influence of marshes, it was pretended that even stranger Negroes had acquired from infancy, in their own country, an immunity by which they benefited later in life, and even had the power of handing it down to their descendants. + It is thus that some have explained, for instance, the unhappy results of the English expedition to the Niger in 1841. Out of 145 whites belonging to the crews, the three vessels, after a navigation of about forty-nine days on the river, had lost 40 men (130 were attacked). Out of the twenty-five coloured men embarked in England, and who were mostly born in America, eleven were seized with illness, but not one of them died. $\neq$ This individual acclimatisation can only be either a fiction, or a proof in support of the ideas which we defend. In the presence of a morbid influence which shows itself and continues, two things alone can happen,-either destruction, or permanent (that is to say, specific) modifications of œconomy, in harmony with the ordinary manner in which this animal population continues to exist.

* ["The great question of acclimatisation has hitherto been treated lightly enough. ' A firm resolution not to be conquered by a malady,' says Malte-Brun, 'is, in the opinion of most doctors, one of the most efficacious preventives of disease. Our body depends on our intelligence. In every climate the nerves, the muscles, the blood-vessels, in relaxing or in stretching, in dilating or in contracting, soon take the particular state which suits the degree of heat or cold which is borne by the body.' Thus, according to this celebrated geographer, man has only to exercise his will in order to accommodate his organism to all the difficulties of a new temperature and a new climate." H. J. C. Beavan, The Acclimatisation of Man (Social Science Review, February 21, 1863.)-EDiTor.]

$\dagger$ Hirsch, Handbuch der Historisch-Geographischen Pathologie, § 10. With the author of this immense compilation we refer our readers (with reference to this relative immunity of Negroes from marsh-fever) to the works of Jobin, 'Tschudi, M`Cabe, Hunter, Arnold, Cameron, Heymann, Epp, Bartlett, Thomson, Tidyman (Philad. Journ. of Med. Science, vol. iii, No. 6), etc.

† Epidemiological Society, 3rd June, 1861; Medical Times and Gazctte, 29th June, 1861, No. 574. 
The yellow fever, exercising its ravages upon shores equally distant from whites and negroes, has brought very decisive arguments into the question. We know, in fact, that the whites suffer in America from the black vomit in all its violence; whilst the Negroes are not attacked by it, or if they are, its effects are insignificant.* A ferocious maxim, one worthy of the conquerors, has explained-since the sixteenth century-this prerogative, which the Spaniards had so much reason to envy, "If we did not hang a Negro, he would never die." $\dagger$ If some authors have timidly advanced the theory of a former acclimatisation $\ddagger$ with regard to marsh-poisoning, the greater number of observers, Fenner, Nott, and Bryant, ought to admit that there was, even in the constitution of the black man, an obstacle-otherwise absolutely unknown in his nature - to the manifestation of the yellow fever; $\S$ and that the black blood appeared to carry on this resisting force to the mixed breed, even if they were born far away. $\|$

An extremely interesting experiment relating to this immunity of the Negro from the yellow fever, was tried largely during the disastrous Mexican expedition, and the conditions of this experience ought to give it a capital value. At first, our soldiers paid a terrible tribute to this scourge, and then the French Government took up the excellent idea of profiting by the resistance of the Negro race to the black vomit. It

* [“In spite of 'previous acclimatisation,' a Negro regiment was almost entirely destroyed by chest disease at Gibraltar, in 1817, within the short space of fifteen months." Acclimatisation of Man (Social Science Review, February 21, 1863).-EDrTor.]

† Si no acontecia ahorcar al Negro, nunca moria.” Compare Herrera, Hist. Gener. de los Hechos de los Castellanos, dec. 2, Book m, chap. xiv.

$\ddagger$ Bancroft (Essay 273); Blair, Some Account of the last Yellow Fever Epidemic of British Guiana, London, 1850; Jackson; Hirsch, Handbuch der Historisch-Geographischen Pathologie, § 36.

$\S$ "It is a well-established fact, that there is something in the Negro constitution which affords him protection against the worst effects of yellow fever, but what it is I am unable to say."-Fenner. Compare Hirsch, Handbuch, § 36 .

|| "The smallest admixture of Negro blood, even though the subject be brought from a more northerly state, seems to be a potent antidote against the morbid poison."-Nott, Southern Journal of Medicine, February, 1847. "The coloured people resisted the epidemic influence better than the whites; and, I believe I may hazard the observation, that their degree in resistance was in proportion to the admixture of white blood."-Bryant, American Journal, April, 1856, p. 301. Compare Hirsch, Handbuch, § 36. 
asked for a battalion of blacks from the viceroy of Egypt, consisting of men recruited from the limits of Soudan, from Berber to Khartoum. It was not without anxiety that the issue of this physiological experiment was watched, since it did not happen, as in our laboratories, in anima vili. Some had confidence in the functional uniformity of the Negro race, as being beyond all local action; others believing wrongly, as we said, in a former acclimatisation of the only inhabitants of the western coast of Africa, expected to find that all these Negroes from the other side of the continent would perish. However, in spite of what they had at first said, they could very soon verify the almost complete immunity of the Negro battalion at Vera-Cruz.* It was the first time, if we are not mistaken, that anthropology has been directly applied in the Old World to social science. Some time ago anthropologists were consulted by the government of the Northern States of America upon certain questions of slavery, at the time when terrible dissensions were budding in the shadows of the distance.

* See Mémoires de Médecine et de Chirurgie Militaire, November and December 1863; Socièté d'Anthropologie, meeting of 19th March, 1864. 


\section{CHAP'TER V.}

\section{INTELLECTUAL AND PHILOLOGICAL VARIETIES.}

From time immemorial, common sense has enlightened mankind upon the intellectual differences which make one nation differ from another, and one race from another. Almost all nations, in admitting that they are superior to their neighbours, acknowledge thereby a characteristic difference between themselves and those whom they thus place below their own level. An overweening sense of vanity may possibly cause deception in this case; but this belief is, at least, based on a veritable fact,-intellectual inequality. There are, indeed, sensible and manifest differences, which no one will deny, especially those who seek in the literary monuments of a race for the history of its ideas and its tendencies, and those who have mingled with other nations, and who have examined their manners, their customs and their religion. "It is sufficient to have seen the blacks," says their most enthusiastic defender,* " to have lived some time with them, to feel that there is in them a humanity quite different to that of the white man." $\dagger$ Some persons have

* M. d'Eichthal, Lettres sur la Race noire, 1839, p. 15.

+ ["The Arabs say that Mohammed, whilst on the road from Medina to Mecca, one day happened to see a widow woman sitting before her house, and asked how she and her three sons were; upon which the troubled woman (for she had concealed one of her sons on seeing Mohammed's approach, lest he, as is customary when there are three males of a family present, should seize one and make him do porterage), said, 'Very well; but I've only two sons!' Mohammed, hearing this, said to the woman, reprovingly; 'Woman, thou liest!' thou hast three sons; and for trying to conceal this matter from me, henceforth remember that this is my decree,- that the two boys whom thou hast not concealed shall multiply and prosper, have fair faces, become wealthy, and reign lords over all the earth; but the progeny of your third son shall, in consequence of your having concealed him, produce seedis as black as darkness, who will be sold in the market like cattle, and remain in perpetual servitude to the descendants of the other two." This is the Arab theory of the Negro's origin, mentioned in What led to the Discovery of the Source of the Nile, by J. H. Speke, p. 341, London, 1864.-EnrTor.] 
wished to deceive themselves; they have wished to raise the Negro race to our own level, in the name of some sort of sentimental feeling, which, moreover, has always turned out to be a mistake. Many persons have been engaged upon them. Not being able to give them plastic equality, they had recourse to intelligence,--they wished to deceive themselves, like Desdemona, when she said,-

\section{“I saw Othello's visage in his mind.”*}

The Negro was declared to be our equal by the moral law, only with certain shades of distinction depending on some particular and transient circumstances which would soon disappear. It was announced that, in their turn, they would advance ideas, and would work at what is called progress, that is to say, "the increase of good on the earth." $\dagger$ "In proportion as work makes vital energy to predominate in the head," said M. Marcel de Serres in 1844, " these deeply coloured men, $\ddagger$ with crisped, woolly, or short hair, will tend in a manifest manner towards the white race,--will march with them in the path of progress." § And farther on, "This experiment has scarcely commenced, but it already shows sensible effects."' Unfortunately, the twenty years which have passed since these words were written, have not shown that they are true; and the challenge offered by an American has never yet been accepted, "Let anyone quote to me one single line written by a Negro which is worthy of being remembered." $\|$ They are not more advanced now than at the time when Mohammed refused them the gift of prophecy. I And, as Dr. Hunt remarks, there is cer-

* Othello, Act I, Scene 3. [Othello was, however, a Moor, not a Negro, and capable of a far higher delicacy of mental perceptions than the veritable " unbleached African." Perhaps one of the most absurd theatrical errors was committed when the part of Othello was acted by a genuine Negro, Ira Aldridge.-EDITOR.]

† Edmond About, Le Progrès, 1864, p. 15.

\# These are Negroes of whom he is speaking.

§ “De l'Unité de l'Espèce Humaine," Biblioth. Univ. de Genève, nouv. ser., vol. liv, p. 145,1844 .

|| Gliddon, Types of Mankind, p. 59. Carus has observed, that among the remarkable Negroes mentioned by Blumenbach, not one of them was distinguished either in polities, literature, or in any high conception of art. Compare Gobineau, De l'Inégalité des Races Humaines, vol. i, p. 122, 1853.

T See De Maillet, Telliamed, 8vo, vol. ii, p. 187, Amsterdam, 1748. For want of those passages of the Korán to which he refers, we give the whole 
tainly no means of civilising those who have been uncivilised for three thousand years, during which time they have been connected with the Egyptians, the Carthaginians, the Arabs, the Portuguese, the Dutch and the English.*. If it be objected that they have always been slaves, we may say our Gallic and German ancestors were so also; but we ask, Why do they continue to be slaves?

The merit of first endeavouring to distinguish races of men by characteristics taken from without the physical world, by the quality of the manifestations of their intelligence, is, perhaps, due to Linnæus. With this spirit of laconism, which led him to group in one simple and easy formula the characteristic facts which he desired to impress on the mind of the reader as being important, he endeavoured to determine, in a few words, the various tendencies of different races, and it must be acknowledged that he has at times been happy in this kind of synoptic classification. $\dagger$

of Maillet's remark on the subject:- "Mohammed was so struck with the difference between white and black men, that he did not hesitate to say, that God had made the first with white earth, and the latter with black. He did not imagine that men so different, not only in colour but in figure and inclination, could possibly be of one and the same origin. $\mathrm{He}$ observes, in another place, that although there have been prophets of all other nations, there was never one among the blacks; which shows that they have so little mind, that the gift of foresight, - the effect of natural wisdom, which has sometimes been honoured with the name of prophecy,-has never fallen to the lot of any of them." This passage is, besides, remarkable ; because this eustom of prophecy seems to be a special attribute of the Semitic race (compare Renan, Histoire Générale des Langues Sémitiques, 8vo, p. 8, Paris, 1855), and Mohammed, in making this distinction, declared almost a specific characteristic. In the translation of the "Evangile de l'Enfance," by G. Brunet (Evangiles Apocryphes, 12mo, Paris, 1849), there is this curious document (Jesus hadjust changed some children into rams in the sight of some women, who asked for their pardon), "The Lord Jesus having answered, that the children of Israel were, among other nations, like the Ethiopians; the women said," etc. This is merely a proof of the contempt which overwhelmed this unhappy race in the east.

* On the Negro's Place in Nature (Dr. Hunt, Anthropological Society of London, November 17, 1863).

+ See the table taken from the Systema Naturce. We know that Linnæus had adopted the geographical classification of human races.

\begin{tabular}{|c|c|c|}
\hline Homo & Americanus & $\left\{\begin{array}{l}\text { Pertinax, contentus, liber. } \\
\text { Regitur consuetudine. }\end{array}\right.$ \\
\hline " & Europæus. & \\
\hline " & Asiaticus. & \{everus, fastuosus, avarus, \\
\hline & Afer. & $\begin{array}{l}\text { Vater, segnis, negingen } \\
\text { Regitur arbitrio. }\end{array}$ \\
\hline
\end{tabular}


In proportion as modern knowledge has made us penetrate more deeply into the minds of races,-since we are no longer contented with studying them superficially in the ordinary manifestations of life, which we may call "common-place;" and which belong to nearly all countries,-we perceive that insuperable limits separate one set of men from another with regard to intellectual affinity, so that here, as in the case of physical characteristics, each race is almost to be distinguished from its neighbours. "Profound and unchangeable differences," said M. Paul de Remusat,* in 1854, " which would, perhaps, suffice of themselves to found definite and thoroughly limited classifications."

It was in order to point out a new branch of anthropology, a new and fruitful branch,- - that a work appeared which was destined to throw a bright light on the subject. It was necessary to explain these distinctions, and not merely to enunciate them. The merit in this matter belongs to M. Renan, who, in his treatise on the languages of the great Semitic family, has painted, from the most favourable characteristics, this humanity which is, morally, so different from our own, however like it may be in external form. The intellectual disparity of races is henceforward an undeniable fact.

The religious or moral system of a people being the highest manifestations of its intellectual tendencies, we see that the study of religions enters quite naturally into anthropology; it is a part of this comparable study of the human mind, unfortunately too much neglected, but which begins to take a place worthy of its importance in the world of science. $\dagger$ We do not wish to discuss theological or religious questions, the an-

* Des Races Humaines, in the Revue des Deux Mondes.

+ [It is, indeed, worthy of a place in science, though not apparently in the sense which is meant by our author. C. Carter Blake says, and says truly, "In zoology, as in all other methods of human thought, the sincere searcher after truth will reap some solid benefit for his labours if carried on in a fair and honest spirit. What science reveals to us, -and we know of no source of knowledge whence the revelation of the truth, as it is manifested in living nature, can be impugned,-what science teaches us, a simple-minded student will accept, that which the unbiassed evidences of his senses and the manifestations of his own consciousness tell him to be true." (C. Carter Blake, On the Doctrine of Final Causes, as illustrated by Zoology, Hastings Philosophical Society, meeting of January 13, 1864.)-EDITor.] 
thropologist ought to leave them to others. His duty is to endeavour to put himself outside the narrow circle in which nature has placed him ; to forget, as much as possible, his inclinations and personal sentiments; to look around him; to put the world in one view, and to endeavour to be the sole spectator of the same. Then a curious phenomenon will strike his gaze,-the chains of mountains and the rivers which separate the various races of mankind, will also separate different religions. Like the sea which breaks on the shore, every belief has seen its disciples, armed with the sword, or with the pacific weapons of persuasion, stop at certain limits, over which they are not permitted to pass. Of course, we only speak here of true proselytism, of real progress in religion in its form and spirit. Humboldt and Bonpland saw, one day, in the Cordilleras, a savage crowd dancing and brandishing the war-hatchet round an altar where a Franciscan was elevating the Host. Such neophytes are only called Christians in the Annales de la Propagation de la Foi,-they are not converts in the opinion of the anthropologist.

Pure monotheism seems always to have been the religion of the Semitic race. Most European nations, on the contrary, have professed from antiquity, a polytheism or a pantheism, more or less disguised, more or less acknowledged. In fact, by the side of those nations of Asia and Europe, where civilisation and religious ideas appear to have simultaneously been developed, although in different directions, we find other people who have neither religious ideas, nor gods, nor any kind of worship.*

Three vast regions of the earth, inhabited by people still in a savage state, appear to have remained, up to the present day, free from religious beliefs ; these are Central Africa, Australia, and the country around the North Pole,-that is to say, the

* ["The natives of Australia," observes Hasskarl, "are deficient in the idea of a Creator or moral Governor of the world, and all attempts to instruct them terminate in a sudden break up of the conversation. The Bechuanas, one of the most intelligent tribes of the interior of South Africa, have no idea of a Supreme Being; and there is no word to be found in their language for the conception of a Creator." (Force and Matter, by Dr. Louis Büchner, transl. and edited by J. F. Collingwood, F.R.S.L., F.G.S., F.A.S.L.). -EDITOR.] 
three parts of the world which are most difficult to explore,the only parts which have even not yet been thoroughly examined. And this is one consequence of this want of exploraration; it supposes a sort of sequestration from the rest of the world, which has not even succumbed to civilisation by this contact and imitation of which we have already spoken. Let us admit that relations were established by these people with their neighbours; they would soon have imported from the foreigner conceptions which would even then have never taken a form, on account of the small portion of intellect which nature had given to them.

Referring to the inhabitants of Australia, Latham acknowledges that the general opinion is, in fact, that they have not yet commenced to shape the rudest elements of a religion,* "an opinion," he says, "which causes the idea that their intellects are too sluggish even for the maintenance of superstition." "It is certainly true that, in the American expedition under Captain Gray, it was thought that some religious ideas could be perceived among them; but it appears from the same account that the song which constituted all this apparent religion, had been brought from far by strangers, and adopted by the natives,-doubtless, by other Australians, who had already been influenced by the Christian ideas of the white men, or the Buddhist principles of the Malays.

To relate the history of the introduction of an idea among a people is, in reality, to declare and prove that this idea did not exist there before, which is sufficient for us if we can be assured of the fact. The testimony of missionaries $\dagger$ is, besides, consonant with that which we have just said; and we may remark on the importance of assertions coming from men whose whole study is to discover, in the people whom they desire to convert, ideas analogous to those which they endea-

* I translate in this way the word mythology, used by Latham; it is the real translation. Every religion is necessarily based on a fable, for whoever does not practise it, "Mutato nomine, de te fabula narratur." [This is an assertion which our author has no right to make, and which certainly does not redound to his credit. We must earnestly protest against it. A moment's consideration, however, will satisfy most men that the translator's license has here been carried to a most unwarrantable extent.-EDiror.]

† The Reverend Messrs. Schmidt, Parker, etc. 
vour to propagate. "They have no idea of a Divine Being," says one of these men; "they appear to have no comprehension of the things they commit to memory,-I mean especially as regards religious subjects." - "What can we do," says another, "with a nation whose language possesses no terms corresponding to justice or sin, and to whose mind the ideas expressed by these words are completely strange and inexplicable?"”

As to Central Africa, we confine ourselves to relating a few facts relative to this want of religious belief, gathered from different points in the periphery of the vast triangle, almost unexplored and unknown, which is described by lines joining together Senegal, Zanzibar, and the Cape.

An American missionary,* who lived four years amongst the Mpongwes, one of the most important nations of Central Africa, the Mandingos, and the Grebos, and who knew their language perfectly, declares that they had neither religion, nor priests, nor idolatry, nor any religious assemblies whatsoever. Dr. Livingstone says the same thing concerning the Bechuanas. $†$ The Austrian missionaries, established upon the distant banks of the White Nile, have met with the same want of religion, the same void $\ddagger$ in the mind. In fact, among the Caffres, the name which they give to the Divine Being, as among the Hottentots, is undeniable evidence that they formerly had no idea of anything similar. This name is Tixo, and its history is too curious not to be related; it is composed of two words which, together, signify the "wounded knee." It was, they say, the name of a doctor or sorcerer, well known among the Hottentots and Namaquas, on account of some wound which he had received on his knee. Having been held in great estimation for his extraordinary power during his life, the Wounded Knee continued to be invoked even after his death, as being able to comfort and protect; and consequently his name became the term which best represented, to the minds of his countrymen, their confused idea of the missionaries' God!

\footnotetext{
* John Leighton.

† See Bertillon, Bulletins de la Société d'Anthropologie, March 15, 1860. [See above, p. 66, note.-EDiTor.]

I I had this fact from the mouth of $M$. de Lesseps, on his return from a journey to Khartûm.
} 
As to the Esquimaux, since 1612, Whitebourne wrote that they had no knowledge of God, and lived without any form of civil government. And we can add to this distant testimony the following lines from the journal of Sir John Ross, who lived for a long time in the midst of them. "Did they comprehend anything of all, that I attempted to explain, explaining the simplest things in the simplest manner that I could devise? I could not conjecture. Should I have gained more had I better understood their language? I have much reason to doubt. That they have a moral law of some extent 'written in the heart,' I could not doubt, as numerous traits of their conduct show, but beyond this, I could satisfy myself of nothing; nor did these efforts, and many more, enable me to conjecture aught worth recording. Respecting their opinions on the essential points from which I might have presumed on a religion, I was obliged at present to abandon the attempt, and I was inclined to despair."*

This extract is so much the more important for our thesis, since we perceive in every word the chagrin of a man who did not find in the hearts of others a fraternal echo to his dearest sentiments. It is, in truth, a difficulty peculiar to the study of questions of this nature. We must, therefore, be very careful in discussing the value of any testimony which may be brought forward, and to distrust those minds which begin by declaring $\grave{a}$ priori the universality of beliefs, hopes, and fears among mankind, as a natural consequence of the primitive unity of the human species. We must always examine most minutely the accounts of travellers to which we are obliged to refer. Thus, for example, it is evident that the older the evidence, the better it is ; but at the same time, the farther it goes back, the less chance there is that it emanates from an independent and impartial mind, free from all prejudice.

Happily, the exaggeration of these ideas must often suffice to put us on our guard against them, like the candid Jesuit, whose zealous but hazy faith thought it had discovered traces of St. Thomas's preaching in Brazil. $\dagger$ In an otherwise good

* J. Ross, Narrative of a Second Voyage, p. 548, 1835.

+ Emanuel Zobrega wrote to the Company from Brazil, in 1552 :- "The 
notice of the Esquimaux,* Dr. King says, "that these people have preserved, like many other uncivilised races, a vague remombrance of the creation and of the deluge, and that they believe in future rewards and punishments." In his religious zeal, Dr. King forgets that if the Esquimaux had been able to bring a confused tradition of even the deluge and the creation from the valley of the Euphrates, it was impossible it could have beon the same with a belief in future rewards and punishmonts, seeing that the Jews themselves never possessed this belief before their contact with Assyrian civilisation. We may read in Dr. Brecher's excellent work $†$ the whole history of the development of this belief in the immortality of the soul. If the German doctor wishes piously to prove that the Jews ought, morally, to have always believed in this immortality, at all events, his zoal has been ablo to invont real proofs, which in fact, are wanting. The famous scheol, which is mentioned so often in old Hebrew books, appears to be merely the kingdom of the dead, and not that of souls, like hell, Tartarus, the Elysian fields, and Paradise; the scheol is but an ideal representation of the tomb. Even at the time when the Jews had generally adopted the ideas of their neighbours, during the 'Talmudic period, the belief in the immortality of the soul, if it existed, was neithor completely clear nor well reasoned, since they refused all participation in a future lifo to thoso who denied the resurrection and the last judgment, "which was equivalent to entire annihilation." $\ddagger$ To believo this, is cortainly not to believe in the immortality of the soul, since they regarded eternal lifo not as a necessary consequence, but as a recompense for good principles, and having faith in them. Such an inconsistency is the clearest possible proof that, even at this period, these ideas had not undergone the change which brought them to the actual point of clearness. They wore

inhabitants acknowledge Saint Thomas, whom they call Zomé (changing the $T h$ into $Z$, according to their dialect); and they have a tradition that he once journeyed through this country." His letter is fully given by Nieremberg, Historia Naturæ, fol., Antuerpiæ, 1635.

* "On the Intellectual Character of the Esquimaux" (Edinburgh New Philosophical Journal, vol. xxxviii, p. 306, October 1844 to April 1845.

+ L' Immortalité de l'âme chez les Juifs, transl. by I. Cohen, 12mo, Paris, 1857.

¥ See Brecher, L'Immortalité de l'âme chez les Juifs, p. $\$ 1$. 
also not yet completely freed from the ancient belief which the Sadducees, besides, had not abandoned; they were the faithful preservers of the ancient faith, and the pure tradition of the sons of Israel. "They have the theory that the soul dies with the body," wrote Josephus,* " and consider that they ought to keep nothing but the law."

We must be pardoned for insisting so much upon this point; but it is of importance as regards our thesis to show that the belief in the immortality of the soul, and in a divinity, is not universal on the globe, that one general characteristic of humanity could not be formed from it, and that we ought even less to rely upon the existence of such ideas in order to establish a human kingdom. We have only spoken of people who are either entirely savage, or of Jewish opinions, which have long been lost in the past. Even in our own time, there are two hundred million Buddhists on the earth, who have reached a marvellous point of civilisation, who ignore, in the most absolute manner, the notion of another life and that of a divinity. Eugène Burnouf, whose ability no one will deny, has already said it; M. Barthélemy Saint-Hilaire, after much hesitation, which will remain as the seal of a firmly established conviction, has decided in the same way, in the last edition of Bouddha et sa Religion. $\dagger$ We quote his own words:- "There is not the slightest trace of a belief in God in all Buddhism; and to suppose that it admits the absorption of the human soul into a divine or infinite soul, is a gratuitous supposition which cannot even enter into the ideas of the Buddhist. In order to believe that man can lose himself in the God to which he is reunited, this God must first be believed in as a necessary commencement. But we can scarcely say that the Buddhist does.not believe in Him. He ignores God in such a complete manner, that he does not even care about denying His existence; he does not care about trying to abolish Him; he neither mentions such a being in order to explain the origin or the anterior existence of man, his present life, nor for the purpose of conjecturing

* Josephus, Antiquities, xviii, ch. 2, transl. by D. G. Génébrard, Paris, 1639. + Chapter upon the "Nirvâna." 
his future state, and his eventual freedom. The Buddhist has no acquaintance whatsoever with a God, and, quite given up to his own heroic sorrows and sympathies, he has never cast his eyes so far or so high." And the author adds the following lines, which have a direct bearing on anthropology, and which are like the sum of all we have just brought forward:"The human mind has scarcely been observed but in the races to which we ourselves belong. These races deserve, certainly, a high place in our studies; but if they are the most important, they do not stand alone. Ought not the others to be noticed, although they are said to be so inferior? If they do not enter into the hastily drawn outline, must they be disfigured by submitting them to over-strict theories? Is it not a better plan to acknowledge that old systems are faulty, and that they are not comprehensive enough in everything which they undertake to explain?*

The question of intellectual differences, like, indeed, all the other points in anthropological study, has largely exercised the inventive genius of monogenists, for it must be owned that all the efforts of imagination proceed from them. It is not more difficult to admit the development of one or twenty human species upon our planet, than the development of a single moss or sea-weed; they are phenomena of the same order, and equally beyond the actual limits of our knowledge; but this first step taken, anthropology opens itself to the polygenist as simple and easy; he follows, without any trouble, all phenomena, from cause to effect,--everything enters into one general order,-everything is marvellously simple, in spite of apparent complication. It is not the same with the monogenist; ruled continually by his theory, he goes on almost painfully, and at every step some new obstacle is raised to impede his progress. If he thinks he has conquered physical differences, psychological varieties start up; then will arise families of different tongues, quite as radically distinct and as difficult to explain; and yet it is in vain that the obstacle seems

* Barthélemy Saint-Hilaire, Bouddha et sa Religion, chapter upon the " Nirvâna," 1862. 
so great and insurmountable, it must be overcome, it must be passed in the name of an admitted principle, cost what it may so to do. Thus it is that monogenists have sometimes arrived at the most curious, but at the same time most unfortunate, results.

And if we wished to form sentiment from science, we should ask, which is the most reasonable, the most worthy, and the most consoling,- -whether to believe that we alone are perfect, and that nine-tenths of our brethren who cover the globe are disinherited; or to consider all these varied existences which we see around us as forming equal, if not similar, species, pursuing, each in its own way, a destiny, different, indeed, but not degraded,-not degenerated,-in certain points even better arranged than our own. "God," said Niebuhr, "has marked on each race of men their destination with the characteristic which best suits them ;" and the philosopher had already learnt by history that when civilisation has been suddenly introduced from without among a savage nation,* the consequence is an immediate physical degeneracy, that is to say, the destruction of the people which has wandered from its usual mode of life. The historian thus proclaimed a physiological law, which most monogenists are glad to forget,- that all degeneracy ends necessarily in death; it kills itself, and always at the tenth generation, if not at the first. No group of human beings, after two or three generations of unmixed existence, can be considered as degraded or degenerated, not more than we should admit that a young girl, attacked with crétinism in its greatest degree, had the characteristics of the Esquimaux or the Mongolian race. $\dagger$

We can see, even in a humanitarian point of view, - the point of view in which we refuse to place ourselves,- - that the polygenists have the advantage. The mind is not offended, and cannot be so, to see certain creatures possess some particular faculty to the exclusion of others. Does not

* Niebuhr quoted, in support of this, the Nalhkis and the Guaranis in the New Californian and Cape Missions. Schlegel (Essais, p. 341, Paris, 1841) declares, that most savage nations ought always to remain so by the will of nature.

† See Comptes renduis de l'Acadimie des Sciences, meeting of July 20, 1857. 
harmony obtain an absolute value from a necessary inequality of parts, whilst she herself restores to each part an equal value, in making them all co-operate towards the same end, the same action, in which are distributed great and minor parts,--some brilliant, some humble, some concealed ?*

That fine North American race, which is so much admired by all who have lived among them, will be no longer, according to Dr. Martius, $\dagger$ the worthy descendant of the first murderer, a collection of maniacs and insane folks, brought to that state by misery and the reprobation of God. We only see in them men endowed like ourselves, but more in harmony with the nature which animates them, having, of course, their imperfections like ourselves, but giving us also an example of great qualities, firmness, courage, patience, and an intense love of liberty. Whites and blacks may be slaves, but the American has never served a master. $\ddagger$ The Negro himself has his advantages; and we could not, perhaps, struggle with him about affective or hateful faculties. M. de Gobineau seems to us to be strangely mistaken in the portrait which he has attempted to draw of the black man; he has made his race

* "I maintain," says Courtet de l'Isle (Tableau Ethnographique du genre humain, p. 89, 8vo, Paris, 1849), "that human races are unequal in intellectual power, that they are, consequentiy, not susceptible of the same degree of development, and that each of them is called upon to fill, in unequal conditions, a mission marked out by Providence."

+ Doctor Martius is a curious example of the extravagances to which monogenist ideas may lead. In order to explain the moral character of the Americans, he is obliged to suppose a frightful cataclysm [great inundation] which happened, he cannot say when, and adds, "Is it the profound terror felt by those unhappy people who escaped from this awful calamity which, being transmitted without a diminished intensity to following generations, has troubled their reason, obscured their intelligence, and hardened their heart ?" Compare Morel, Traité des Dégénérescences de l'espèce humaine, 1857, and Discours Inaugural d' l'Académie de Rouen, 1857.

$\ddagger$ D’Orbigny saw the Charruas continue a war against the Spaniards (who decimated them) rather than renounce their much-valued independence. (Voyage dans l'Amérique Méridionale, vol. iv, Introduction p. 4. [Our author ought not to compare the northern Americans with the southern aborigines, giving to both of them, apparently, the same characteristics. The northerners are whites, and (supposing the Canadians and the north-western settlers are spoken of) worthy of his praise. We put the present Northern States on one side altogether, as the character given by our author cannot possibly apply to them. The Charruas, who are mentioned in the above note, are Indians, inhabiting the banks of the Uruguay in South America, and therefore, whatever may be their courage and love of liberty as aborigines, they cannot properly be classed with white inhabitants, who aro merely settlers.-EDITor.] 
hideous; it is only inferior in relation to ourselves; it is equal to some, and superior to others, not partaking, indeed, of all the advantages of the Iranian or Semitic races, but able to display other qualities which belong particularly to itself.

In the place of this spectacle, which is thus presented to our view, of degraded beings covering half the earth, we simply see, for our part, intelligence developing itself in each race, following certain directions and tendencies at the expense of others. These special tendencies are sometimes very remarkable. In his intercourse with the Esquimaux, Sir John Ross, whose observing mind we have several times had occasion to notice, found that they were nearly all good geographers. He put into their hands a pencil and paper (of the use of which they were certainly ignorant), and they drew with great correctness the bays, rivers, islands, and lakes of their country, as well as the exact spots where they had encamped at some former emigration. This is a curious contrast with most of the African and Arab peoples, who seem to have but a very vague idea of distance or time ; indeed, the difficulty of finding out routes among the inhabitants of Soudan, which we have ourselves experienced, has become almost proverbial.* Without going so far as all that, our neighbours, the Semites, differ from ourselves in the manner and quality of their mind to an extraordinary degree; on the one side is the Aryan, an analyst, a pantheist, given to the plastic or perspective reproduction of everything which surrounds him; on the other, the Semite, a sensualist, a monotheist, an iconoclast. If it is radically impossible for the Semite to follow us in the depths of metaphysics, his language even being opposed to all philosophic demonstration; in our turn, perhaps, we are less religious,that is to say, less solemnly struck by the universe. The thought of demonstrating God, and proving this thought, will never come to the Semite as it did to Bossuet, Fénélon, and

* Compare D'Escayrac de Lauture, Le Désert et le Soudan; Mémoire sur le Soudan, etc. [These people are not so very peculiar in this respect. Even in our own land, there is sometimes a good deal of difficulty in obtaining information about routes; and agricultural labourers especially are much given to scratching their heads and chewing the cud of meditation, ending with an indecision quite delightful to the tired traveller.-Eorton.] 
Newton.* The Semite feels God, if we may so express it; and, as if absorbed and astounded by this personified creative force, whose shadow presses on him, he does not understand the arts of reproduction, although among all the people who excel in it.

In fact, history itself will teach us that these tendencies are so much accused and so general, that they are found everywhere; in one place rising even above conquest, in another, modifying itself to imported religions. When a religion, in accordance with the genius of the men to whom it has been addressed from the cradle, passes from this race to another, it is necessarily modified. Pure monotheism, born in the east, has only conquered the west and the Iranian race by transforming itself to their pleasure. The Persians accepted Islam; but they have not been able to renounce this necessity for plastic reproduction, which is one of the characteristics of the Iranian family : a schism became formed, which authorised all the arts, and left in entire freedom that natural tendency which could not be smothered. Far more than the monsters in Isaiah's dream, the lions of the Alhambra were a terrible prophesy. Those who see them may read in their huge figures the vitality of a conquered nation, whose love of the living form invaded even the palace of the conquerors; and which were soon to make them fly. The race which flourished at Athens and at Rome only accepted Christianity, which also came from the east, by despoiling it of its original character ; and this religion would, at the present day, be incapable of making proselytes in that east where it first took its rise. The preaching of Mohammed was, as M. Renan has remarked, but a reaction of pure monotheism against degenerated Christianity, concealing but badly its polytheistic tendencies.

In truth, the psychological study of the human race is a new science, which has been examined into on some points, but not in all. To desire to sketch it would be to fall into the alternative either of doing what others have done perfectly, or to fall into error for want of necessary materials. We can only

* See Philosophice Naturalis Principia Mathematica, pp. 482, 483, 4to, Amstelodami, 1723. 
quote, as having been well studied,-first, the Iranian race, by all our moralists and philosophers; secondly, the Semitic race, by M. Renan; and thirdly, the American race, by Humboldt and Bonpland,* by d'Orbigny, $\dagger$ Morton, $\ddagger$ and Coombe. $\S$

II. The study of languages is connected, on the one hand, to the physiology of the human race, but more immediately still to the study of the varieties of the human mind, of which they are in some measure the organ. They can by this means assist also in classifying mankind into natural groups. But where the study of languages affects more especially the anthropologist, $\|$ is when it touches on the origin of the varieties of language, and of the primitive state (either intellectual or social) of the speaking man: when it endeavours to fathom the past each day farther back,-each day nearer to the origin. Thus bound together, the two sciences ought to have the same destiny; philology has had its monogenists and its polygenists. The first have been obliged to give way, overpowered by the number and the superiority of their opponents. They are done for; and the field remains free to the latter, who affirm, through their studies, the multiplied origin of human language, leaving the consequences to be deduced, or deducing them themselves. 1

One sole declaration will suffice us, that of the history of

* See Essai Politique sur le royaume de la Nouvelle Espagne, Paris, 1811.

† Voyage dans l'Amérique Méridionale.

I Crania Americana, Introduction.

$\S$ Mémoire on the preceding work.

II [Dr. Hunt, however, does not think that language is such an unfailing test as our author appears to imagine. He considers that language must be utterly discarded as the first principle of anthropological classification, and gives a far higher value to religion and to art, considering language merely as the third element. It is possible to change the language of a race; but apparently impossible to change either their religion or their innate ideas of art. See Hunt on Anthropological Classification (Brit. Assoc., 1863), Anthrop. Rev., vol.i, p. 383. “On ethnology, Professor Müller says, 'The science of language and the science of ethnology have both suffered most seriously from being mixed up together. The classification of races and languages should be quite independent of each other. Races may change their languages; and history supplies us with several instances where one race adopted the language of another. Different languages, therefore, may be spoken by one race, or the same language may be spoken by different races; so that any attempt at squaring the classification of races and tongues must necessarily fail." (On the Science of Language, R. S. Charnock; Anthrop. Rev., vol, i, p. 200.)-EDITOR.]

T See Chavée, Les Langues et les Races, 1862. 
Semitic idioms. "If the planets, whose physical nature seems to be analogous to that of the earth," says M. Renan,* "are peopled with beings organised like ourselves, we may presume that the history and the language of those planets does not differ more from our own than does the history and language of the Chinese." It is impossible to establish by a clearer and more striking image the individuality of the different families of language, not one of which owes its origin to its neighbours, and which have, probably, never been in one another's presence, except when they had already been formed, bringing with them their own characteristics, their fundamental and profound type, as unalterable by contact as is the physical type of the men who spoke them. These, in presence of others, may have been able to alter their traditions, thoir remembrances, their words, but these were never more than simple loans; we may be certain that these men were strangers one to the other on the day when they uttered their first words in their cradles.

We must limit ourselves merely to recording the result, which is, that each system of language is absolutely irreducible to others, both by its basis and its form; all born in human thought, it is true, but this thought following at each point a particular path, so that each of these systems, as M. Renan has said, only abuts on the others by the community of the aim it is intended to reach.

Certain families of languages do not differ solely by their constitution, they show special phonetic or physiological qualities; $\dagger$ that is to say, we can observe, in two different languages, varieties of the same order which is explained among animals, by the words barking, braying, cooing, etc. This is particularly the case with the strange language spoken by the clear-complexioned race of South Africa, probably much more widely diffused in former times than at present. It resembles no other known language, and consists in a clucking which has, they say, nothing analogous to it among any other nation on

\footnotetext{
* Histoire des Langues Sémitiques, p. 467, Paris, 1855.

+ See Prichard, The Eastern Origin of the Celtic Nations, edited by Latham, 1857.
} 
the earth. The English have characterised it by the names of sighing, or clucking, and also especially click language.* Here is a new difference, - a radical difference in relation to so many others, which decidedly forms, from these Bosjesmans, a people whom it is impossible to ally, it does not signify how, or under what aspect, to any other of the divisions of the great human family.

* "The sound of their voice resembles sighing." “Their language resembles the clucking of a turkey." Compare White, Account of the regular gradation of Man, p. 67, London, 1799. Appleyard, The Kafir Language, p. 3, 8vo, King William's Town, 1850. Morel, Traité des Dégénérescences de l'espèce humaine, p. 42, Paris, 1857. "The Kafirs have adopted some of the inflexions in use among their neighbours, but as a simple ornament to their speech, without attributing any special signification to these 'cluckings." -Is. Geoffroy- Saint-Hilaire (Correspondence). 


\section{CHAPTER VI.}

\section{THE INFLUENCE OF CLIMATE.}

Monogenists - starting from unity of origin as a fact, if not proved, at least accepted and unquestionable,-were necessarily led to discover a physiological explanation of the profound differences which we find at the present day among mankind, and which would have led them, according to monogenists, from one extreme state to the other, or from a medium state to the two extremes.

Now, it is necessary to remember that every question concerning influence implies a previous historic notion. We cannot establish that a modification is not produced in a body (here is humanity), except by comparing it with itself at two distinct moments of duration, more or less distant. When a monogenist admits as an origin one uniform human race, he places a term of comparison in the past, he gives an historical date more or less definite to this uniform human species. And it is because religious cosmogonies alone dare, at the present day, to arrogate to themselves the power of making history dart back to the commencement of humanity, that we shall always be much troubled by not seeing a theological influence as the basis of monogenist ideas; now, they say, however, that they have discovered the trace of this human uniformity upon which they rely, in order to prove this great historical fact.

In our own opinion, history is very far from commencing with mankind; it only goes back two or three ages before the invention of figurative language,-a more important and difficult language for man than articulated language, which was discovered long before, and at many different points. It is 
writing which makes the Asiatics and the lost people of Central America better than savages; and if we were asked for a specific distinction with regard to intelligence between mankind and animals, we should only be able to find it there. It will be seen later that we are far from denying the influence of a middle course ; but we maintain that every term of comparison is wanting at the present day to show that man, since the most distant historic periods, has ever shown less dissimilarities than now. Most monogenists, disagreeing about the whole system of modifying causes, agree generally in acknowledging that climates and hybridity have a decisive creative influence as regards races of men. These two kinds of influence alone deserve our consideration. We shall commence by climate, putting on one side, for the present, the study of the specious question of hybridity, whose part is so badly understood by those who believe that it creates varieties, when it can only weaken differences.

An important part in the means of alteration from one race to another has been given, by Hippocrates, to external influences. He seems to have been the first to point this out, in his Treatise on Air, Water, and Places.* "The form, colour, and manners of nations," says Polybius, "depend solely on the diversity of climates." $\dagger$ In general, the ancients believed in the immediate and sudden influence of climate, so much so that a stranger, at the end of a few years, would be completely changed and altered to the type of the inhabitants of the same place.

In our days, Cabanis alone has dared to go so far as this. $\neq$ Some monogenists have simply enlarged Grecian theories, and explained everything by the prolonged duration of the same influences. Others have supposed that local changes in the atmospheric conditions of the world, anterior to the actual epoch, were the cause. This is a sort of progress beyond the preceding hypothesis, in the sense that at least we must recognise

* Compare Cabanis, Rapports du Physique et du Moral, 13th year, vol. ii, p. 201: Knox, The Races of Men, p. 82, London, 1850 : Morel, Dégénérescences de l'Espèce Humaine, Paris, 1857.

+ See Beddom in English Cyclopoedia : see, also, Vitruvius, book vi, ch. i.

‡ Rapports du Physique et du Moral, 13th year, vol. ii, p. 294. 
the insufficiency of actually existing causes, in order to explain the great differences observed at the present day between men. Isidore Geoffroy Saint-Hilaire has agreed with his father upon the great question of the influence of the surrounding medium; but death seized him before he could apply these theories to mankind. However, the high position that his Histoire Naturelle Générale has taken in science obliges us to pause a moment on the subject of his opinions, which have, besides, easily triumphed over the ruins of Cuvier's school. And if we do not agree with all the doctrines propounded by the second Geoffroy, we are all the more satisfied, since, differing from the son, we incline more to the theories of the father.

Isidore Geoffroy believed in a decisive influence of the medium, but only under certain conditions. He believed that these influences are limited, as he himself calls it, every time that it relates to anything beyond the action of man, that is to say, on savage or free animals. In this case, the action of the medium, according to him, would be confined exclusively to the producing of varieties in form and in the colour of the skin,*-a form we never see varied in the same class of men; the colour of the skin,-which is sensibly the same among men, among whom the fair type is itself exceptional, and spread over a very small portion of the ancient north-west continent.

In every case, Isidore Geoffroy acknowledged that these variations are sometimes very inconsiderable; $\dagger$ and although they have in no way approached those which separate human races, we may be allowed to believe that the differences observed among savage species were, in his eyes, much less important. He has endeavoured, on the contrary, to compare insignificant clifferences among free animals with varieties much more marked, and much clearer than those shown by domestic animals, and therefore, doubtless, he wished to make a step towards the fundamental question of anthropology,

* Histoire Naturelle Générale, vol. iii, p. 319, 1860. We do not here quote the facts relative to the Barbary and Corsican stag (ibidem, p. 407), since they rest only on the negative assertion of an old author.

+ "Partout de petits changements, nulle part de grands." Hist. Naturelle Générale, vol. iii, p. 388. 
which was evidently at the bottom of his thoughts, and which he had for a long time resolved in a monogenist sense.

But domestic animals have quite special conditions, which do not allow the assimilation of these varieties with those which have been simply produced by natural forces. Cuvier* had already pointed out this difference, and rejected all assimilation between them and free animals. Without taking too much account of the reasons which impelled him towards such opinions, we believe that upon this point, at least, he was entirely in the right; as to the rest, Isidore Geoffroy himself furnishes us with weapons against his own theories. "Since nature, left to herself," he says, "does not give us witnesses of the great changes in the conditions of existence, it is clear that there only remains one means of seeing such changes, and of deducing therefrom the effects upon organisation,-it is to force nature to do what she would not do voluntarily." $\dagger$ All the condemnation of this system of Isidore Geoffroy is contained, in our opinion, in these last words. As for ourselves, we reject, in the most absolute and formal manner, the connexion which some have desired to make between man and the domestic animals. Man is a sociable animal, like many others; but he only becomes exceptionally a domestic animal when he falls into slavery. The domestic animal is a being drawn from the normal state, and constrained by man. He is constrained by nature to obey the influence of his master alone, -an influence infinitely variable. It resembles itself no longer; the habit of obedience does not even leave it its will; it ceases to be a personality, and becomes a mere machine, producing for the benefit of another person.

Domesticity has certain characteristics of degeneracy; the animal loses its activity, it becomes less eager, and assimilates itself more; it becomes almost incapable of subsisting alone; it vegetates; together with its personality it has lost this resistence to the ambient medium, which is the necessary characteristic of the species, the condition of the nisus formativus;

* Recherches sur les Ossements Fossiles, 4to, vol. i, p. 59, 1831.

+ Histoire Naturelle Générale, vol. iii, p. 389. 
it modifies itself to everybody's will. Its organism may be considered as being in a state of unstable equilibrium, so that the least influence causes this organism to vary, and with the least possible delay, to a considerable degree.* But when man ceases for an instant to be attentive in directing these modifications, when he forgets himself for a moment, naturealways vigilant and ready to seize upon her rights-destroys all this human edifice, and recalls the animal to a type which may be called normal, but which is not the type of the stock, since nature, acting on an organism endowed, as we have just said, with the wonderful malleability and ductility acquired by domesticity, immediately and naturally modifies the animal, which is restored to liberty, by the power of the new medium into which it is cast.

Nothing of the same sort takes place with mankind. This does not mean, however, that he cannot also be reduced to a state of domesticity. + Slaves, indeed, are nothing else; and all that is wanting in order to place them in comparison with animal domesticity, would be the history of a race of Ilotes, which has always been free from any mixture, and has continued so during a time equal to that which separates us from the first conquest of the dog, the sheep, and the ox, upon the high table-lands of Asia.

Let us, then, leave all comparison $\ddagger$ between man, free to come, to go, and to choose his own food,-and domestic animals. Let us return to those who live free, and say, once for all, that if we stop our progress with so many details concerning these

* "What would be thought of a breeder who took Norman colts or Flemish calves to the high lands of the Alps and the Pyrenees, and then expected to see them reproduce (their training having been finished) all the pure characteristics of the original races?"-Isidore Geoffroy Saint-Hilaire, Histoire Naturelle Générale, vol. iii, p. 307.

+ See Verneuil, Bulletins de la Socièté d'Anthropologie, February 2, 1860.Bonté, ibidem, August 6, 1863.

$\ddagger$ ["A priest who has drunk wine shall migrate into a moth or a fly, feeding on ordure. He who steals the gold of a priest, shall pass a thousand times into the bodies of spiders. If a man shall steal honey, he shall be born a great stinging gnat; if oil, an oil-drinking beetle; if salt, a cicada; if a household utensil, an ichneumon fly" (Institutes of Menu, § 353). Thus, apparently with regard to comparison, the Hindú considers insects to be the lowest form of animal life, into which moral criminals are to pass after death, according to their doctrine of metempsychosis.-EDITor.] 
comparisons, it is from a kind of respect for the character of certain learned men who have thus treated anthropological science. We believe very little in biology, or in demonstrations by similarities. Every animal, every organ, every anatomical element, has its own life, its own laws of birth, development, nutrition, and reproduction. At the commencement of science, everything is clear and easy, like the cellular theory, for instance, in the elements of anatomy; but every day the laws of life (we might say, the laws of nature) are multiplied and complicated; every morning the searcher after truth must expect to discover some phenomenon which will disturb the scientific belief of the night before. "Every evening," said one of the masters of science, "our best prayer is to form afresh a synthesis of the sciences."* Well, if modern anatomy has taught us that the initial phase of the development of the egg differs according to the animal, $\dagger$ even as nothing resembles less the development of certain bones of the face than that of their neighbours, how shall we dare to compare any animal with man? Having said this, let us return to the influence of climate upon wild or free animals.

Isidore Geoffroy quotes, with complacency, the instance of the Corsican and African stag taken from Europe to these two countries scarcely twenty centuries ago, which form at the present day two clearly distinct varieties. From that the author of the Histoire Naturelle Générale argues rapid and sensible modifications, caused by the action of the medium. But,

* [Why will some scientific men persist in separating, so strongly, religion and science, as if both could not be practised? This is what the "master of science" appears to think. Each student of science may well apply the following lines : "It is your duty to go on steadfastly, unwaveringly, ohne Hast, ohne Rast, conscious that you interpret, to the best of your finite ability, your conceptions of the truths of science, equally conscious that whatever may be the immediate result of your labours, they must eventually fulfil the aspiration which tends ad majorem Dei gloriam."-C. Carter Blake On the Doctrine of Final Causes (Hastings Philosophical Society, meeting of January 13, 1864).--EDITOR.]

† Robin, Mémoire sur la Production du Blastoderme (Journal de Physiologie, p. 358, 1862).

I It is thus that we do not see realised in man that general law which decrees that animal species are large in proportion to the continent which they inhabit; the mean size of the mammalia, in particular, is regularly proportional to the extent of Australia, America, the ancient continent, and the bottom of the ocean. 
first of all, the evidence of this fact is simply negative; the old authors, who denied the existence of the stag in Corsica and Africa, were perhaps simply ignorant of it. Then, this introduction, if it did take place, was perhaps performed by means of animals which had been kept in domesticity or captivity for many generations, and consequently, were easily able to change their mode of life directly they recovered their liberty, as we have already said. However this may be, it is simply man himself whom it is necessary to examine, without comparing him to any animal, and without misleading ourselves with the connexion of climates, generally compared too hastily, and with regard to mere equality of temperature.

It is sufficient to run over, in Humboldt's Cosmos, the lengthy enumeration of circumstances which make up a climate, in order to understand that all the comparisons which our minds may make between any two regions of the world are, at least, rash. The analogy of two climates is rather a sort of experimental notion, which can only be reasonably deduced by the similarity of the biological as well as the meteorological phenomena of every kind in the two regions to be compared. And when climates shall have been able to change a white man into a black (a fact we energetically deny), must we also lay to the charge of meteorological influence the clear moral aptitude and profound differences of the various species of mankind? Shall we admit that a little more cold or heat will alter the intellect? and why not language?

But we are not the first to doubt all these marvels. Bacon* and Albint fairly doubted the effect of the sun on the colour of the skin. Camper, who admitted that all varieties come from external influences, acknowledged, and with good faith, that the influences which we can appreciate are not sufficient

* Compare Mitchell, An Essay upon the Causes of the Different Colours, etc. (Philosophical Transactions, 1745.)

+ "Sole colorari homines non dubium, eosque autem ut nigrescant non constat." Albinus, De Sede et Causa Coloris LEthiopum, p. 12. He also says, still speaking of Negroes, that they are coloured, "quod suum parentes colorem in liberos propagant .....; xthiops fomina si cum mare æthiope rem habuerit, xthiopem, ni quid forte natura ludat, gignit ; alba si cum albo, album."-Ibidem, p. 10. It is in some manner the permanence of a declared type. 
to explain fully either the prominent jaw-bone in the Negro, the cheek-bone in the Kalmuc, or the obliquity of the eyes in the Chinese and the Malay, etc. We can declare the same about all the other peculiarities of the same order,- the flattening of the nose, the crisped state of the hair, the colouring matter which we find even in the arch of the palate in the Negro, etc.

We owe a very good observation to Camper: "The black colourwhich is noticed in the natural parts of both sexes, and even in white individuals, clearly proves that our reticular membrane has its colour only from the blood."* This fact alone should have long ago given a more rational impulse to researches on this subject. If-putting all these hypotheses on one side, for all that we can bring forward has no other value-if we wish to study in a positive manner the influence of the sky upon man, we have only in reality one resource,-it is to shut ourselves up in the limits of history, to study the effect of the migrations of which it tells us, and to see whether man, transported far away, does become modified, and how this modification takes place. Then we shall find two answers to these questions, which form together a kind of anthropological law.

LAW.- In historical times, either man (we mean a society of men) who is taken far from his medium does not alter his type, or he entirely disappears.

What nation has been transformed? We cannot answer, even with history in our hand; we know not of any. And yet, the short period of time embraced by the records of mankind would be quite sufficient if it were true, as Isidore Geoffroy thought, that we could conclude from animals to men, and that two thousand years would have been sufficient to alter fundamentally the genus stag. + It is a well-known fact, that the inhabitants of the Island of Bourbon, who were colonists established in the high lands for two centuries, have preserved intact the purity of their blood. $\ddagger$ The Spanish and Portuguese

* Dissertation Physique sur les Differences des Traits du Visage, p. 17.

+ See above, p. 85.

I Yvan, De France en Chine, p. 175, Paris, 1853. [“M. Périer has mentioned, according to Yvan, the beauty of the inhabitants of the island of 
families established in Brazil, and who have carefully avoided foreign marriages, have lost nothing, it is said, of their original characteristics.* The Icelanders have not become Laplanders in their own island, and they have now been established there eight hundred years; they are as fair and German-looking as at first. The Dutch have prospered at the Cape under the name of Boers. They say that at Cochin and Malabar there exists a Jewish tribe, which has been established there for a long time, and which traces back its origin to the captivity; it has remained pure, $\ddagger$ and as similar to the inhabitants of the Jewish quarter at Cairo, as to the Jews in Leonardo de Vinci's Last Supper, and in the pictures of the Flemish school.

Indeed, among ourselves in Europe, have not the Irish preserved, under their foggy and cold sky, that southern nature which is revealed in their taste for certain arts, their small height, their black hair, the vivacity of the women, and the indolence of the men? Now, here is another order of facts,man is not altered by emigration. Perhaps these facts are not very conclusive to all people, either on account of the difficulty of observation, or the short period which they embrace. They must be taken just as science offers them to us, and we must give our attention solely to reckoning the conclusion from the value of the premises.

We now arrive at the second term of the law which we have laid down,- - that man, transported to another country, eventually disappears. The theory which we thus form is of considerable importance. It has even received a particular name, it has been called the Theory of the non-Cosmopolitanism of Man. It is at the present day defended in France by Dr. Boudin, with as much energy as talent. In this matter, facts are abundant enough, and they at once take a considerable

Réunion, who descend from a few couples only, and yet have known how to preserve their purity of blood" (An Inquiry into Consanguineous Marriages and Pure Races, Dr. E. Dally; transl. by H. J. C. Beavan, Anthrop. Review, p. 97, 1864.-EDitor.]

* White, Account of the regular Gradation of Man, p. 112. Morton, Crania Americana, Introduction. Prince de Wied, Voyage au Brésil, rol. ii, p. 310. Bory de St. Vincent, Essai Zoologique sur le genre humain, vol. ii, p. 20.

+ Desmoulins, Histoire Naturelle des races humaines, p. 162. Indigenous Races of the Earlh, p. 585.

\$ White, Account of the regular Gradation of Man, p. 104. 
significance; and this is determined by figures, so that we must acknowledge that in most cases each race is by its nature attached to the ground which supports it, and that it is not with impunity that it oversteps its limits.

It is because a foreign climate has in general a really destructive influence, producing degeneracy among emigrants, that is to say, a parallel morbid alteration of both the intellect and the body, that we always see the same races moving about in the same areas, and disappear when they pass them.* If the Semite, who has left Yemen, has come to pasture his camels near the shores of the ocean, opposite the Fortunate Islands, it is because he and his animals find in the Riff the same conditions of life that they did by the Nile and the Isthmus of Suez. Whatever has been said about the Jews and some other races, not one of them seems to be really cosmopolitan. To admit that a Jewish tribe, thrown into the midst of a black population, has become black by the sole action of the climate, is to admit that there were no conversions, no adoptions, and no sexual unions contrary to the law of Moses; and in this way the philosophic editors of the Code Napoléon, as well as daily medical practice, teach us what to think. For our part, we only see in these transformations of Jewish families, established far away, the result of the absorption of the type of a small group of emigrants by a population which outnumbers them. The Jew has disappeared; the language has been transmitted like the belief, and also the nape.

The acclimatisation of man, as well as of the wild animal, takes place only when he finds the conditions of existence sensibly identical with those in which he has been created. Beyond that, nature punishes him for having overstepped the limits which she had assigned to him, and within which he ought to continue to move his organism in relation to this defined medium. The domestic animal, on the contrary, by reason of this malleability of which we have before spoken, accommodates itself in general very conveniently. And the

* W. Edwards, Des Caractères Physiologiques des races humaines, p. 14. Niebuhr (transl.), Lectures on Ethnography, vol. i, p. 374. 
varieties which it shows on recovering its liberty, are of themselves a proof that it has been under a different sky to that of its original country.

Such is, in our opinion, the sole manner of explaining at the present day, in a serious and general point of view, all climateric influences. We must render justice to some monogenists, that they have perfectly understood the real part taken by these influences. Blumenbach calls them causce degenerationis; and here the German anatomist, in defending, like Prichard, the specific unity of the human race, raises himself above the English anthropologist, without, however, reaching what we believe to be the truth. Prichard, inclining to the belief that humanity is entirely descended from the Negroes,* acknowledged, consequently, a kind of causce perfectionis, that is to say, an ascending march of phenomena, where his predecessor had only seen an inverse march. Now, this ascending march of phenomena is difficult to reconcile with the notion of the specific unity of man. Every species, in fact, is necessarily constituted by reason of the defined space in which it ought to move. It is unreasonable to suppose that elsewhere the same organism and the same species can meet with more favourable conditions of existence.

In Blumenbach's opinion, all races are unhealthy deviations from a primitive type, of which we are the representatives ; $\dagger$ so that nine-tenths of the human kind are, according to him, composed of degenerate individuals. Blumenbach did not know that one of the essential characters of degeneracy is the limited development of its produce, that is to say, the disappearance of the race at a more or less distant period. $f^{\circ} \mathrm{We}$ ask ourselves only how monogenists, who all partake more or less of Blumenbach's opinions, and who nearly all pride themselves on moral and humanitarian sentiments, can consent to

* John Hunter also thought that man was originally black; he had remarked that domestic animals become white by age. Compare White, Account of the regular Gradation of Man, p. 100. Hunter thus confounded men with domestic animals. We have already said what must be thought of this connexion.

+ Compare Morel, Dégénérescence de l'espèce humaine, p. 5, Paris, 1857.

¥ See abore, p. 73. 
lower in this manner the number of human beings who are worthy of this name? Is not the best part, if there could be one in the case of science, played by the polygenists, who consider that other races are special entities, pursuing an end, which is their own and not ours, and dividing with us the planet, inaccessible in all its extent to the Iranian; just as certain kinds of animals, likewise, cover the globe with different species? Climate, we have said, has a decisive influence upon a man taken to another country; it must only be understood in the sense of this influence, and we have seen that it is generally a pernicious one.* It makes itself felt in the physical and moral nature of man, both deeply and superficially.

We may point out among the most simple and the most profound climateric influences, the sun-burn, the study of which is so interesting in anthropological study. We know, at the present day, that the sun is far from being always the cause of it; that a bivouac at night has as powerful an action in the same manner, and that the north-pole explorers found that their hands and faces were browned under a northern sky. $\dagger$

Are these not facts which will diminish the decisive part which has so long been given to solar heat in the production of colouring matter in the Negro? $\ddagger$ The colour of sun-burn

* Climateric influences act probably upon wild animals in the same. manner; it must be remarked, however, that a captive animal and a man, taken to another country, are not exposed in the same.degree to the action of the new medium; conditions are not similarly altered as regards both of them. Sometimes the man, sometimes the animal, will have most chances of resistance; the one being always obliged by his master to submit to an intellectual government, approaching as much as possible his former state; the other, abandoned to himself, and drawn fatally into the new habits which he sees around him.

+ See, on this point, Boudin, Géographie Médicale, vol. ii, p. 15, Paris, 1857. Annuaire du Bureau des Longitudes, p. 230, 1833. G. Pouchet, Des Colorations de l'épiderme, 4to, Paris, 1864.

‡ [Dr. Waitz, in his Introduction to Anthropology (translated and edited by J. F. Collingwood), gives an explanation concerning the colouring matter in the Negro, which is very curious, but with which, however, he does not agree; viz., " that in hot climates the amount of oxygen inspired is insufficient to change the carbon into carbonic acid, and that the unconsumed carbon is deposited in the pigment-cells of the skin. . . . . It is, however, difficult to admit that the browning of the skin in our climate in summer is produced by the same causes as the black colour of the Negro, and that it would only require a greater intensity and a longer duration to become so entirely." Part. I, sect. i, p. 35.-EDrTop.] 
does not even seem to remain in the layers of the epidermis, in which the normal colour is found. Indeed, we must remember, that it is always easy to distinguish a sun-burnt nation, since individuals who, for some reason or other, are but seldom exposed to external influences, like the women, are infinitely whiter; children are quite white when born, but as soon as they go much into the air, they become brown.

Unfortunately, the action of climate upon a man taken from his own country is not merely a case of sun-burn. And medical statistics have shown, in treating on the different races of mankind, the dangers of changing one's position on the surface of the globe, even if it takes place in the sense of isothermal lines. We find from the results of careful inquiries made in the English colonies at the Antilles for about forty years, that the black population is continually diminishing, the number of deaths being to that of births : : $28: 24$. Under the tropics, northern organisations are much disquieted, life changes its aspect, and its course is much more rapid. The glandular system governs;* man becomes " more sensible to pleasure, and less disposed to activity;"† his mind loses its vivacity. Those noble faculties, which have made the white man the monarch of creation, become weakened, and that especially in some colonies where government is obliged to entrust everything to Europeans.f Dr. Barnard Davis lately announced to the Paris Anthropological Society, $\S$ that one of his friends, Dr. J. A. Wise, after thirty years residence in India, had never been able, after numerous inquiries, to find any descendants of a European in the third generation.

Our temperate regions are to the Negro what the tropical zone is to the European. Even at Gibraltar,\| the Negro

* The precociousness of the genital functions is in direct relation with this general fact.

+ W. Edwards, Caractères Physiologiques, etc., p. 14. "The tropics alone produce the combination of infantine grace with the full development of female maturity." Smith, Natural History, etc., p. 190. See, also, Cabanis, Rapports du Physique et du Moral, vol. ii; and Davy, Account of Ceylon. These two authors in particular have quite appreciated these changes.

‡ Boudin, Géographie Médicale, vol. ii, p. 150, 1857.

$\S$ Meeting of November 7, 1861.

[See above, p. 59, note.-EDrror.] 
contingent that was employed in the English army paid a heavy tribute to death.* On the contrary, official documents for 1861 tell us that, at Sierra Leone, $†$ the respective mortality of English and Negro soldiers was as follows :-

\begin{tabular}{lccccccc} 
& & & \multicolumn{4}{c}{ Deaths per 1000.} \\
Marsh fevers & - & - & - & - & $410 \cdot 2$ & $\ldots$ & 2.4 \\
Dysentery & - & - & - & - & $41 \cdot 3$ & $\ldots$ & $5 \cdot 3$ \\
Liver disease & - & - & - & - & $6 \cdot 0$ & $\ldots$ & $1 \cdot 1$
\end{tabular}

It is an indubitable fact that, in general, the mortality of an emigrated population is in an inverse ratio to the distance they are taken. $f$ During many years the island of Ceylon was occupied by Hindú troops (from Madras and Bengal), Malays, Negroes and English. The mortality of these races respectively was, $12,24,50$, and 69 .

This is so clearly a biological law, that we again meet with its application even in certain particular cases. Concerning the yellow fever, for instance, Townsend has thus laid down a rule,- "The mortality to the new-comer from the cooler latitudes may be said to be in an exact ratio to the distance from the equator of his place of nativity." \$ Daniel Blair\| has given the following statistics, according to his observations of the same disease, made in British Guiana, from 1827 to 1835 :-

$\begin{array}{lllllr}\text { Natives (West Indian Islanders) } & - & - & - & 6.9 \\ \text { French and Italians - - } & - & - & - & - & 17 \cdot 1 \\ \text { English, Scotch, and Irish } & - & - & - & - & 19 \cdot 3 \\ \text { Germans and Dutch - - } & - & - & - & - & 20 \cdot 2 \\ \text { Scandinavians and Russians } & - & - & - & - & 27 \cdot 7\end{array}$

* It would appear from the documents collected by Nott (Two Lectures on the Natural History of the Caucasian and Negro Races, Mobile, 1844, compare Boudin, Géogr. Méd., vol. ii, p. 144), that as we advance towards the upper part of the Northern States, madness becomes very frequent among the Negroes. It reaches the proportion of one case of insanity among twenty-eight sane persons in Massachusetts and Maine. 'We hesitate in acknowledging climateric influence, because the number of cases seems to increase relatively to the degree of instruction among the people; not that madness depends on education, but because it finds out a great number of cases of which we should otherwise have been ignorant, as often happens in the east among a less enlightened people.

+ Compare Boudin, Bulletins de la Société d'Anthropologie, August 1, 1861.

¥ Compare Boudin, Traité de Géographie Médicale, 1857, Introduction.

$\S$ New York Medical Journal, p. 399, February 1831 (see Hirsch, Handbuch der Historisch-geographischen Pathologie, § 35, p. 1).

II Some Account of the Last Yellow Fever Epidemic of British Guiana, p. 59, 8vo, London, 1850. 
The epidemic of 1853, at New Orleans, allowed Barton to make a scale of mortality on the same principle, and absolutely comparable, and which would take away all doubt in this respect, if any existed.*

* Barton, Report of the Sanitary Commission of New Orleans for 1853, p. 248, New Orleans, 1854 (see Hirsch, Handbuch, etc., § 35). He brings forward several pieces of evidence in the same question. They seem to us too decisive, in a polygenist point of view, for us not to give the entire list of his quotations: Romay, Diss. sobre la Fiebre Amarilla, etc., Habana, 1797: Arnold, Treatise on the Bilious Remittent Fever, etc., p. 26, London, 1840: Zimpel, Jenaische Annalen für Med., i, p. 68: Dickinson, Observations on the Inflammatory Endemic incident to Strangers in the West Indies, etc., p. 13, London, 1819 : Ferguson, Notes and Reflections, p. 150, London, 1846 ! Dickson, Philadelphia Med. and Phys. Journal, iii, p. 250 : Lallemand, Das Gelbfieber, etc., p. 121. [Schomburgk, A Description of British Guiana, etc., p. 22, London, 1840.-EDITOR.] 


\section{CHAPTER VII.}

\section{THE INFLUENCE OF HYBRIDITY.}

WE must regard hybridity in a double point of view, as being able or unable to give an indication of the real value of different human races, as compared with the acknowledged natural groups in the greater number of zoological classifications; and on the other hand, we must study hybridity, belonging, as has been asserted, to the creation of new races.

It has been said, we repeat, that all men being able to reproduce one with another, the genus homo only constitutes one single family. That this argument should hold good, it was necessary to be proved that among animals (for thence it was that it was borrowed) two well acknowledged species, more different even than two human races, should never be prolific one with the other. Now, this is far from being the case. Isidore Geoffroy Saint-Hilaire, who has treated this subject in a masterly manner in his Histoire Naturelle Générale, acknowledges that animals belonging to two different genera can, by a union, produce a mixed breed, which, consequently he calls bigenerate hybrids.

So we will not give ourselves the trouble of contesting, as some polygenists have done, the universality, of reproduction between all races of mankind; we will not ask if every degree of combination has been observed,-the union, for instance, of an Esquimaux with a Negro, an American with an Australian, a Tartar with a Bosjesman. Let us admit, what is, perhaps, hardly the truth, that all races produce one with another,-we will admit all this; and yet it will prove nothing in favour of the monogenists who have brought forward this fact, since we 
henceforth know that there is no basis in this universality of reproduction for a serious argument,-since we know that two distinct species, two genera, in fact, can produce cross-breeds. This faculty of reproduction has had too much importance given to it,-it is only a function, that is to say, a physiological character quite improper for classification; the existence of bigenerate hybrids shows this sufficiently. It is a bad characteristic, because it is not a constant one; because either the man or the animal does not bear it in him, and that a given uniformity of circumstances is necessary in order to reveal this characteristic to an observer. It is the same with animal forms, which do not countenance in any manner such an observation; it is sufficient to recall the alternating generations of the invertebrata. Where shall we place all these agamous animals? how shall we class these proscolex and scolex, which have no sex, and which will never have one? Instead of the idea of fecundity, which is insufficient to characterise a species, we must substitute another, that of the development of the produce. If everything shows us that zoosperms, proceeding from very different animals, can equally fecundate any given ovum, -if we even admit that we have no good reason for rejecting the theory that each ovum can be impregnated by different kinds of zoosperms, it is very easy, on the contrary, to account for the fact that offspring will have no chance of life, except so far as the two parents show a sufficient identity, but which we cannot regard as fit to characterise species.

As the produce of two organisms, a descendant ought always to be considered as the result of two united halves fitted together, and combined one with the other. If the two halves are identical, the animal is like its progenitors in everything. If the two beings, who have endeavoured to unite themselves, are too dissimilar, the two forces cannot combine, and there is either no produce, or it is arrested in its development from the first moment of its embryo life. If the two forces, or the sum of the two forces, have a certain amount of common direction, they can produce a new being, but an imperfect one, and which will not have all the conditions of existence like its parents; it will not have genital power, and consequently will 
not be fitted to become the founder of a series of individuals similar to itself, succeeding it through time, "naturally, regularly, and indefinitely."*

Putting on one side the power of reproduction, we must attend solely to the union of different human races with regard to vitality of produce, and let us see what observation will teach us on this subject.

Jacquinot states, that "one can scarcely quote any cross between Australians and Europeans." When the ancient inhabitants of Van Diemen's Land, reduced to the number of two hundred and ten, were taken from Flinder's Island, not only had the union of the women with the unscrupulous convicts been unable to form a distinct race, but only two adults were found who were the produce of these unions. $\dagger$

"The Mulattoes," says Nott, "are the shortest-lived of any of the branch races; when they unite amongst themselves, they are less prolific than if united to one or other of the branches.f" This assertion is especially true concerning the cross-breeds born of Negroes and inhabitants of the north of Europe. At Java, crosses between Malays and Dutch appear not to be able to reproduce beyond the third generation." $\$$ "The half-caste of India," says Warren, "comes to a premature end, generally without reproduction; and if there are any offspring, they are always wretched and miserable." $\|$

We must say another word about Isidore Geoffroy SaintHilaire's opinion on the important question of cross-breeding in mankind. After having reproached Cuvier, and with reason, with having often, in the interest of particular views, admitted, as regards mankind, a flagrant contravention of the biological laws which his genius proclaimed for other animals,

* Words borrowed from the definition of species by Isidore Geoffroy, Histoire Naturelle Générale, vol. ii, p. 437. "The act which appears most natural to living beings who are perfect, and who are not abortive, nor produced by spontaneous generation, is the production of a being like themselves, the animal producing an animal, the plant a plant, so as to participate in the eternal and divine nature as much as they can."-De l'âme, book ii, chap. iv, § 2 , transl. by Barthélemy Saint-Hilaire.

+ Nott and Gliddon, Indigenous Races of the Earth, p. 443.

\$ Nott and Gliddon, Types of Mankind, p. 373, 1854.

$\S$ See Boudin, Géographie Médicale, Introduction, p. 39.

II See Morel, Traité des Dégénérescences. 
Isidore Geoffroy seems to us to have, in his turn, fallen into a contradiction of the same kind. He especially calls hybrids the crosses which occur from the cross of two different species, and he remarks, besides, that hybrids have generally tolerably decided characteristics, which are partly those of the father and partly those of the mother; so that the offspring, he adds, can resemble one more than the other, but not exclusively either of them: the cross is always to be found in it. On the contrary, it is not always so with the cross between two varieties of the same species; the produce has often the characteristics of both its parents, but very frequently, also, it resembles one of them exclusively.

For these beings who are the offspring of two varicties of the same species, and who very fiequently reproduce entire the type of one of their parents to the exclusion of the other, Isidore Geoffroy reserved the name of homoïles. Well, we ask him this, -in taking, as an example, the offspring of a union between a white and a black, shall we find in it the characteristics of a homoïd cross? Will it never resemble exclusively one of the two founders? Are not the characteristics of the Mulatto perfectly represented, perfectly defined, and always medium? Are not exceptions, if any can be quoted, of extreme rarity?* In the name of this consistency, ought not Isidore Geoffroy to have seen in a Mulatto something besides a homoïd mongrel, and to doubt even more that the different races of mankind constituted only varieties of the same species?

However, let us examine into hybridity so far as it.may serve to produce new, or modify existing races, as Blumenbach and Flourens have admitted. $\dagger$ Let us only remark that these two authors, like most monogenists, in placing hybridity, as the modifying cause, in the same rank as climate or medium, commit a great error. Hybridity, even in giving it the creative power which some have desired, goes entirely into the second rank, for it supposes a pre-existing plurality. It can only act, in the end, by weakening differences, by creating a middle

* Périer, Sociétè d'Anthropologie, meeting of April 21, 1861.

+ Des Races Humaines, 1845. 
term to two extremes. It cannot of itself produce variety of origin, it is the consequence of it, and we shall see that the part it takes on this matter is extremely restricted.

White* supposes a colony composed of an equal number of blacks and whites; then he tries to find out what will happen in the course of time, by supposing that a thirtieth part of them die and are born each year. He arrives, by his calculations, at the following results : in sixty-five years the number of blacks, whites, and mulattos will be equal; in ninety-one years the whites will only form one-tenth of the total population, and the blacks one-tenth; in three centuries, there would not remain one hundredth part of them, either black or white.

This proposition is true, theoretically speaking; it is practically false : it rests upon what we may call an unstable equilibrium. In the physical world we may, by care, happen to put an ellipsoid in a state of equilibrium on the extremity of its greater axis, or a cone on its apex; these are also unstable equilibria, but the least cause intervening, the smallest movement, and the balance is instantly destroyed. If we admit into White's theory a birth which does not take place, or an unproductive union, the conclusions are overturned at once; a part of the new generation will preserve the primitive type, $\dagger$ and this portion will be much more considerable than White imagined. When the facts of arrest of development, quoted above, are not sufficient to prove that a mongrel breed cannot subsist by itself, can we anywhere find one? Do we find a people preserving for centuries a medium type between two other types which gave it birth? We see them nowhere,just as little as we see a race of múles. The fact is that such a hybrid race, intermediate to two defined types, can only have a subjective and ephemeral existence.

The definition of the word type, both in natural history and in the particular case in which we are engaged, is rather a difficult matter, and which we can feel much better than wo can express it in writing. When we have seen a certain number of men belonging to one race, the mind, without any

* Account of the Regular Gradation of Man, p. 146.

+ Compare W. Edwards, Des Caractires Physiologiques, etc., p. 29. 
particular study, takes from each a number of general characteristics, and forms from them a sort of ideal being, to which it refers the real beings which it may henceforth see, and with which it identifies those who have a sufficient amount of similarity with this being.*

We have seen in the preceding chapter that, as regards historic times at least, a type invariably reproduces itself through time and space, when it does not succumb to the new climate in which it is about to live. If we admit, however, that two types may have met with a harmony of influences, a medium in which they can both live, we say that-even with all the care that may be taken to mix them-we shall always find, whatever White may say, black people and white people, if these races were black and white originally; and this by reason of laws which we think we can shape, and whose demonstration will be as positive as that of the domain of history.

Law 1.-A medium type cannot exist by itself, except on the condition of being supported by the two creating types.

LAw II.-When two types become united, two phenomena may arise: 1. Either one of them will absorb the other; or, 2. They may subsist simultaneously in the midst of a greater or less number of hybrids.

These two laws are only, in fact, the formula of the principles which Prichard $†$ himself laid down long ago, and which are held also by the editor of the Ethnological Journal, $\ddagger$ by Knox, $\S$ and by William Edwards. $\|$

* Individual distinctions can only, then, be based on the alterations of type, in characteristics which are not those of the supposed ideal. It hence results that, if we have lived with a stranger who has all the characteristics of his race well marked, we think that we see him while travelling among his fellow countrymen.

+ "It is one of the clearest facts in the animal, as well as in the vegetable world ; all races generally reproduce and perpetuate themselves without mingling and confounding one with the other."-Prichard, Histoire Naturelle de l’Homme, vol. i, p. 17. Compare Morel, Dégénérescences de l'espèce humaine, p. 2.

¥ Third number. Most of the articles in this remarkable production are unsigned.

$\S$ "No race will amalgamate with another; they die out, or seem slowly to be becoming extinct." Compare the Ethnological Journal, p. 98. Fis.

\|" "We arrive at the fundamental conclusion that it is useless for people belonging to varieties of different races, but neighbours, to ally themselves together; part of the new generation will always preserve the primitive type."-See Courtet de l'Isle, Tableau Ethnographique, p. 77. 
By reason of these laws, we find that nowhere can a medium race either establish itself on the ruins of two creating races, or replace them, and live by itself with an independent existence, formed entirely of hybrids which propagate among themselves. In fact we have laid down a rule that conditions of development are very much restricted among hybrids, and that they can only go on decreasing in their descendants, if they are capable of producing any. The crossed race will only exist in the condition of being supported by the two creating types remaining in the midst of it. If the value of this law is only deduced from a negative fact,-that is to say, from the absence on the surface of the globe of any real hybrid race existing by itself on a certain extent of territory,-we shall find, as regards the second, a great number of positive facts.

When two types unite, we said, a double phenomenon may be observed; either of these two types will absorb the other, or they may subsist simultaneously, one near the other. The first case ought to be the most frequent; but it is the least appreciable, because it does not leave sensible traces. We must endeavour to discover in history the remains of a people who formerly existed, and who have since disappeared. Thus, the colony of Nubians, taken to the banks of the Phasis by Rámases, have left no trace of their sojourn among the inhabitants of the land. It is the same with the Greek colonies of the Mediterranean coasts.* The Normans have only left, on the coasts of Labrador, their engraved steloe; $\dagger$ their race has not remained. The primitive Turkish and Asiatic type has likewise disappeared from Europe. This has been attributed to the introduction of Georgian women into the seraglios, and it is, perhaps, a reason only too readily accepted. It is, indeed, very natural that the repeated introduction of Georgian and Circassian women into the hárems should deprive the descendants of the conquerors of their original characteristics ; but if this were the case, the Turks of our days would, from continued unions with

* Latham thinks, however, that he has discovered some vestiges of the Phœnician race in Africa and Cornwall. Compare Knox, The Races of Men, 1850.

† [Small columns, having neither base nor capital.-EDrTor.] 
the same race, have become real Georgians and Circassians themselves. It has not been so, however, because the harems are recruited in Europe as well as in Asia, and even then the fact would only be applicable to families of high position. The truth seems to be that the real Turkish blood has nearly disappeared, and has been encroached upon and replaced by the old blood of the country, either Macedonian or Thracian.

We are ignorant of the laws which govern the disappearance of one race in the sight of another. Sometimes it happens very rapidly; sometimes it does not show itself. The complex conditions which rule it enter into the great order of facts which Darwin has so ingeniously classed under the name of the struggle for existence. They have always seemed to us to present a complete analogy with the disappearance of certain animal species before others, the steps of which disappearance history sometimes allows us to measure; so that there seems to be a curious similarity between the great fluctuations of nations and of animals upon continents. We are almost tempted to say that the invasion of the West by the Barbarians, the black rat, and the field mouse, is the triple expression of one and the same biological law. The American population retrogrades, like certain animals ;* that of the Australian coasts has disappeared; and we believe that the Negroes of Africa themselves will be called, at some distant period, to give up their place in their turn.

We do not know any more about the conditions which allow two types to subsist indefinitely one near the other: must we attribute this resistance to the country, or the races which are always before them? Why, if the Normans have disappeared in America, Italy, and Asia, should they still remain in Normandy, few in number, it is true, but always the same, and perfectly described by Linnæus, when he said of the Goths in the Scandinavian peninsula, "They have smooth, fair hair, and the iris of the eye is of a bluish colour."' Even when

* It is the case with the hippopotamus and the lion.

+ Thus, at least, Buffon translates "Gothi corpore proceriore, capillis albidis rectis, oculorum indibus cinere-cærulescentibus."-Linnæus, Fauna suecica, p. 1 . 
cross-breedings take place between more than two races,even when these various influences are mixed together, struggled with, and assisted in a thousand ways, so that the question has become almost inextricable to the anthropologist, in the midst of the varied produce resulting from all these combinations, we are astonished to see here and there individuals who have the absolute and complete character of one of the original stock. Whilst there remains among a people a considerable amount of mixed blood, we may always expect to see some one appear who will have the pure characteristics of the race which was believed to be extinguished, and mingled for ever with the blood of others.*

The most remarkable instance which can be quoted about these crosses, and at the same time the easiest to notice, is that presented by England, where two races live side by side, mixed together, without one having absorbed the other since the time of Strabo, Tacitus, and Julius Cæsar. England, isolated from Europe, ought necessarily to be a fertile field for the anthropologist, and it will be there where the history of historic and pre-historic races will soonest be made. Eminent men work at it with ardour; and the certainty of remounting, through archæology and palæontology, to the first races which invaded England, at a time when the use of metals wais unknown in the west, makes this study one of the most interesting of the present day.

Two distinct races divide Great Britain, or, at least, representatives of two races are found there; and in the midst of an immense number of intermediate individualities, the least accustomed eye will not fail to distinguish these two fundamental types, as different as two men with white skins can be. One of these races is composed of tall, strong, powerful men, with transparent skin, and blue eyes ; $\dagger$ the other, with a more tawny complexion, has black, curling hair. $\ddagger$ The first were formerly called Caledonians, the second Silurians, very like the

* By virtue of the law which makes us find a family likeness in an individual after it has been absent, or rather hidden, for one or more generations. + "Rutilæ comæ, magni artus."-Tacitus, Agricola, ii, § 11.

I "Colorati vultus et torti plerumque crines."-Idem, ibidem. 
Iberians of the Spanish peninsula: the first, of Germanic, or northern origin; the second, of Celtic, or southern origin. Nobody denies, at the present day, that these two races are well characterised, and every day one can meet perfect specimens of them in England. We may quote certain districts where the Silurian, Iberian, or Celtic race, as tradition wills it, are dominant;* for example, in the north-west of Glamorganshire, in the outskirts of Merthyr, and in the Vale of Neath. $\dagger$ Mr. John Philips finds them equally abundant in the Danelagł district, between Leicester, Nottingham, and Derby, with the same characteristics, "black eyes and hair, uniform, or rather, dark complexion."§ Among these two races there are of necessity a considerable number of cross-breeds who, allying themselves among one another, or to the pure types, produce varied results, and in this manner unite the two groups by a multitude of inappreciable shades of difference.

Such is also the case in France. Edwards $\|$ has divined it almost by inspiration; and M. Périer $\llbracket$ has powerfully added to his presumptions, by examining more attentively all ancient documents which treat on the inhabitants of Gaul. M. Broca, in the Mémoire which inaugurated the proceedings of the Paris Anthropological Society, ** has proved in the clearest possible manner, that if we draw a line passing by Cherbourg and Nice, $\dagger+$ we shall divide France into two distinct zones as regards the appearance and height of the inhabitants. In the south-west, the ancient Celtic population is of small height, as

* Idem, ibidem.

+ See Latham, Celtic Language, p. 371. J. B. Davis and J. Thurnam, Crania Britannica, p. 53. Garnet, in the Transactions of the Philological Society. R. Cull and Latham, in the Edinburgh New Physical Journal, 1854. Périer, Fragments Ethnologiques, Paris, 1857.

I J. Philips, see British Association, 1849.

$\S$ The name itself of this district shows, however, the habitation of these parts by the Scandinavians.

II Compare W. Edwards, Des Caractères Physiologiques des Races Humaines. Paris, 1829.

I See Périer, Fragments Ethnologiques, Paris, 1857.

** Recherches sur l'Ethnologie de la France (Mémoires de la Sociétê d'Anthropologie, vol.i, p. 1). See, also, the discussion which followed the reading of this paper (Bulletins de la Société d'Anthropologie, meetings of July 21 and August 4,1859$)$.

$+\dagger$ We may remark that this line is precisely perpendicular to the climateric parallels which divide France. 
is proved by the great. number of military exemptions.* In the north-west, in the region which was always encroached upon by the fair and powerful races of the north, the result is quite the contrary. Here, then, are two distinct races : the one, formerly mistress of the west, and then pushed to the extremity of the continent; the other, leaving its forests and encroaching on the rest,- - both differing as much as possible by physical aspect and by moral aptitudes, but now filling up their numbers, so to speak, by each other's help, and working together for the glory and prosperity of their common land.

We must not, however, give a general meaning to these last words, and thus extend their meaning to all cases of ethnic cross-breeding. The two united terms must not be too dissimilar, so that the two branches may reunite as regards progress. This is essential; and if we have endeavoured to prove that the hybrids of distant races do not possess all the necessary conditions of animal life and of propagation, it would be easy to find numerous proofs in order to show that, generally, the intellectual conditions of hybrids are not much more sątisfactory than their physical condition, since the two intelligent organisms which are there combined do not show a decided similarity.

Doctor Tschudi† says, in speaking of the Zambos (hybrids from aborigines and Negroes at Lima), "As men, they are greatly inferior to the pure races; and as members of society, they are the worst class of citizens :" they alone furnish fourfifths of the criminals in the prisons of Lima. Mr. E. G. Squier $\ddagger$ has made almost the same observation about the Zambos of Nicaragua. In his part of the country, the union of Spaniards with these same Americans, seems to have only produced degenerate men, who show no capability whatsoever for perfection or improvement. In fact, it is on account of these same principles that M. de Gobineau $§$ has set himself to prove at

* [The standard in France is, we believe, five feet.-EDrTor.]

+ Peru, 1846.

I Nicaragua: its People, vol. ii, p. 153, New York, 1852.

§ Essai sur l'Inégalité des Races Humaines, Paris, 1852. 
length that the mixture of races necessarily conducts mankind to degradation and universal debasement. Cabanis had the same ideas on the subject.*

The supposition which Cabanis and M. de Gobineau have taken up will, doubtless, never be realised. To admit that all human races can reach a complete hybridity, would be to admit that each race is cosmopolite, which it is not. But at least it remains true, that when two very different races are united, we must not hope for anything good or durable from their union. The same phenomenon happens, with the simple difference of intensity, when two different species of animals are united. So the monogenists are astonished at such a result in man, "a result quite contrary," says one of them, $\uparrow$ "to what one generally expects in crossing a race.” $\ddagger$ The astonishment of the learned man, of whom we speak, is explained easily enough by the ideas which he holds of human races, where he only sees degenerated varieties of the original type, preserved by the European in its primitive purity.

It is evident that in this monogenic hypothesis, which we shall not touch on again, the union of one of these degenerated races with the pure stock would be a sort of hygid consanguinity, and therefore favourable to the offspring. Here there would happen something analogous to the practice of the peasants in the crétin districts, who try to struggle against the scourge by secking for marriages in the plains, in order to give purer blood to each generation. In a more general manner it is evident that if we suppose two sets of people born of the same stock, and that one of them, after various fortunes, after having undergone fatal influences, should unite itself with the other, which had remained unaltered, it is evident that the

* Rapports du Physique et du Moral, vol. i, p. 484.

+ M. Morel, Traité des Dégénérescences.

¥." All races of mankind intermix, they are fertile, producing cross-breeds, mulattoes, mestizoes, etc., which again are productive. All human races constitute, therefore, on physiological principles, but one species, which is here identical with genus humanum." So thinks Professor Rudolph Wagner, but his arguments are not very satisfactory. He refers varieties of race in a great measure to climatic influence. See Creation of Man and Substance of the Mind (Anthrop. Rev., vol. i, p. 229).-EDITor.]

$\S$ Compare Bulletins de la Socièté d'Anthropologie, vol. iii, p. 175. 
produce of such a union ought to tend to reproduce in its purity the primitive type.* If it is not so with the union of different races of men, the reason is simply that they do not directly descend the one from the other; and from this debasement of produce there results a new proof in favour of the ideas which we are defending.

It remains for us to speak of hybridity, as applied to the propagation of a deformity or a monstrosity. We know that when we experimentally unite one of this class to the other, two individuals whose organism has equally deviated from the usual type, "nothing is more difficult than to prevent these mischances from being done away with." $\dagger$ A stronger reason, then, for the same when one of these individuals alone is deformed, which happens always in a state of nature. The races which we can thus produce are a kind of experiment which exist, but which it would be illogical to deduce can exist naturally. Because we make in a laboratory oxygenated water, or mixtures of hydrogen and chlorine, must we admit that these bodies are to be found united in nature? Quite the contrary; we deduce from their instability that they do not, and cannot thus exist in a natural state.

* In applying these principles to family consanguinity, we may say in a general manner, that it will be favourable or not to the offspring according to the state of the parents. If the parents are perfectly healthy, and exempt from all commencing degeneracy, they can only give birth to children at least as healthy as themselves. If one of the two parents is tainted with a commencement of degeneracy, the descendant, in his quality of offspring, will perhaps bear the trace of this degeneracy, but sensibly weakened. If the two parents are separately tainted with a different commencement of degeneracy, one or the other ought to continue it in the child, only in a lesser degree. But if the same degeneracy has already tainted both the parents, the offspring will show it in a greater degree, and will tend towards entire disappearance.

† Flourens, Histoire des Travaux de Buffon, p. 180. 


\section{CHAPTER VIII.}

SPECIES.

WE have now arrived at the limits of the task which we proposed to attempt, and we hope, after what has gone before, that we shall be able to arrive at some scientific conclusion.

After having endeavoured to establish in the introduction the route we had to follow in anthropological studies, we gave an account of the system of purely philosophic researches, putting every foreign or prejudicial idea on one side, and, resting on facts and on mathematical reasoning, we have endeavoured to apply these principles. We endeavoured at first to prove that man was not a being as foreign and superior to the rest of animal nature, as certain naturalists have thought, taking themselves, the first from among men, as the point of comparison. We have considered the inferior races, and we have shown that between these and the first animals the distance was neither absolute nor well-defined; that man came into the zoological series, and that he only forms definitively a separate family. Changing our direction, we abandoned this acquired knowledge, and we passed on to the study of varieties among men; we found them profound, indeed, and of every description.

Then came the study of the influences to which man may be subjected. We saw that hybridity did not play any serious part in this, since it could only weaken pre-existing differences. On the other hand, we have acknowledged that in the limits of time accessible to our knowledge, nothing justified the hypothesis, that climate had such an extensive influence in changing man so as to make the differences which we may observe be- 
tween ancestors and descendants such as would suffice, in any other zoological group, to characterise distinct species.

In regarding man as a separate kingdom, we are, by this fact, exempted from applying the same rules as in zoology; but, by proving that he comes into the zoological series, we have implicitly proved that he must be submitted to the same laws. Science cannot have two different modes of proceeding: it must follow the same paths in the same subjects in order to arrive at comparable results. It is the only truly philosophic road: nature is one, and the work of the modern sciences is precisely to tend towards unity. The most diverse phenomena in the hands of analysts compare and assimilate themselves to the rays of a spirit of synthesis ; magnetism, electricity, light, heat, motion, everything is mingled and linked together so well, that we know not how to make a distinction any more.

The pure and simple adoption of the law of organic unity brings us to the following proposition:-

Proposition.-Either we must admit different species in the genus Homo, or we must entirely reform zoological classification.

This last hypothesis will mean, then, that the works of Linnæus, Cuvier, De Blainville, and the two Geoffroys, will be of no value, and that we must commence anew the great work of classification upon the same basis which we wish to adopt in anthropology. Of the two terms of the preceding proposition, the second merits particular consideration. Zoological classification has been created and established by the greatest thinkers of which humanity can boast; even more, independent by its nature from all religious influence, it has been freely done, and without prejudice, as every scientific question ought to be, by means of facts and reasoning. It has not always been so with the works of those who desire that man should be an exception to universal nature, and beyond the limits of the animal kingdom. Zoological classification need not be reformed,-it is that of the genus Homo.

We touch now on the much discussed and controverted question of species, and at the same time on the question of the origin of man. We do not believe, as many eminent men have done, that this origin must eternally be concealed, that 
man will never be permitted to tear the veil from this statue of Isis. Let it suffice us to say that we are about to enter on slippery ground, where we shall only find as few resting places as the stones of a ford half destroyed by a torrent. And since we shall only find here and there the fragile aid of one hypothesis against so many others, in order to assist the consequents of our reasonings, is it a reason for drawing back? We do not think so.

Every period of a science has its own tendency; at given moments the efforts of all tend involuntarily towards one sole end,-one question absorbs all, and all partial solutions tend to the same general solution. At the present day, the great question in natural history is that of species; inquiries are ardently pursued, and materials are produced from every side, -opinions are mooted, and objections raised. We have only to call attention on this point to the works of Isidore Geoffroy, Morton, Nott, Godron, Broca,* Darwin, Fée, etc. The question of spontaneous generation is but a phase of the same discussion, an episode in the work of the birth of time.

Some people have made a sort of bugbear out of this word spontaneous generation, or rather, spontaneous genesis. $\dagger$ And yet, here is one of these truths to which, we think, we shall be led by the observation of facts and by reasoning. The great harm of examining into the question is to be strangely mistaken as to its bearing, and inclined to restrict its limits. It has, in fact, been said, that every day genital organs are discovered in beings whom it was thought were reproduced spontaneously. This is a specious argument to which Plutarch has long ago done justice. A person, whom he brings forward in one of his books, asks, "Which had the first existence, the egg or the hen ?" and concludes that "it was evidently the hen." Even in treating lightly on this subject,-in making it a familiar conversation, the Greek physician was, however, not mistaken about the importance of the matter. "So that," answers one of the guests, "with this little question of the

* [On the Phenomena of Hybridity in the Genus Homo, edited by C. Carter Blake, F.G.S., F.A.S.L.-EDitor.]

+ Compare G. Pouchet, Pricis l'Histologie Humaine, § 5. 
egg and the hen, we raise, as with a lever, the great and dark question of the generation of the world."*

That the animals which we know all reproduce by eggs, is possible, although it has not been proved, but this is not an important point; we want to know if all the animals which we are able to observe do not remount necessarily, in a more or less direct manner, and at a more or less distant period, to a spontaneous beginning. + The difficulty is everywhere the same,-everywhere we arrive at that immense obscurity which envelopes the origin of life on the surface of our planet; but it is essential in every case not to give to the phenomenon of spontaneous beginning any other signification than it ought to have. We must not believe, for instance, that matter is formed by the agglomeration of parts which do not yet live in a perfect being, having already all its organs distributed and proportionate, uniting in one living whole. This would be to cast ourselves on the field of an absolutely improbable hypothesis. Histology teaches us that each animal, its instincts and intellect included, is at a given moment merely a mass of amorphous matter, which, at a later period, will form itself, or in the midst of which will be spontaneously developed an anatomical element, that is to say, an organised body. To admit spontaneous genesis, then, is simply to admit the formation of organic amorphous primitive matter apart from an already living body, at the cost of and in the heart of which can be born the initial anatomical element of one of these animals, very properly called protozoa. We can even ask, whether this latent primary life, this atomic life, has not always been the ruling life on our planet. $f$ And since, when account is taken

\footnotetext{
* “Ac Sylla quidem sodalis noster, fatus nos parva quistione tanquam instrumento ingentem et gravem de origine mundi quæstionem subruere." Qucestionem Convivalium, book ii, quest. 3; transl., edited by F. Didot, 184.1.

+ Buffon said that (Suppléments, vol. iv, p. 335) this method of generation is not only the most frequent and the most general, but the most ancient, that is, the first and most universal one. Plutarch (Quost. Conviv., book ii, quest. 3 ; transl., edited by F. Didot, 1841) makes the same remark : "Proinde probabile est primum ortum ex terra gignentis perfectione ac robore absolutum fuisse, nihilque indigentem hujusmodi instrumentis, receptaculis et vasis, qualia nunc ob imbecillitatem natura parit atque machinatur parientibus."

I It must not be forgotten, that organic substances are supposed to have been found even in the formation of certain aërolites.
} 
of everything, we are almost entirely ignorant of the conditions necessary to the fecundity of any primitive embryo, excepting certain physical conditions of temperature, liquidity, etc.; and as, on the other hand, nothing authorises us to believe that the laws existing at the origin of life on our planet have since been abrogated, we see that, if we must necessarily conclude a spontaneous primitive genesis, there is nothing irrational in admitting, until we know farther on the subject, the persistence of the phenomenon.

Let us return to the subject of species, which, however, we did not quite leave in speaking on the subject of spontaneous generation. Isidore Geoffroy wishes to advance slowly in this matter, and only when facts become patent to all. But he himself has more than once shown, by a noble example, the benefits which science obtains by casting itself beyond the limits of fact, provided that care is taken at first not to give more than a simple hypothetical value to that which we may desire to bring forward. In the question which occupies our attention, we must embrace at one glance the whole animal kingdom since its commencement, in order to deduce the truth of facts which have been observed; only then these relations, for which science so ardently seeks, would appear in their proper light. On account of this impossibility, we must hope for some more enlightenment, chiefly from geology, and perhaps from experiments. "How many facts would be necessary," said Buffon, " in order to pronounce authoritatively, or even to conjecture? How many experiments are to be tried in order to discover these facts, to acknowledge them, or even to anticipate them by well-founded conjectures?'”

Two opinions on the origin of species deserve to be noticed, -those of Cuvier and Lamarck. This last held Buffon's opinions at the end of his career, and it ought to find in Etienne Geoffroy a defender even more powerful in our eyes than Isidore Geoffroy himself; and especially Darwin, to whom belongs the merit, however, of having propagated, in his popular work, the ideas of Lamarck.

Cuvier's theory seems to be still the dominant one ; it is surrounded by that scholastic prestige which is explained by the 
word classical; it is only fit for universities. Cuvier proclaimed the immutability of species, and wished that at every revolution of the globe (the word alone then made his fortune), a new fauna might come ready made from the hands of God, to animate the burning or icy lands of the old world. But Cuvier, in proclaiming organic immutability, excepted mankind. We must be allowed to doubt whether it was done with good faith. "Cuvier, full of good taste regarding political propriety," said a son of the republic, his former master, now his adversary,"Cuvier, filling his mind with wise mental reservations concerning the future of society, declared that it was not fitting that new discoveries, just dug from the heart of the earth, should attack and oppose with hostile malignity the venerated and ancient revelations of our holy books."* This remark, in which Etienne Geoffroy has concealed his anger and contempt under a guise of perfect urbanity, will remain to the end, we are convinced, as the judgment of posterity upon the naturalist statesman, and upon that which they call in France at the present day official science. Species was, then, a definite entity in Cuvier's opinion, and if he had been consistent, he would doubtless have become the promoter of the idea which has been taken up by Agassiz,- - that there were several centres of creation on the surface of our planet after the last flood; in each of these centres would appear a special fauna, and also one of the species constituting the genus homo.

These different species of men and these different fauna would since have continued to occupy the same geographical areas with merely some alteration. An absolute value is given to species in Cuvier's theory, as well as in that of Agassiz; it is unchangeable; it may disappear, but cannot be modified, so that "each of them," as Buffon said at the commencement of his career; when he held the same views, "remains always separated from the others by an interval which nature cannot overstep."†

*. E. Geoffroy, Comptes Rendus des séances de l’Académie des Sciences, vol. v, p. 193.

$\dagger$ See Isidore Geoffroy Saint-Hilaire, Histoire Naturelle Générale, vol. iii, p. 210. 
Such has been, for a long time, the theory of the origin of species which we have held, and which we maintained in the first edition of this book. In fact, the solution which we now offer differs considerably from that which we then gave. But there is evolution rather than contradiction in going from one to the other. The differences which separate mankind are not lessened, and have not diminished in value in our eyes : we merely explain these differences in another way. It cannot be called contradiction, or even inconsistency, to change one's manner of viewing things with the times; to regard things otherwise which, as we said before, have no absolute basis; or to change in five years one's opinion concerning the origin of the living beings on the surface of the globe.

In Buffon's last opinion* species was not that definite entity in which Cuvier believed, commencing at a given geological moment, in order to terminate at another. Buffon says, in his latest works, that the idea of species can only be seized upon by man at "this or that instant of his age," $\dagger$ and that it is merely the expression of the ambient medium. Let this remain as before, it will not change; but when the conditions of the medium become modified, species will change. We thus arrive at this definition :-

* We are almost tempted, in all kindness, to refer our author to the following remarks in the Reliques of Father Prout, p. 264. "I have been at some pains to acquire a comprehensive notion of the Count de Buffon's system, and, aided by an old Jesuit, I have succeeded in condensing the voluminous dissertation into a few lines, for the use of those who are dissatisfied with the Mosaic statement:-

1. In the beginning was the sun, from which a splinter was shot off by chance, and that fragment was our globe.

2. And the globe had for its nucleus melted glass, with an envelope of hot water.

3. And it began to twirl round, and became somewhat flattened at the poles.

4. Now, when the water grew cool, insects began to appear, and shell-fish.

5. And from the accumulation of shells, particularly oysters (see vol. i, p. 14, 4 to, 2 nd ed.), the earth was gradually formed, with ridges of mountains, on the principle of the Monte Testacio at the gate of Rome.

6. But the melted glass kept warm for a long time, and the arctic climate was as hot in those days as the tropics now are,-witness a frozen rhinoceros found in Siberia." Let the leaven work, although a mere joke to M. Pouchet's reality.-EDITOR.]

+ Histoire Naturelle, vol.ix, p. 127, 1761. Etienne Geoffroy (Comptes Rendus, vol. iii, p. 29) says the same thing "as regards the actual constitution of the globe; each race is a species sui generis, - a form or combination of its own in nature." 
Defrnition.- "Species is a collection or group of individuals characterised by a similarity of distinctive points, the transmission of which is accomplished naturally, regularly, and indefinitely, in a given order of things."*

It is, in more scientific terms, the definition by Lamarck, "a collection of similar individuals which generation perpetuates in the same state, so that the circumstances of their situation do not sufficiently alter so as to make their habits, their character, or their form vary." $\dagger$ Lamarck, to whom Isidore Geoffroy has rendered greater justice than any one else before or after him, $\ddagger$ admitted the unlimited variableness of species. He admitted that we all descend, just as we are, from an anatomical element, developed in a determinate sense, and that we may have been worms, insects, $\S$ birds, and mammals before becoming men, running through all the phases through which animal organisation has passed during our uterine life. We see that Lamarck approached frankly and resolutely the problem of the origin of humanity.

In taking but superficially certain exaggerations into which Lamarck fell, at a time less rich in facts than our own, it is not difficult to give a certain grotesque turn to his ideas, and to laugh at them as being unnatural; but we must not thus judge the work of a man's whole life, and we must appreciate Lamarck by the basis of his doctrine more than by the examples he has given us: "a profound philosopher," said Etienne Geoffroy, $\|$ " able in laying down principles, less able in the choice of his proofs."

We must judge Lamarck as Isidore Geoffroy has done in his Histoire Naturelle Générale, where we find a complete and im-

* The terms of this definition are almost entirely borrowed from Isidore Geoffroy. By ending it with these words, "in the present order of things," Isidore Geofiroy only defined the existing species, and took away, without any reason, the palæontologic species.

† Lamarck, Discours de l'An XI, p. 45.

\.ee Flourens, Examen du livre de M. Darwin sur l'Origine des Espèces, $18 \mathrm{mo}$, Paris, 1864. We are at least astonished to find the name of the Geoffroys mentioned but once in such a work (p. 45). M. Flourens charges Darwin with only quoting the partisans of his own opinions (p. 40).

$\S$ [See above, p. 84, note.-EDrTor.]

\|| Sur l'Influence du monde ambiant, 1831 (Mémoires de l'Académie des Sciences), vol. xii, p. 81 . 
partial chronological statement concerning the grave question of species.* "Circumstances have an influence upon form and organisation," such is the fundamental principle of Lamarck's doctrine; $\dagger$ he says the same elsewhere: $\ddagger$ "Circumstances determine positively what each body may be;" and he concludes, " among living bodies, nature only shows individuals who succeed one another. Species, amongst themselves, are only relative, and are only temporarily so." \$

If from these general considerations we enter in detail into Lamarck's theory, we find room for the objections with which the opponents of the system of variety are engrossed, with which they have made those weapons of ridicule which act so well on minds which are not forewarned, and who are ignorant of this master's whole system of ideas. The grandeur of Lamarck's views, the majestic simplicity of his theory, ought to be sufficient to shield him from such attacks. He saw at the beginning organic matter grouping itself under simple forms. These first outlines, altered by time and circumstances, have successively given birth to radiated creatures, to the inferior molluscs, the articulate animals, then the lowest fishes, then man.

Here is a mistake, in our opinion; if there exists (until we know more) an immense and impassable difference somewhere in the animal kingdom, it is between the vertebrate and the invertebrate animals. Whilst the first show an admirable unity of organic composition, the second do not seem to have any at all, so that they do not admit of serial or linear classification. Each of the groups which they form is united by some particularity to all the other groups, and naturalists have even been able to differ about what must be considered as the highest round in the animal ladder. The organism of the invertebrata possesses a flexibility and immense variety, which is almost a characteristic special to these beings in which the nervous system ceases to present the profound unity which we

* Vol. ii, second part, 1859.

† Philosophie Zoologique, vol. i, p. 221.

I Système des Connaissances Positives, p. 143, 1820.

$\S$ Discours de l'An XI, p. 45. He says, also, in another place (Philosophie Zoologique, vol. i, p. 66), "What we call species, has only a relative constancy in that state, and cannot be as ancient as nature itself." 
see in the vertebrata; whilst the entire group has only a negative characteristic, the v:ant of vertebrce, which is sufficient alone to show how unnatural it is. As for the rest, the vertebrate animal, even at the first moment of his embryo life, is absolutely irreducible to any invertebrate type whatsoever, contrary to Lamarck's opinion. A vertebrate is to an invertebrate as two first numbers are to one another; all the vertebrata, on the contrary, are one to another as a simple number raised to different powers; they can all be brought back to their origin, and both the most complicated and the most elevated of the series are only the most simple ones arrived at a state of considerable perfection.

A still weaker side of Lamarck's theory is certainly the decided influence which he attributes to the actions and habits of organised beings, so as to modify them by their own means. The pedantic caprice of his enemies has always hit on this point. "The habit of exercising an organ," he says, "makes it acquire developments and dimensions which insensibly change it, so that in time it becomes very different. On the contrary, the faulty continual exercise of an organ impoverishes it gradually, and ends by destroying it."* But it must not be thought that Lamarck gave an appreciable alteration to the organ,-an alteration sufficiently rapid to be noticed by ourselves. If some passages of his works make the reader think so, it is plain that they are only the wanderings of a great mind, always weak on the side of the ideas which he has created, and which he cherishes. Lamarck knew very well that an infinite time is the condition of unlimited variability. $\dagger$

Darwin is the direct successor of Lamarck, and, in our opinion, the success of his book both in England and France is an index of the progress which scientific ideas have made, since the days of Cuvier, in the path of liberty and independence. Darwin, like Lamarck, admits unlimited variety; he thinks that all animals must descend from four or five primitive types, and plants from about an equal number; he is almost

* Lamarck, Organisation des Corps Vivants, p. 53.

+ For nature "time has no limit, and consequently has it always at its disposal." Lamarck, Système des Animaux sans Vertèbres, p. 13, 1801. 
disposed to admit but one primordial type for all organic nature.*

Darwin, however, seems to us to have fallen into a grievous exaggeration, or error of interpretation, formerly laid to Lamarck's charge, while he is at the same time defending an excellent cause. Without speaking here of the relationship (forced, in our opinion) which Darwin makes out between wild and domestic animals (of which we have before spoken), the learned Englishman seems to have accorded too much to individual action in the production of specific modification. $\mathrm{He}$ sees a powerful activity, which he calls natural selection, where we can only see absolute passiveness. We will explain what we mean : in the midst of this vital concurrence, which he has in part so well described,-in the midst of this immense struggle, where all which has life on our planet is engaged in combat one against the other, or against all, on this eternal field of battle, where the victors become the victims, Darwin supposes that an animal brings into the world with him, by chance, some psychological modification, or some anatomical disposition, which is individually advantageous to him in the great struggle for life; after this he will have a chance of being among the victors, of uniting himself to another animal as happily endowed by birth by having also conquered; they will together leave a numerous posterity, and there is every chance that some of the descendants of such a couple may inherit either the same instinctive disposition or the same conformation; definitively, and by the repeated action of this natural proceeding, a new variety can be formed, and may either supplant the parent species or coexist with it. $\dagger$

Such is, in a few words, the theory of natural selection. In our ideas, there is here a false interpretation of facts; we do not believe in this chance of a native disposition, which thus transmits itself in order to become in time a specific charac-

* Darwin On the Origin of Species, p. 518, London, 1861. "I believe that animals have descended from at most only four or five progenitors, and plants from an equal or less number. Analogy would lead me one step farther, namely, to the belief that all animals and plants have descended from some one prototype."

+ Compare Darwin On the Origin of Species, p.96, 1861. 
teristic. We have shown, while speaking of hybridity, that a native individual disposition ought always to disappear by the mere fact of its being individual ; it quickly disappears through cross-breeding at the tenth generation, if not at the first, in the midst of a population which does not possess it. We fully admit, like Lamarck, that species are formed from one another by the appearance of organic modifications, more or less decided; but we do not leave anything to chance in this phenomenon, as Darwin does, and we can only see there the application of general laws.

It is not one or two animals, born with some special psychological or anatomical disposition, who are destined to generalise themselves by generation : it will be all the individuals of the same species in a certain radius, who will be born with a scarcely appreciable organic modification, resulting, as far as we can tell, in an action of the medium also nearly inappreciable by ourselves, but which long ago will have made itself felt by the parents. The new variety will be propagated quite naturally, since it is general, and can but increase with each generation as long as the modifying cause continues to act.

Etienne Geoffroy had been the worthy successor of Lamarck, with a larger and more philosophical mind. He never fell into his exaggerations, nor into the restrictive applications of the system, like Darwin. Let us see how Isidore Geoffroy* continues his father's theory: "Species is variable under the influence of the ambient medium; differences, more or less considerable according to the power of the modifying causes, may in time be produced, and the present beings may be the descendants of the former being." This doctrine is our own also.

As to the idea of limited variety, propounded by Isidore Geoffroy, we can only see in it an unfortunate restriction of his father's theory, - one of those errors into which even the most judicious minds are liable to fall. Limited! Does he mean that there is a point where these variations stop, and consequently a point where they have commenced? Does he mean

* Histoire Naturelle Générale, vol. ii, p. 421, 1859. 
that some neighbouring animal species are derived from a given prototype, similar to themselves, and without any antecedents in the organic world? This is to return to Cuvier! Limited! Does he mean that the modifications will not be considerable in the present state of things, on account of this present state being more or less modified? It comes to nothing directly we admit variety as a consequence of the medium. Étienne Geoffroy was led by this kind of idea, when, limiting his view to the short period of historical time, and thinking he had discovered that our present climates do not sensibly alter existing species,* he asked, "if there had not been on the earth revolutions and disturbances of so vast a character that their influence may not have been enormous; whilst in our days, changes may have been according to the power of their effects, that is to say, almost nothing:" And he explained everything by this convenient theory of geological floods.

Before going farther, let us consider what we ought to think about the disturbances of the terrestrial globe thus invoked by Etienne Geoffroy. Now, to our mind, we have no authentic proof that the past of our planet has really been marked by such frightful revolutions, and geology does not make the tradition as clear as some have desired. We think, although this is not the place to prove it, that if the changes which have happened to the surface of the globe have been considerable, they ought to be proportionally weak, resulting less from sudden and powerful efforts than from those small and continuous actions $\dagger$ in which nature puts forth its most formidable energies, but the progress of which is not to be measured by the memory of man. In general, our mind seizes but badly the notion of duration beyond certain limits. It is not the same with the notion of force. Hence, the belief in floods. In the presence of gigantic effects, the mind, in the appreciation of the movers of this effect, has done what we have done every

* "The observation of species in a state of nature, by revealing to us a multitude of modifications more or less important, cannot show us any serious deviation from the types formed or preserved by the influence of the existing state of things." 'Isidore Geoffroy, Vie d'Etienne Geoffroy, p. 349.

+ See Leibnitz, Protogé, transl. by Bertrand de Saint-Germain, Introduction, p. 61 . 
day in mechanics. "It has changed mind into force." It is certain that weak but continuous forces (everywhere, however, the most powerful) have been able to play a grander part in the history of our globe, than these disturbances which we are in the habit of seeing everywhere.

We consider that there ought to be an entire revolution in the system of geological research; it ought to commence at ancient times, and come down to the present day, not vice versâ; we ought, in fact, to substitute synthetic for analytical geology. After having carefully noticed contemporaneous phenomena, we should doubtless be in time able to read simply the trace of a feeble revolution in the geological past, accomplished under the government of the same forces which are daily preparing new lands, new elevations, new depressions, and a new organic world on the surface of the globe, for the future. If it is probable that the atmosphere has changed within certain limits, if the nature of the waters has also been altered,-at least all these geological phenomena, these abysses, chains of mountains, and submerged continents, can only be the result of the forces now at work under our own eyes,-the comparison of animals which formerly existed with those which exist at the present day, shows, as we shall see farther on, that the conditions of life have not sensibly changed on the surface of the globe since the formation of the rocks subjacent to the metamorphous rocks.

We deny that the earth is actually passing through a period of repose, and we do not believe that it has ever formerly been more disturbed. Since the age of the first vestiges of the organic life, which we find in the most ancient rocks, we think that our planet has not ceased to move in a calm and continuous march of existence; we think, in fact, that geological phenomena of all sorts, which we hear of now-a-days, are the exact history of the past, during which some volcanic phenomena have also taken place, but in an entirely sporadic manner. "The day is, perhaps, not very distant," said M. Lartet, at the Institute,* in 1858, "when it will be proposed to strike

* Comptes rendus des séances de l'Académie, February 22, 1858. 
out the word 'flood' from the vocabulary of positive geology." This day approaches still nearer.*

Before mooting, in our turn, a theory about the vertebrate animal kingdom (the only one which ought to occupy our attention) on the surface of the globe, we simply ask, what is meant by Etienne Geoffroy by the words some considerable time? This is a difficulty, we own, and we have just said so. We wish that the thirty thousand years, $\uparrow$ the maximum time which we give to the farthest origin of man, should be considered as being the age which separates us from the first organic matter cast into the bosom of the waters, in the same proportion as the radius of the earth is to the distance which separates our sun from the most distant star of the most distant nebulous

* We shall be thanked for publishing here the following extract from a letter addressed to us by Isidore Geoffroy Saint-Hilaire, the 3rd of June, 1860 , and which relates to all these questions. "I said, two or three years ago, as I have learnt from M. Lartet (who remembered the expression which I had myself forgotten), that the present movement of science tends to substitute in geology the idea of the evolution of the globe for that of revolutions. M. Lurtet has taken up this view, and adheres to it. It is of great importance to me, as regards my works on species, in which we must in this case substitute the notion of evolution for that of revolution; revolutions are here pretended creations, abruptly successive. It is time to have done with these views, which, instead of taking creation as having been once concluded, make at every instant the Deus ex machind intervene."

$+["$ In the neighbourhood of Mount Fitna, or on the sides of that extensive mountain, there are beds of lava covered over with a considerable thickness of earth; and at least another, again, which though known from ancient monuments and historical records to have issued from the volcano at least two thousand years ago, is still almost entirely destitute of soil and vegetation; in one place a pit has been cut through seven different strata of lava; and these have been found separated from each other by almost as many thick beds of rich earth. Now, from the fact that a stratum of lava, two thousand years old, is yet scantily covered with earth, it has been inferred by the ingenious Canon Recupero, who has laboured thirty years on the natural history of Mount Etna, that the lowest of these strata which have been found divided by so many beds of earth, must have been emitted from the volcanic crater at least fourteen thousand years ago, and consequently, that the age of the earth, whatever it may exceed this term of years, cannot possibly be less."-Brydone's Tour through Sicily and Malta (1770). Plato, in his Critias, mentions the island Atalantis as having been buried in the ocean nine thousand years before his own time. In the Universal History, vol. i, (preface,) we are told that the astronomical records of the ancient Chaldeans carry back the origin of society to the remote period of four hundred and seventy-three thousand years. Among comparatively well-known authorities, there is a good deal of difference in the time of the supposed formation of the world. The Hebrew bible makes the creation 3,944 years before the Christian era. The Samaritan bible, 4,305 years; the Septuagint, 5,270 years; Usher, 4,004 years; Josephus, 4,658 years; M. Pezron, 5,872 years. In all these differences, however, there is nothing so striking as in the theories we mention above, of Recupero, the Chaldeans, etc.-EDITor.] 
system which the best telescope can observe. The extent alone of the heavens can give us an idea of the extent of the past.

This being granted, let us see how we can represent the history of organic development upon the earth in a few words, without hiding from ourselves the immense obscurity which covers all origins. We are here expressing merely a hypothesis. It will suffice us to see if this hypothesis will agree in a satisfactory manner with the facts noticed at the present day, on the surface and in the interior of the globe.

At the origin of the vertebrate world, since we are only examining this, it seems rational to admit a primordial commencement, which nothing prevents us from considering as a new and special combination of organic matter, derived from the invertebrate world, which we may believe to have formerly existed. In the heart of this embryo will have appeared, by spontaneous generation, the first organism connected with the vertebrate type. This was, doubtless, a simple anatomical element, like that which histologists see every day formed in certain granular liquids.

We do not imagine that the origin of life can be otherwise represented; for to admit, as Isidore Geoffroy has done in certain passages of his works, that the will of a God peopled the earth suddenly with perfect beings, fit for producing other being's like themselves, would be to admit a miracle, and science teaches us at the present day what to think of all divine interventions, either past or present.*

We defy anyone to get out of this alternative,-either that there was an instantaneous and miraculous creation of a certain number of perfect animals ; $\dagger$ or that there was a succes-

* [Our author is quite right. Science does teach us what to think of divine power in its outward manifestations. The more we understand nature, the more ready will earnest-minded men be to praise and give glory to the God who made it, who created man and beast with such marvellous and exquisite regularity, and who continues to govern the world and all that is upon it. Perhaps M. Pouchet thinks he himself could have made a better one. It is a pity that a clever mind is so warped by that science which ought to make him more satisfied than ever that God is the creator of the world; and that spontaneous generation, and the never-clearly explained origin of the first matter, about which even M. Pouchet cannot tell us, with all his scepticism, ought to go to pave the "pathway of good intentions." EDITOR.]

+ [Why not?-EDITor. $]$ 
sive evolution, which is Lamarck's idea, modified by the sense of the new knowledge which we have at the present day, arising, on the one hand, from geology, and on the other, from philosophical anatomy.

Let us return to this primordial anatomical element which we may call individual-element. It virtually represents a vertebrate animal just as the ovum detached from the ovary of the female represents a man, who is only waiting for favourable circumstances in order to develope himself. This individual-element, according to our hypothesis, is at first simply reproduced; then, after some considerable time, its descendants, will, little by little, in their own sphere of activity, give birth to other elements in juxtaposition to themselves, in this manner perfecting it and identifying it more and more with the vertebrate type which it offers for our consideration. After some considerable time vertebrates of as simple an organism as mixinæ and lampreys will have thus appeared. Then, again, after another considerable lapse of time-millions of centuries, rather than thousands-these animals with elementary vertebra will have successively produced, by transformation, all the vertebrata which stock the globe at the present day.

We must here make an important remark. We have inferred by all which precedes this, that the vertebrata of the present day and the fossil vertebrata all descend from the same individual-element prototype, whose existence we have admitted. In one word, we think that all the vertebrata, both present and past, have the same genealogy, and are all relations. That may doubtless be the case; but nothing will make us admit that there once existed on our planet conditions fit for the birth of this individual-element prototype, and that these circumstances have never since been represented; so that the most simple vertebrata of our time may very well descend from a less ancient spontaneous genesis than the mammalia and man himself. Nothing hinders such a supposition. It does not cost us any more to admit that one day or other a simple organic element is formed, endowed with a life of its own, and, even more, with a latent life, which it can, by means of time 
and circumstances, diffuse around it; it does not cost us more to admit this than to admit that similar elements have arisen at different periods of time. This last supposition may even, be regarded as so much more probable, that we must renounce entirely, in order to explain specific transformations, the influence of the geological revolutions of which Etienne Geoffroy took so much account. We have seen higher up that these were far from being proved; we can add, in support of our assertion, a fact which we think has not been sufficiently remarked. If these revolutions ever existed, we have a strong proof that they have only very slightly altered the conditions of life on the surface of the globe, at least since the ancient periods during which the first alluvium was deposited; if we dredge some yards deep in the ocean, the drag brings up terebratulæ and encrini; that is to say, animals identical with those which we find in the most ancient alluvia. Is it not remarkable that the lowest placed fossil in the stratigraphic ladder of the beds of the terrestrial surface, the most ancient fossil which we know, is precisely this same terebratula, which still lives in our seas? What must we hence conclude? That there once existed on the globe, at least to a certain extent, conditions of aquatic life sensibly identical with those which exist at the present day.

Whether all the species of vertebrata descend from one original spontaneous beginning, or from many successive ones, signifies very little, since, in the second case, the primordial individual-elements which have thus appeared at various times, would always show a great analogy to one another.

Now, after all that we have said, this is how we may, in our opinion, represent by a graphic figure the whole of the vertebrate kingdom, $*$ in the present and in the past. Let us image a conical figure: the individual-element of which we have spoken will occupy its summit. From this point a number of straight lines, few at first, will start, branching off and

* Some may be astonished at our applying the word kingdom to the vertebrata. We do so because, in truth, the distance which separates them from other animals seems to us almost as great, and even more decided, than that which separates the invertebrata from plants. 
always multiplying themselves with more or less regularity, but so as to form an immense cone.*

Each of these straight lines would represent a specific modification, accomplished after a certain number of generations under the combined influence of the ambient medium and of some considerable time: in other terms, each ramification would represent a species having once existed or now existing on our planet. The length of each line would measure the time which the species in question has existed. These lines would never converge, because we do not believe in the creation of permanent species by means of hybridity.

Now the mind must admit here all possible combinations; certain species have disappeared without producing any others after them :-others exist actually without our having any idea of one of the intermediary species which have been allied to primitive species; - others have subsisted slightly or not at all altered from the remotest antiquity up to our own days, thus becoming through contemporaneous time the transformed descendants of fossil species, of which they were also formerly the contemporaries; it is even not impossible but that certain species succeeding one another may have presented a retrograde evolution, so that we must not always conclude that because one animal is only inferior to another, it has therefore preceded it:- without going so far as all this, the evolution of certain species may have presented a long time of cessation whilst all others were progressing around them, so that they appear to have retrograded. This is what has made M. Michelet† say, "Nature has not progressed with a continuous flow, but with retrograde movements, and stoppages, which allow her to harmonise everything." These times of repose in a specific evolution, as well as the hypothesis of successive geneses which are already admitted, explain how the stratified beds of the earth's surface, in showing from low to high what we may call more perfect organic means, unveil at the same

* The diagram which Darwin has placed in his book On the Origin of Species, is only a fraction and piece of detail of the general figure which we are endeavouring to place before the mind of the reader.

† L'Insecte, p. 128, 1858. 
time to our eyes here and there a certain number of species, inferior in organisation to those in the most ancient rocks.

As to explaining how a part of the ancient species has been able to modify itself whilst another has remained stationary, we must admit that all these influences of medium have always been exclusively local, so that all the coexisting vertebrata have never been able to submit at once to its influence. We must understand by medium, the whole of the circumstances, past or present, which are able to influence organism mediately or immediately in any manner whatsoever. The ancestors of an animal, as well as the sun which warms it, and the parasites which devour it, make up a part of this medium.

But if it is easy to explain variety by the medium, it is a difficulty against which the mind struggles. How can we explain ascending and progressive variety? must we believe in some finality, an end settled beforehand? We do not think so. Finality is a sort of divine prevision, and the world as regards this hypothesis is still in tutelage; we would rather believe in. a creating intelligence. A simple example will make our meaning understood. In the vegetable world this strikes us forcibly:-the most simply formed plants are precisely those which approach most nearly to animals by reason of their physiological manifestations.* The plants which they call superior, by placing them in an organographic point of view, are in reality inferior, so that these plants are simple in reference to the dicotyledons which have necessarily succeeded them, and there has been in reality a retrograde march of life, instead of the ascending march of the animal kingdom. Must we seek for the reason of this difference in the presence of a nervous system? We think so. We then would admit that organism would tend to modify itself by an inconscient act of the will, analogous to those which rule most physiological actions; this would be something like the possible increase or growth of the head by reason of the influence of civilisation of which we have before spoken. $\dagger$ And whilst all the specific

* Predominance of the immediate azotic principles, respiration comparable to that of animals, voluntary movements, indivisibility of organism, etc.

+ [See above, pp. 46, 47.-EDitor.] 
varieties would result among plants from the influence of the physical medium, we must add to the notion of this medium, as regards animals, the nervous activity of the ancestors.

By the side of this creating influence we must recognise in the medium a parallel destructive influence. Now, we can appreciate this every day. The present tells us about the past; we cannot doubt but that species formerly disappeared exactly as we see them still disappear under our eyes by the manifestation of some new condition of the medium; these may be sudden; volcanic phenomena, floods, extreme variations of temperature, diseases, famines, enemies-all these hypotheses are possible, and all equally reasonable: the dodo has disappeared some years ago, having been destroyed by the hand of man; they say that the apterix will soon disappear in the same way, devoured by cats. But actions only moderately destructive were doubtless otherwise very important, and we find here all the phenomena which have been so well described, and so well explained by Darwin* under the name of vital competition. By this we see, even since the most ancient historic periods, that certain savage animals, like the lion, $†$ crocodile, $\ddagger$ and hippopotamus, $\|$ retire before mankind; that the black rat is disappearing in Europe to give place to the field mouse, and that a race of savages disappears when their country begins to be inhabited by a more civilised race, even when the victors in this organic, as well as political, struggle, are not able to reproach themselves with any cruelty.

Now, let us apply to man the theory of the origin of species which we wish to be dominant, for there is no reason to think that man forms any exception to the common rule. Before all

* See On the Origin of Species, chap. iii.

+ Lions hindered the army of Xerxes in Macedonia. They abounded in the province of Africa in the time of the Roman Emperors. At the present time, however, Gérard was obliged to watch for three hundred nights in order to kill only thirty or forty.

† The crocodile, which used to swarm on the Delta, is now only found in Upper Egypt.

II The hippopotamus, since the Roman occupation, has successively retired from the mouth of the Nile to the fourth cataract. Some years ago, there existed one, and one only, at the Island of Argo, on this side of New Dongolah. Some hunters killed it, and since then, they have only been found at the Berber level. 
things, we must remember that human races cannot lend themselves to any classification in natural series. It is also as impossible for the naturalist to point out a race at the present day from which all the others are derived, either parallelly or successively, as for the historian to discover in the past any trace of a homogeneous humanity. If even such an uniformity had ever existed, how would the remembrance of it have been kept, for it is evident that this primitive form, constituting at the beginning all the human genus, would be the same inferior form, such as the Negro or the Bosjesman, for instance, nature rising in general from inferiority to perfection. This was for a long time Prichard's idea, and certain monogenists think the same at the present day. This hypothesis, entering at its basis into the doctrine of evolution, has nothing in itself which is startling; we can only say one thing against it, and that is in its admitting as proved that filiation which would connect one with the other all the groups composing in our times the genus homo. For our part, we wish simply to extend the same manner of viewing the matter, to generalise it, and to place it in relation with this immense unknown which is behind us, and of which monogenists do not take enough notice. We maintain that there has existed in the night of time a certain species, less perfect than the most imperfect man, remounting by a certain number of intermediary species, of whose nature it is impossible for us at present to form any idea, - to this primordial vertebrate animal which we admit. This species, a rough outline of what man now is, gave birth, after a considerable time, to many other species, whose parallel and unequal evolution, following what we have said concerning animals, has at the present day as contemporaneous (but not the last) illustration, the different species of men designated by the name of races. So that all humanity would be in relationship, if the expression be allowed us, not in the serial sense, as monogenists take it, but in the collateral sense, and at a degree which we cannot determine; the prognathous races probably less deviated from the former type, the others more separated from this type, and more perfect. 
It may be seen, and we are bound to make the remark, that we no more pretend to make man a descendant of the ape, than a white man a descendant of a Negro; but it is not impossible, in our opinion, that species of men, as well as the great apes whose relationship hurts our vanity so much, may remount infinitely far in the past to an unknown single species, whose descendants, submitted to multiplied influences, might be modified in different ways by reason of these different influences.

We admit, then, that species is an instant of a constant evolution; that it does not exist by itself; and that it is only an - appreciation of our senses, localised by time. In our opinion, if species is fixed, it is fixed after the manner of the sun. That is to say, that we cannot perceive any movement in it beyond the merest trifle.

It requires thousands of years to discover either solar displacement or specific alteration. This is what makes the determination of species so difficult; some of which may be considered as in progress of formation in reference to others. The difficulty is the same with mankind as it is with animals. We would not dare to contradict, for instance, the opinions of those who see in the Hindú, German, and Celtic population three species in course of formation, all three being probably derived from a species anterior to that which history endeavours at the present day to name; that Aryan race of which such a noble picture is made, and which we believe to be primitive because it is in the horizon of history, just as the ancients saw in the ocean the limits of the world. In a short time, perhaps, some discovery in a poor Asiatic field will take away from the Aryas the characteristic nobility and intelligence which we give to them with so much satisfaction. It belongs to human palæontology alone to enlighten us upon the origin of the present human types; it alone can lead us in a sure path towards the great problem of their origin.

But both geology, and palæontology which depends on it, have the singular destiny of showing at one and the same time both great certainties and insoluble doubts. The stratification of rocks, for example, gives us very clearly the notion of the suc- 
cession of these rocks with regard to one another. But it leaves us in absolute ignorance of all which has passed between the deposit of one stratum and the deposit of that which we meet with above it; in this unknown time all may take place, ten series of rocks may have been placed upon it, and then have been so well mingled together that we cannot discover their individual trace. Who will tell us about the continents engulphed by the sea; has it not already ground up under its waves those memorials of ancient days, which would be so useful to us as a means of reconstructing the history of man? Geology is a gigantic inscription lacerated for ever : each age will decipher some fragment, but we shall never be able to read it in its perfect state.

Besides its great advantages, palæontological inquiry has its great inconveniences. Its advantages are the studying of animal forms which are fixed for ever, and not seeing the field of such studies continually increasing on our view. The limit of its inquiries is the origin of the alluvium; all the facts which we are thereby called upon to study are within this boundary. Palæontology alone, among the sciences of the present day, knows the extent of its domain.

But palæontology, proceeding step by step, by blows of the pickaxe in an otherwise inaccessible mass, is composed of two orders of facts, which must be distinguished one from the other, resting either on affirmative evidence (the existence of organic remains in a rock) or on negative evidence (the absence of organic remains in a rock). Human palæontology itself has its own inconveniences. A bone or a skull of a man are things which are well known; they have not that strange appearance in the eyes of the crowd which makes them take ammonites for petrified serpents, hamites* for leeches, radiated animals for stars; when we dig up some singular bone, some carapace of a lizard, a fish, or of some unknown animal, we pick it up, and take great care of it. But if it is a man's head, it is generally replaced religiously in the earth, and these remains are for ever lost to the scientific world.

\footnotetext{
* [Hamites, a genus of extinct Cephalopods, found in the greensand formation in England.-EDrTor.]
} 
There result from all this two sorts of ideas in palæontology, the one positive, the other negative : it is true, however, that the latter diminish continually the profit we obtain from the former, and it is important to remember that this negative evidence is the only basis upon which rests the hypothesis that man is so new to our globe as some imagine. Every moment we may expect to see the interior of the earth prove the contrary. Instead of discoveries following one another, and being linked together as in other sciences, forming a whole which hangs together by itself, palæontology goes on from hand to mouth, as it were, at the caprice of whatever may happen, without knowing the wonder which is about to be revealed, perhaps at a few steps from a path which millions of men have passed by.

It is very true that the human bones which have hitherto been found in the ground in caverns seem to proceed from a form but slightly different from our own; but all this is very recent, relatively to this considerable time of which we have before spoken. Who can say but that we may find very soon a skull which must be classed, whether one will or not, between the anthropomorphous apes and man?

Etienne Geoffroy, led by the logical nature of his ideas, naturally admitted this intermediary form, anterior to our own; but seeing the mammalia of the last geological ages generally larger than those which are contemporary with ourselves, he concluded besides that our immediate ancestors were giants, and that we have degenerated, like the descendants of the bears and hyenas found in caverns.* Nothing has ap-

* Comptes Rendus, vol. iv, p. 58. Perhaps the only logical deduction which we can really draw from the greater size of these animals, is the greater extent of the continents which they inhabited. The belief in the gigantic dimensions of the fossil fauna and flora, is also a remains of the marvels which the first inquirers into science involuntarily reported. In examining matters nearer and more impartially, we see that certain zoological groups have been, in fact, formerly represented by larger species than at the present day; but until we arrive at some new discovery, we have the right to think that the other groups of animals, on the contrary, have a class of larger representatives than in former times ; like the quadrumana, the cetacea, insects, cephalopods, acephalous mollusks, etc. But this pretended decay is especially false as regards plants; if we find in the ground some large ferns, or enormous grasses, we must subtract a good deal from those so-called antediluvian forests, which many have not hesitated to bring forward in support 
peared in order to justify this hypothesis, and everything seems to show that since that epoch the height of the genus homo has not much altered, whilst the size of the different genera of ferines, ruminants, and pachyderms has positively varied.

Recapitulation. Since we have found that man is comparable in all points to animals, we ought to seek for him and for them a common origin, and the difficulty of admitting an initial miracle has led us to the idea of evolution. If in the science of observation it is permitted to refer to general ideas, assuredly it is so in this case; philosophy commences where science ends, and it belongs to it to give us an explanation of the matter ; but we must wait for the future for a true positive solution of the problem, perhaps from advanced geology, perhaps from experiments. The genius of man has no bounds, who can say to what it may reach? who knows whether, like a new Prometheus,* a creator in his turn, he may not one day breathe life into some new species, which will suddenly appear from his laboratories?

of their ideas. All the fossil plants that we know are, without exception, extremely wretched in comparison with the gigantic conifers and dicotyledons in the forests of the old and new world.

* [If this new handiwork of man, so charmingly arranged by our author, is not more successful than Pandora, as made by Vulcan, we fear the world will not gain much by it. In the olden times, the man who propounded such curious ideas would probably have had a punishment awarded him, something similar to that suffered by Prometheus. Does M. Pouchet, in quoting this personage, entirely forget the rest of the tale, and the consequences of his rashness? We are really sorry, however, to see science perverted to a pet idea, if we may use the expression, and twisted by means of "bad anatomy and worse theology," as a friend of ours calls it, for the sake of proving facts quite impossible to be solved. M. Pouchet gives us, in spontaneous generation, a first germ with which to start a primordial anatomical element, as he calls it. He starts with this, and argues-in what manner we leave it to our readers to determine-that, from this germ there have, in time, sprung all the animals on the surface of the globe. But he does not tell us how this first germ itself arose. That is put entirely on one side, and taken for granted. We cannot take it for granted however; and until we have it satisfactorily proved that he is right in any part of his idea, we shall go on thinking and believing as we have done before.-EDITOR.] 


\section{CHAP'TER IX.}

\section{SYSTEM.}

ALL science leads necessarily to a system; and system signifies here, not the proceeds of observation or a route followed by analysis or synthesis in order to arrive at the knowledge of the truth. System here means, a mode of classifying beings or observed facts, a mode essentially in connection with the science which treats of these beings or of these facts, and often applicable to itself alone.

A perfect system can only be really established à posteriori, after the knowledge has been acquired of all the phenomena which are to be classed. This is absolute. In practice, a system can only be observed $\grave{a}$ priori, by reference to a certain number of facts which it is destined afterwards to embrace; it is only true that the more facts we acquire, the more chance has a system of being exact, without our ever having the right of proclaiming it to be absolutely good ; it may be satisfactory, and remain so for a long time, but one fine day a new fact may prove it to be false. "I am of opinion," said Etienne Geoffroy, "that a perfect system cannot exist; it is a sort of philosopher's stone, impossible to be discovered."*

A science being given, it does not at all follow that there already exists a proper method for classifying in a natural series the phenomena which manifest themselves to us in this branch of human knowledge. If we have not yet succeeded in discovering a true anthropological system, if Camper, Prichard, and Morton have been foiled, it is because the science of mankind is still too new.

Even in making an abstract of the difficulties always to be

* See Isidore Geoffroy Saint-Hilaire, Vie d'E. Geoffroy Saint-Hilaire, p. 287. 
found in determining every animal species, difficulties which are derived from the way in which we understand its evolution,* must we be astonished that the human race is not yet divided into distinct groups, when animals, much more easy to class on account of their lesser degree of intellectual and social activity, are not yet classed in a satisfactory manner,* when the Geoffroys, Cuvier, and De Blainville have failed in something or other, since this question seems still worthy of examination by the greatest minds of Europe with which the natural sciences are honoured at the present day? The natural history of man is of to-day, and the difficulties are great, because by virtue of his intellect man possesses resistance and special affinity. Living by nations, he lives a double life ; his own, and that of the nation-which is a separate thing-into which a neighbouring race or species can enter wholly, adopting the same customs, the same dress, and the same language. There are difficulties which we meet with in anthropology, and which we only meet with there. A species has been known to disappear, for instance, and has left its name to some group entirely different from it, for if the Ethnic name has served at the origin to name the inhabited country, the geographical name has reacted in its turn, and has imposed itself on all the people who have successively occupied the same area. Other difficulties will arise from regions inhabited by distinct species, if these limits are not marked by some physical barrier almost impossible to be passed.

Thus we are far, even at the present day, from agreeing about the bases of a good anthropological classification. Many methods have been tried, but none have as yet succeeded. Some have adopted geographical division. Oțers, the colour of the skin. Others, the state of the hair. Others (the most numerous class), have stopped at the shape of the head. The skull has chiefly exercised the sagacity of anatomists and anthropologists, and we can say fairly that, there is no combination to which it has not been submitted in order to arrive

* See above, chap. viii.

† Compare Owen, On the Characters, Principles of Division, and Primary Groups of the Class Mammalia (Brit. Assoc. for the Advancement of Science, 1857.) 
at the distribution of mankind into natural groups. We must remark that all these cranioscopic classifications rest involuntarily upon this datum, that the different kinds of men are unequally endowed with intellect. Starting, then, from this principle, that the volume of the brain is in ratio to intelligence, or that intellect is in ratio to the volume of the brain, people tried to find a simple, rather than an easy, method of taking account of such an irregular solid: and Camper opened the way with his famous angle.

This system was soon followed by others who are less celebrated, having come after him. We may quote, among others, the interior angle of Walther, described by two lines, the one going from the occipital protuberance to the crista galli process, the other from the frontal prominence to the root of the nose. There is also the external angle of Mulders, described by the facial line of Camper, and another line going from the base of the process to the root of the nose. And, lastly, that of Daubenton, described by a line going from the inferior margin of the orbit to the posterior region of the occipital orifice, and by another following the direction of the plane of the same.* All these systems are worth as much as Camper's. All, including Camper's, are false and worthless, from the mere fact that they pretend to measure a solid by the inclination of two of its boundary-planes one upon the other. After these methods of measurement, and superior to all of them, comes the norma verticalis of Blumenbach; then the measurements of Cuvier, Owen, etc. Here we gain a step; we endeavour to measure a solid by its outline, or by the area of a systematic division or section. Already had Camper, better gifted than his angle would inform us, endeavoured to compare the different diameters of the profile of the skull, as seen in front.* As to Cuvier's division, it is a very happy modification of a former proposed measurement, the incisive-occipital line of Doornick. It is obtained by lowering a vertical line to the plane of the external auditory orifice, and by leading another

* See, for the explanation and discussion of these different systems, Crull, Dissertatio de Cranio, 1810.

+ Compare Crull, Dissertatio de Cranio, p. 28, 1810. 
line from the incisors to the extreme protuberance of the occipital region. The relation of the two determinated divisions in this line by its intersection with the first, will give the statistics of comparison.*

Progress has been immense, and yet our systems remain very unsatisfactory; the skull seems to escape every method of measurement. Some time ago a meeting of craniologists took place at Gottingen, and yet the learned assembly was obliged to separate without settling anything. $\dagger$ It seems that the old saying of Bernard Palissy about measuring some peculiar skull, will remain true in spite of all our efforts: "I have never known how to obtain a correct measurement." $\ddagger$ Another method is that of Morton, to which he has attached his name by the multiplicity of facts which he has drawn from it, by the justice of the views which he has expressed, after having used it thousands of times; we speak of the direct measurement of the interior capacity of the skull. It is for ever to be regretted that Morton finished his laborious career without having been able to publish the ultimate results of his long researches; but this method (which M. Broca has actively applied), is, however, not quite perfect. If there was merely a difference among the different races in the amount of

* Compare Crull, Dissertatio de Cranio, p. 52.

+ Busk and Quekett (Medical Times and Gazette).

I One always endeavours to find some former indication or presentiment, although even confused and full of obscurity, beyond the origin of positive science; it is curious to find in the works of the potter physician a sort of germ which, when developed, may have given birth to cranioscopy, - a sort of foresight of the importance which the measurement of the skull would one day acquire. It is in the Recepte Véritable: one of two speakers relates a dream in which he saw the different instruments used in geometry dispute about precedence : he answers them, that man is above them all; they exclaim, that man cannot even use one of them in order to measure any part of his body. [We think it best to give the original here.-EDITo's.] "Quoy voyant, il me print envie de mesurer la teste d'un homme, pour scauoir directement ses mesures, et me sembla que la sauterelle, la reigle, et le compas me seroient fort propres pour ceste affaire, mais quoy qu'il en soit, ie $n^{\prime} y$ sceu iamais trouver une mesure asseurée." Bernard Palissy, Euvres, p. 93, 12mo, Paris, 1844. Blumenbach says somewhere, "The habit and constant use of my collection of skulls makes me understand every day the impossibility of subjecting a variety of skulls to the rule of any possible angle, the head being susceptible of so many forms, and the parts which compose it being of so many different proportions and directions." See Morel, Traité des Dégénérescences dans l'espèce humaine, p. 68. M. Aitken Meigs, at the present day, shows no less than twenty-nine different measurements of the skull which must be obtained if we wish to have anything like a satisfactory idea of the same. 
intellect shown in their works, this measurement would be sufficient to establish a division; but there is more than that; all races have different aptitudes, and here is to be found the fault of Morton's system, which only takes the whole, which makes no distinction between very different skulls if they have the same volume, like those of the Esquimaux, for instance, and those of Americans. The subject of measurement differs, like intellect, otherwise than merely in dimension, and that which craniology wants is the definition of all these special tendencies of the intellect by as many tangible varieties as possible.*

Craniology is not anthropology ; it assists it materially, but the partial results which it obtains have not necessarily the same value in the more general point of view of anthropology. Every classification, based on the form of the skull, will be necessarily an artificial classification, because it will only rest upon one sole order of phenomena. Besides, this study presents great difficulties from the individual differences which the various heads show, in which the qualities belonging to the individual have been so far able to hide the general characters of the race, that these often remain unrecognisable. Divisions have also increased in proportion as craniological collections have come richer in specimens. Morton only reckoned eleven human races, but he believed under the truth. We may very well have a poor idea of the value of this classification by studying the materials which were used by the philosopher of Philadelphia. Besides the American race, Morton had only a very few skulls at his disposal. The Philadelphian collection, which has been much increased since his death, contained, only a few years ago, 1035 skulls, 38 of them pathological; there remain therefore but 997 . Out of this number the American race figures in 502, or more than one-half. There remains, therefore 495,154 of which came from the valley of the Nile; so that merely 350 skulls represent the whole of Europe, Asia, the Oceanic countries, and Africa (excepting Egypt). This is not much for the purpose of classing a population likely to be raised to five hundred millions of inhabitants. $\dagger$

* See above, chap. iv.

+ See Indigenous Races of the Earth, p. 320. 
It remains for us to study and determine the intrinsic value of each of these heads. The authentic production of a skull is not always easy to be established when it comes from the other side of the world, obtained by travellers who have not made a special study of anthropology; it is even less so when a skull is dug up in a burial ground, where there may be a certain promiscuousness very apt to hinder our inquiries. Errors of this kind steal into science only too often, and we have for a long time in particular objected to the name of Gallic mummy, which has been given to a body in a collection at Paris, the history of which does not at all justify this denomination, since we simply believe that when it was first dug up it was only referred back to the thirteenth century !*

Craniology was anthropology itself, whilst this science was being cultivated merely by learned men in their studies. If a skull does not always bear about it the stamp of the race to which it belongs, we must nevertheless own that it is the best representative of the dead individual. Craniology obtains all its weight and powers from the study of ancient races and extinct peoples. There it ought to intervene with an unequalled importance, for want of better points of reference. By its means anthropology can search in the past, clearing up those questions which history is incapable of explaining. In this manner Morton has been able to prove better than by any historical document that Ancient Egypt was inhabited by very mixed races, and composed of the most different elements, exactly as in our own days. But there remained a problem even more interesting: that of knowing if the different races who then inhabited the banks of the Nile were as much divided into various occupations as at the present day: the Albanians are all soldiers, the Copts all scribes and officials, the Fellahs all labourers, etc. Doubtless it would be possible, if not easy, to arrive at the solution of this new problem by collecting skulls and mummies with more care than has hitherto been

\footnotetext{
* See Strope, Description d'une Momie très-ancienne (Recueil Périod. d'Observ. de Médecine, vol. iv, p. 290, Jan. 1756). One may see in reading the account of a very able and judicious narrator how much ancient scientific observations alter with the times, when no care is taken to refer to the original sources.
} 
done, and, above all, by assisting the researches of the Egyptiologists, who can read upon the coffin that such and such a body is that of a workman, a priest, or a king. We may thus be able to ascertain if the kings of such or such a dynasty were black or yellow; if the dominant population of such or such a nome had the Coptic, Berberine, or Fellah type. Here we have a large field for study, which has been almost entirely neglected by the American school of anthropology, precisely because Morton found himself without information about the production and true age of the immense materials which he had at his disposal.

But we must not be forgetful : the classification of skulls by their shape, of hairs by their colour, or skins by their hue, is not the classification of races of mankind. We only perceive here one order of phenomena. A classification established upon such bases has its point of departure only in the mind of him who conceived it, and not in the nature of things.

We shall only have a natural and rational classification by comparing entire individuals one with the other.* To this we must come ; we must study at one and the same time the height, the skin with its dependencies, and, above all, the character of the countenance, the attitude, the facies, and the habitus of different races, which Caldwell called " the variety discoverable in the complexion and feature, the figure and stature of the human race; $\dagger$ " this something is explained in one word, which we call type, about which we are never mistaken, and which makes us say, "This is a man from the south, that is a man from the north; this is a Mongolian, that an Indian.” $\ddagger \mathrm{By}$ this means alone we can form natural groups; difficulties will, doubtless, be great at the beginning, but light will come little by little, and time will teach us surely to distinguish certain distinctive characteristics, whose expression will be gradually more and more simple. This is a work for the future.

* See Vivien, in the Mémoires de la Socièté Ethnologique, vol. ii, p. 59.

+ Portfolio, Philadelphia, 1814.

‡ W. Edwards, Des Caractères Physiologiques des races humaines, p. 4., has especially noticed the great importance of external characteristics; he has only done wrong in excluding the hair, and attending solely to the form of the skull, which never concerns us when we endeavour to picture or recall to our mind the features of a man. 
Anthropology regarding man as a whole, classifiers ought not to neglect his psychological value. Although craniology is only an indirect appreciation of the same, few had ever thought, Linnæus excepted, of using the purely intellectual characteristics of races in order to assist them in classification, when all at once the American school gave an immense importance to these characteristics, and placed psychological varieties above all the material differences which can be observed in the configuration of the bony case of the skull. The American school has gone too far, for it is tangible forms especially which must furnish specific characteristics in the animal kingdom.

However this may be, we may willingly give a secondary value to the intellectual classification of the human race, although data are still wanting in order to establish one which can be considered as complete. We will even add that the characteristics of this order are the more authentic and the more precious since they are not the expression of a given moment, nor that of a certain number of individuals. They belong to a whole race.

We must seek for them in the literary remains of a people. These teach us surely, even after many ages have elapsed, about the mind, belief, and thoughts of their readers. The monuments of plastic art remain, even if they were a complete contradiction against their time, their epoch, the men who ordered them, and the crowd which now regards without understanding them.* A book, on the contrary, has no success except as it enters into the mind of a people,-except as the ideas which it expresses are those of all the world. Each book which is published, then (like the Mosaic books among the Jews, the Korán amongst the Mussulmen), is the true expression of the mind of a race at all the periods of its existence, even were it written in a language which is no longer spoken. The best Greek and Roman works, written for men of the same blood as ourselves, have remained classical. We must understand them, even at the present day, and we do understand them, because the thoughts which animated their authors are still our own. If, on the contrary, we wish to

* See Michelet, with regard to the paintings in the Sixtine Chapel, Histoire de France, Renaissance. 
penetrate into any foreign literature, it becomes a labour and a fatigue, we only reach it by making an abstraction of our thoughts and our ideas, by endeavouring to enter entirely, by a violent effort, into the life and feelings of another people.

Languages also have been considered capable of serving as a basis for the classification of the human race. Their importance has been largely discussed, and counts numerous warm partisans.* At their head we may perhaps mention Latham, who wishes the ancient history of mankind to be studied by languages, $\dagger$ and agreeing in Prichard's ideas about the production of intermediary hybrid races, he only sees this method of reading the history of the past, and he is quite naturally led to language, which seems to him to offer better conditions of resistance than physical characteristics.

It is true that philology, applied to anthropological research, is of immense assistance to it; it can give us powerful inductions on the history of the past, and on the origin of the present human species. But even these solutions agree very well with the theory of gradual evolution, and with the corollary of this theory, namely, that man has not always possessed the faculty of speech. $\S$ Philologists tell us, for instance,

* "Philology is at once the most elevated and the most positive branch of the natural history of the human 1ace." Chavée, Moïse et les Langues (La Revue). M. Flourens seems to give philological a superior rank to physical characteristics. [See above, p. 77, note.-EDITOR.]

+ He believes that by their means we can go back to the most distant geological periods. See Apophthegms (Edinburgh New Philosophical Journ., vol. li.)

I Latham thus explains it: "This is because whilst $\mathbf{A}$ and $\mathbf{B}$, in the way of stock-blood or pedigree, will give $\mathrm{c}$ a true tertium quid, or a near approach to it, and $\mathbf{A}$ and $\mathbf{B}$, in the way of language, will only give themselves, $i$. e., they will give no true tertium quid, nor any very close approach to it." Celtic Nations, p. 33. We have endeavoured to prove that this true tertium quidthis real mean term, is never produced as far as species.

$\S$ ["Either language must have been originally revealed from heaven, or it must be the fruits of human industry. The greater part of Jews and Christians, and even some of the wisest Pagans, have embraced the former opinion, which seems to be supported by the authority of Moses, who represents the Supreme Being as teaching our first parents the names of animals. The latter opinion is held by Diodorus Siculus, Lucretius, Horace, and many other Greek and Roman writers, who consider language as one of the arts invented by man. The first men, say they, lived for some time in woods and caves, after the manner of beasts, uttering only confused and indistinct noises, till, associating for mutual assistance, they came by degrees to use articulate sounds mutually agreed upon, for the arbitrary signs or marks of those ideas in the mind of the speaker which he wanted to communicate to the hearer. This opinion sprung from the atomic cosmogony which was 
that two sister tribes may have been able, at some past time, to create on each side of a mountain two different idioms, which may produce in their turn two families of languages absolutely irreducible one from the other. This is what would take place, according to M. Renan, when the sons of the same parents, separating on the sides of the Imäus, became the double branch from whence have sprung the Semites on one side, and the Aryas on the other. This would be the explanation of the fact so embarrassing for anthropologists, that physical characteristics are sensibly identical among the Semites and Europeans, whilst these races are as distinct as possible in the matter of language. Now, we may even go further, and infer from these facts that the common species from whence the Semites, on the one hand, and the Aryas, on the other, are descended, did not yet know how to speak.

Inversely to Latham, some anthropologists have given, in our opinion, too little importance to language: we speak especially of Edwards and M. Omalius d'Halloy.* The truth lies, doubtless, between these two extremes. It must be acknowledged that language can very often furnish excellent evidence, but it must not be forgotten that it shows at the same time a more rapid liability to change than moral characteristics and corporal form. Niebuhr seems to us to be right when he insists upon the precautions to be taken in order to apply philology in a useful manner to the determination of races, and he concludes that we must give the greatest attention to physi-

framed by Mochus, the Phœnician, and afterwards improved by Democritus and Epicurus; and though it is part of a system in which the first men are represented as having grown out of the earth, like trees and other vegetables, it has been adopted by several modern writers of high rank in the republic of letters, and is certainly in itself worthy of examination." -Encyclop. Brit., vol. ix, p. 530, 1797.-EDITor.]

* I do not here mention the opinions of the Swede (see Latham, Celtic Nations, p: 2), who thinks that important changes can be introduced into a language by certain customs of a people, who change, for instance, the lips for the nostrils, and thus substitute nasal for labial consonants. These facts are, perhaps, true in the detail, but they ought not to have much importance, as they do not alter the specific and personal character of the language, which is far from consisting in the relative number of one or two kinds of letters. 
cal configuration.* This is also the opinion of Humboldt $\dagger$ and M. Vivien. $\ddagger$ A language, like every custom, and every act of individual relation, can transmit itself from one race to another which is very different. The unity of a family of languages is not always sufficient to establish that the people who speak these idioms are of one and the same origin; we can only conclude from it that they have been in relation one with the other, and it is even reasonable to admit that this cause has been able to act with a decisive influence at the epoch when man first commenced to lisp. $\S$ These two tribes meeting for the first time, physically strangers one to the other, were doubtless able to borrow mutually certain habits, and to mingle in a decided manner their two manners of explaining their thoughts, from which has resulted one sole language, in which we cannot distinguish except by analysis the two different branches which have contributed to its formation. This hypothesis has been even elevated to a general thesis by several philologists, and M. d'Escayrac de Lauture, among others, believes that the centre of Africa, that land of the unknown and of mystery, is reserved to us as a spectacle of this phenomenon. $\|$ Without going back to origin, it is evident that two neighbouring peoples, in continual relation one with the other, ought to end by borrowing mutually the forms of language, letters, and articulation, especially when they have neither of them any litera-

* Bunsen (Eng. transl.), Niebuhr's Life and Letters, vol. i, p. 39.

+ "Languages," he says, "give but feeble probabilities in Anthropology." Voyage aux regions Equinoxiales du Nouveau Continent, vol. iii, p. 352.

I See, in the Mémoires de la Société Ethnologique (July 1843), a letter in which M. Vivien denies a first rank to language as a distinctive characteristic, and gives it to physical type.

$\S$ See above, p. 32.

II "I am led to believe that familiar languages (if this philological barbarism is permitted $\mathrm{me}$ ) do not resemble one another because they come from the same parent, but because they have been brought up together; Africa especially seems to me to furnish a proof of it, for we must study the history of families of languages, especially in the place where they began to be formed, and I believe that language was formed in Africa. My hypothesis is not applicable to all cases, but to several; thus, the French, Italian, Spanish, etc., come from the Latin, and were born at its death; but many other languages appear to me to take their features one from the other by simple frequentation, by the natives being often in company together, and, as time goes on, these mutual loans make two or several languages, like the branches of the same tree, only, in my idea, the tree does not exist."-Correspondence, 1857. 
ture capable of retaining the language within its limits, and of preserving it from all separation.

Hence it results that anthropology must take its most precious authorities from the study of languages, in the language of the islands, for instance, and in the idioms spoken at the extremity of the continents: thus surrounded by the sea, in relation by its less extent with the others, these idioms will be preserved even more intact. We shall find here the real expression of the most ancient state of things which we can directly recognise by philology. The click language, so peculiar to one single race,* exists only in the most southern part of Africa. They still speak the ancient Pali† in the south of Asia and at Ceylon. The most ancient language of Europe, so far as we know, namely the Celtic, still remains in Britanny and in Wales.

From all which has gone before, we may then conclude that in order to establish a rational classification of human species, the first characteristics to be considered will be the external aspect, and perhaps the moral characteristics; the rest will come in the second rank: at first, language, then deep anatomical varieties which do not strike us at the first glance, then physiological and pathological varieties, etc. Such is, we think, the only certain basis upon which anthropology can rest-the true distinctions between human species. We do not even yet know exactly their number, and naturalists do not at all agree on this subject; the work is to be done over again, by following a new route.

Without troubling ourselves with enquiring into the whole system of the genus homo, we must at first examine these wellcharacterised centres of population which are entirely distinct as regards aspect and physiognomy. We must mark these centres with care, paying attention to all the physical, moral, and philological varieties which we are able to notice. M. Flourens has given some excellent principles for the study of animal species; he wishes simply to apply them to the study of human

* See above, p. 78.

$+[$ Pali, the ordinary language of daily life in Hindoostan at the time when Sanscrit was used in elevated literature alone.-EDITOR.] 
species; and from this connection, which nobody can contradict as a means of investigation, there arises a farther proof of the rank which we must give to man in the organic series. "We must observe the living animal," said M. Flourens; "we must observe him for a long time, and also both sexes and all ages. We must study his nature, his instincts, and his intellect. Each of these things has its own characteristic in each animal, and it is by the whole of these characteristics put together that species is defined." It is impossible to trace in a better manner the anthropologists' task.

When we have well studied a homogeneous centre of popu- lation under all its aspects, when we have rendered an account of its physiological, psychological, and philological characteristics, we may stop; and without prejudging anything concerning the area of this race, may then pass on to another centre, which we shall notice in the same way, without troubling ourselves with intermediary varieties, which will always be in a greater or lesser number wherever we do not happen to meet with a physical barrier, like the sea or a chain of mountains, which may separate the two centres which are to be observed. Then we shall, doubtless, have numberless shades and transitions; but these are merely the phenomena of hybridity, entirely secondary, and which ought not at all to influence our essays on anthropological classification. At a later period, when we know more, we shall be able to review all these intermediary varieties, when we understand their conditions of existence better. In this manner we must take care at the beginning to study certain countries, places of travel, and meeting, to which all the neighbouring races have given some portion of their blood. Such are most European countries, and such always was the Valley of the Nile and the Blue Nile. The streets of Cairo are not only a picturesque spectacle; from thence did Etienne Geoffroy borrow his grand views about the position of the genus homo in nature; the man of science profits here as much in his search after truth as the artist in his search after the beautiful.

Who can forget, even if he has only once seen it, this phantasmagoria of customs and physiognomies which developes itself 
before our eyes at every moment; here a gigantic Circassian, there a smaller sized Copt, with an arched nose; a Nubian, with his "violet ebony" colour, but with a pleasing figure, nose straight and small, thin lips, well arranged teeth; a Turk, with as white and transparent a skin as a man of the north; a Negro, with crisped hair, flat nose, prominent cheek-bones, thick lips, large and projecting teeth; a Fellah, with olive complexion; a Bedouin, almost as black as a Nubian, but tall, with aquiline nose, thin lips, and kingly bearing.

We must not seek for a pure population in the streets of Paris, London, Marseilles, Trieste, or Constantinople : we only find in these capitals isolated facts, good specimens, perhaps, of different species, but lost in the multitude of hybrids. We can only study in these places individuals, not species. In those parts alone which we must make centres of observation, can we see the same man indefinitely multiplied among really primitive people, still free from intermixture, or with the least possible taint of the same. Then we must hasten to seize his general characteristics, and take both his physical and moral portrait.

The physical portrait in particular comprises two series of data, features and colour. As to feature, photography is an unequalled resource, but it belongs to anthropological study to settle its application in a clear manner: we must always choose some individual presenting the usual type of the population in the midst of which he is found, rather than among the chiefs or nobles of the land. We must select this type in the prime of life, when the animal œconomy has arrived at its perfect development, and has not yet commenced to decay, and still shines in all the splendour of its reproductive force; this would be, for man, from twenty-two to twenty-seven years of age. For photographic portraits to be of real utility to anthropologists, they ought to represent the individual completely full face, or in profile; thus only can they be of use in measurements. For it is important not to confound anthropology with ethnology, as is done every day. They are two things entirely different. Dressed-up portraits are the domain of the latter, the natural history of man demands always absolutely nude 
representations, and the best will be those which show us the individual with untouched beard and hair.

As to colour, we must refer as much as possible to oil-painting. In fact, the colour of the human skin, as we have formerly said,* is, in reality, a complex visual impression; all the coloured rays (we employ the term here in the conventional sense given to it in physics) which emanate from the skin, and which strike the eye of the observer, are not formed by the same plane surface; they arise from the more or less profound parts seen by transparency, through a more or less diaphanous medium, more or less favourable for the emission of these rays. Hence results, as regards the eye, a special sensation, and as regards the mind, a special notion, which we explain in the arts by the word transparency or diaphaneity.

Now, this kind of sensation will not be reproduced by the artist unless he employs certain processes recalling to the mind those of nature itself. This is not the case with watercolour painting. The colouring matter, reduced to extremely fine particles, is applied, it is true, in a transparent vehiclewater; but this, destined to evaporate almost immediately, leaves the colour on the surface of the paper, stretched into an extremely fine layer, without appreciable thickness. We perceive from this the radical imperfection of water-colour for portraiture, and the impossibility of rendering by such means, at least with truth, the effect of skin colours. Oil painting offers far better resources, and here is the secret of its incomparable superiority. The colouring matter, diluted by the oil, remains suspended as before in its transparent medium when the painting is dry; so that the luminous rays, in order to arrive at the eye, start from the surface of the paint as well as from its interior substance. We find exactly the same process in nature ; an impalpable powder, like the pigmentary granulations, or the globules of blood in the capillaries of the skin, is spread over a diaphanous substance.

We may now understand the advantage of such a process in anthropological iconography. We must, indeed, almost give 
up all other methods. It is easy to convince oneself of the fact by examining the coloured portraits which illustrate the works of Prichard,* Nott, and Gliddon, $\uparrow$ who are, however, extremely particular about the correctness of the types which they bring before our notice. But all these coloured portraits are unsatisfactory, and when we see some anthropologist invoke the authority of these bad prints, we really ask ourselves which we ought most to admire, either the blind confidence of the savant, the imprudence of the author, or the rashness of the artist. Fancy, however, attacking with such platitudes the portraits of dark-coloured men which the masters of painting have left us, from Veronese to Gericault! They alone have been able, by their process, to seize the reality of the complexion and colour of their models. $f$

But the surest method of arriving at conclusive evidence in anthropology is necessarily travels. Doubtless the study alone of the materials collected from afar is of the greatest possible use. But we repeat concerning the study of mankind what we said about the study of animals; the anthropologist must leave his library and go into the great continents, in order to study by means of his own eye-sight. "We can only arrive at the distinction of species," says M. Flourens, "by direct and complete personal observation." That it must be complete, we have endeavoured to show; but the only condition for its being complete is its being direct. Had we even the genius of Buffon, $\S$ we should see but poorly by means of others; facts reach us distorted and altered, because they have not always been observed by competent men; they are not comparable,

* See The Natural History of Man, 1844.

+ See Ethnographic Tableau (Indigenous Races of the Earth, London, 1S57).

¥ We may quote, as types of genus, two paintings, incomparable in an anthropological point of view, Portrait d'un Nègre ; Portrait d'un Oriental, by Herschop (Berlin Museum, Nos. 825 and 827).

$\S$ M. Flourens, in saying that Buffon collected the accounts of different travellers in order to write his Histoire des Races, adds, "Whatever they have only seen with the eyes of their body, he sees with the eyes of his mind, and by that means alone he sees better than they can; each of them has seen merely some scattered characteristics,-Buffon sees everything; he links together whatever they may have separated, and separates whatever they have confounded."-Histoire des Idées de Buffon, p. 167. 
resulting as they do from diverse individual impressions. It will be especially necessary to control with care travellers' tales as regards the study of intellectual tendencies, since they are too often influenced by their own ideas on the subject.

Let us say this before concluding: among the $\grave{a}$ prior $i$ proofs which polygenists can bring forward on their side, there is one which is of some importance; it is this, that while contrary ideas have been sustained and defended by men who never go beyond their own studies, the former have been generally brought forward by travellers and sailors, by those indeed who have been best able to put in practice this direct observation, which is generally conclusive and decisive. It is these whom we find the most ready to separate mankind into distinct groups, and to recognise in the inferior species a manifest tendency to approach nearer the nature of the anthropomorphous apes. A valuable source of information, from which anthropologists must not neglect to borrow, are the accounts of those who landed for the first time on certain islands and continents.

If they have even conceived any erroneous ideas, it must usually be acknowledged that they are most likely to be able to give us a tolerably faithful portrait of the nations with whom they have met, even more important in certain points of view than the accounts afterwards given of them, since at that time these people have not been submitted to the various influences which necessarily result from contact with Europeans.

We can study philology and craniology in the library and in solitude, assisted by proper documents and sufficient materials, but not anthropology; because anthropology is a science still in its cradle, and observation must have furnished its proper and necessary contingent before we can endeavour to apply any general idea or view. But anthropology ought, more especially, to disengage itself from all trammels of former ideas, as well as from all pretended humanitarian tendencies. It would be nonsense to believe that the advance of the truth will not contribute to social progress. The searcher after it can free himself in all tranquillity of mind from this kind of trouble. Haller has said, in reference to this matter, "The 
cultivation of truth alone is sufficient for the good man."* That which is true, $\dagger$ cannot be evil, because it is in the eternal order of nature.

Thus, free from fetters, and obeying pure reason, resting on all the sciences which can assist it, anatomy, physiology, psychology, and philology, the science of mankind will advance, like every other science, towards the conquest of that truth which is so much to be desired; and sooner or later, by means of archæology and palæontology, retracing its steps in the past beyond history itself, and beyond the remotest geological epochs of which we have any record, science will eventually discover the grand problem of the origin of mankind, if the elements themselves are not for ever engulphed in the depths of the ocean.

* "Boni viri nullam oportet esse causam præter veritatem."

+ [Yes, but the difficulty is to determine if it is true. We cannot receive anything as true merely because a savant says it is so. We must go on enquiring in a proper spirit; but we must not put inquiry after truth in the same category with scepticism,-- "that cheerlessness of soul to which certainty respecting anything and everything here on earth seems unattainable." This is the age for seeking after truth; but in how many different ways do men endeavour to attain to it! We must search the past carefully in all its scientific and natural facts, and as Longfellow beautifully says,-

"Nor deem the irrevocable past, As wholly wasted, wholly vain,

If, rising on its wrecks, at last

To something nobler we attain."

This is the true aim of all inquiry.-EdrTor.] 



\section{INDEX OF SUBJECTS.}

Aborigines, 54

Abou Simbel, 50

Abyssinia, 57

Acclimatisation, 58, 89

Aërolites, 112

Africa, Central, inhabitants of, 14, 68

African equality with European, 8

Age of the world, 122

Aldridge, Ira, 63

America, 6, 67, 74.

Anatomy, human, 13

Angles of the skull, 137

Anoplotherium, 4.2

Anthropological Societies of Paris and London, 7

Anthropomorphous apes, 11, 41

Antilles, 56

Ants, 33

Arabs, 47

Aryan family, 19, 131, 143

Asiatic tribes, 18

Australia, 14, 67

Australian aborigines, 5, 16, 17, 44.

Babel, Tower of, 5

Bedouin, 147

Bees, 33

Bigenerate hybrids, $\_6$

Bimana, order of, 38

Blood, 53

Bosjesmans, 55, 79

Bourbon, Isle of, 87

Bowed legs, 47

Brain, 12

Brazil, 69

Brute and man, 19

Buddha, 52, 67, 71

Caffres, 68, 79

Cairo, 146

Caakhya-Mouni, 52

Ćaledonians, 103

Cartesian theory, 26

Causæ degenerationis, 90
Central America, 81

Chain of gradation, 37

Chinese, 5, 53, 78

Circassia, 147

Classification, 64, 135

Climate, 92

Clitoris, 54

Colour, 148

Consanguinity, 107

Consciousness, 12

Copts, 1477

Cordilleras, 66

Craniology, 138

Crétins, 106

Crocodile, 128

Cross-breeding, 97

Danelag, 104

Degraded nations, 75

Desdemona, 63

Development of animals, 15

Dhargonis, 18

Disease, 58

Dog, 34

Earth, motion of, round the sun, 6

Egyptians, 49, 139

England, 103

Esquimaux, 15, 17, 18, 53, 54, 68, 75

Eurygnathi, 45

Evangile de l'Enfance, 64 .

Evolution, 122

Family of man, $4: 2$

Fellah, 147

Flinder's Island, 97

Flood, the word, 122

Foot, 49

Forearm in Negro, 48

France, ethnology of, 104.

Frugivorous man, 39

Gallic mummy, 139

God, belief in, 71 
Good and evil, 23

Goths, 62

Gradation, chain of, 37

Grecian theories, 81

Hair, colour of, 50,52

Half-castes, 98

Hamites, 131

Harems, 101

Height, differences of, 47

Hindoostan, 40, 145

Hippopotamus, 128

History, 80

Homoïdes, 98

Host, elevation of the, 66

Hottentots, 68

Human kingdom, 10

Humanitarian considerations, 73

Hybridity, 95

Iconography, 148

Ilotes, 84

Index, the congregation of the, 6

Individual-element, 124:

Intelligence of $\operatorname{man}, 12$

Japanese, 5

Jesus, 64

Jews, 70, 89

Korán, 1, 141

Labrador, 101

Language, 30, 33, 142, 145

Leucous, 51

Lima, 105

Linear series, 10

Lions, 128

Man and brute, 18

Marsh fever, 59

Material substance, 12

Mathesiological order of science, 2

Mechanical theory of mind, 26

Mediæval science, 1

Medium, action of, 82

Melanesians, 57

Melanocomous, 51

Monkey-countenance, 56

Monkey-people, 18

Monogenists, 3 , 80

Monotheism, 66

Moral sense, 23

Mosaic statement, 114, 141

Namaquas, 68

Natural selection, 119

Negroes, 5, 39, 44, 48, 52, 53, 54, 58, $59,60,63,64,86,147$

Neo-Platonists, the, 2
New Guinea, 40

Nicaragua, 106

Niger, 59

Nile, 68

Nile-boats, 39

Noah's curse, 50

Norma verticalis, 136

Normans, 101, 13

Nubians, 39, 101, 147

Official science, 113

Orang-outang, 19, 20, 22, 24, 41

Orthodox ethnology, 5

Orthognathi, 45

Othello, 63

Palæontology, 131

Pali, 145

Pandora, 133

Pathological varieties, 43, 58

Pelvis, form of, 46

Penis, 54

Peruvians, 55

Phidias, 5

Physiological varieties, 43

Polygenists, 3

Praxiteles, 5

Prepuce, 54

Prognathi, 45

Prometheus, 133

Protozoa, 111

Psychology, comparative, 24, 36

Races, 65

Reason and faith, 23

"Records of Creation," 37

Religious dogmas, 9, 65, 67, 85

Reproduction by eggs, 111

Réunion, Isle of, 88

Revealed religion, 2

Revolution, 122

", relations with science, 4

Riff, 89

Rosin-makers of the Landes; 39

Scandinavian antiquities, 48

Scriptures, the Holy, 1

Selection, natural, 118

Self-consciousness, 28

Semitic race, 1, 53, 65, 75, 89, 143

Sidereal kingdom, 11

Sierra Leone, 41, 93

Silurians, 103

Slaves, 84

Soudan, 45, 61

Soul in animals, 25

South Africa, 78

Spaniards, 47

Species, definition of, 108

Speech, 30 
Sperma, 53

Spontaneous generation, 110, 123

Squatting attitude, 57

Stags, 85

Stirrup leather, 39

Struggle for existence, 102

Sumatran animal, 21

Sunburn, 91

Tartars, 47, 54

Thomas, St., 69

Toe, great, 39,42

Truth, the reign of, 9, 23

Tuân, an orang-outang, 20

Turk, 147

Type, 99

Valmîki, poem of, 40
Vanikoro, 49

Variability of species, 115

Vera Cruz, 61

Vertebrate kingdom, 125

Vital competition, 128

Voice in animals, 34

Vulcan, 133

Wild man of the woods, 14

Woolly hair, 51

Xanthus, 51

Yellow Ferer, 94

Zamboes, 105

Zoology, 65, 85, 109 
INDEX OF AUTHORS.

About, 63

Agassiz, 113

Albin, 44

Albinus, 86

Apollonius, 35

Appleyard, 79

Aristotle, 2, 28, 37, 53

Arnold, 59, 94

Baeck, 44.

Bancroft, 60

Barrière, 44

Bartlett, 59

Barton, 94

Bayle, 4, 28

Beavan, 59, 88

Bérard, 20, 45, 46, 50

Bert, 11

Bertillon, 5, 68

Bertrand de Saint-Germain, 120

Biot, 6

Blainville, 37, 38, 41, 109, 135

Blair, 60, 93

Blake, Carter, 57, 65, 85, 110

Blumenbach, $3,90,98$

Bonaparte, 38, 42

Bonpland, 6

Bonnet, 15, 37

Bonté, 84

Bory de Saint-Vincent, 17, 39, 50, 88

Bossuet, 12

Boudin, 58

Bourdet, 3, 88, 91, 97

Brayley, 7

Brecher, 70

Broca, 3, 35, 48, 110, 137

Brunet, 64

Bryant, 60

Brydone, 122

Büchner, 66

Buffon, 21, 28, 102, 111, 113

Bunsen, 11, 144

Burnouf, 30, 52

Busk, 137
Cabanis, 81, 106

Caldwell, 140

Cameron, 59

Camper, 46, 134, 136

Carus, 50, 63

Charles IV, 6

Charnock, 77

Chavée, 77, 142

Chevreul, 8, 23, 35

Chrysostom, Saint, 25

Cohen, 76

Collingwood, 66, 91

Cook, 56

Coombes, 77

Copernicus, 6

Coréard, 57

Courtet de l'Isle, 14, 100

Crawfurd, 40, 52

Crocius, 26

Crull, 136

Cull, 104

Cuvier, Frederic, 25, 28, 38, 41, 42

Cuvier, G., 38, 41, 42, 82, 83, 109 , 112

Dally, 88

Darwin, 110, 115, 118, 126

Davis, 92

Davy, 48

D'Eichthal, 54, 62

Descartes, 4, 12, 26

D'Escayrac de Lauture, 75, 144

De Maillet, 63

Desmoulins, 15

Dickinson, 94

Dickson, 94

Didot, 111

Doornick, 136

D’Orbigny, 74, 77

Durer, 48

Earl, 52

Edwards, 89, 99, 100, 140, 143

Ehrenberg, 19 
Epianus, 7

Epp, 59

Fauche, 40

Fée, 110

Fenner, 60

Ferguson, 94

Fleury, 5

Flourens, 20, 27, 28, 30, 37, 44, 98, $107,115,142,145$

Galen, 13

Galileo, 3, 6

Garnot, 16, 104

Génébrard, 71

Geoffroy St.-Hilare, Barthélemy, 71, 97

Geoffroy St.-Hilaire, Etienne, 4, 17, 20, $27,38,39,109,114,132,146$

Geoffroy St.-Hilaire, Isidore, 11, 12, $20,34,38,39,79,81,83,84,87,95$, $109,110,113$

Géricault, 56

Geulinx, 27

Gibson, 34

Gliddon, 63

Gobineau, 3, 63, 105

Godron, 110

Grandsagne, 48

Grant, 20, 24

Gratiolet, 30

Gray, 66

Grimm, 30

Gros, 27

Guillain, 42

Hale, 16

Haller, 56

Hanneman, 50

Harris, 49

Hasskarl, 66

Herder, 30

Herrera, 60

Herschop, 149

Heymann, 59

Hippocrates, 81

Hirsch, 59, 60, 93

Holsteinius, 26

Huber, 33

Humboldt, 6, 19, 55, 57, 66, 77, 84, 144

Hunt, 63, 77

Hunter, 59, 90

Huxley, 39

Jackson, 60

Jacquinot, 53, 97

Jobin, 59

Josephus, 70

Joulin, 46

Jouvencel, 5

Julius Cæsar, 103
Kaempfer, 5, 6

Karr, 7

King, 6

Kirchoff, 11

Klemnius, 27

Kluegel, 44.

Knox, 43, 54, 81, 100

Lallemand, 94

Lamarck, 112, 115

Lartet, 121

Latham, 66, 78, 101, 104, 142

Laugenhert, 27

Lawrence, 45, 48

Le Cat, 44, 56

Leibnitz, 15, 37, 120

Leighton, 68

Lepsius, 50

Lesseps, 68

Lesson and Garnot, 16, 20, 25

Linnæus, 37, 41, 64, 102, 109

Livingstone, 68

Longfellow, 151

Maire, 26, 28

Malte-Brun, 59

Martius, 74

Maupertuis, 20, 29, 34

Maury, 22, 46, 49

McCabe, 59

Meckel, 44

Meigs, 137

Mercurius Trismegistus, 36

Michelet, 126, 141

Mitchell, 44, 86

Montagne, 13

Morel, 74, 79, 81, 90, 97, 100, 106

Morton, 76, 110, 134, 137, 138

Mulders, 136

Müller, 77

Newton, 76

Niebuhr, 73, 89

Nott, 50, 60, 97, 110

Omalius D'Halloy, 143

O'Rourke, 17

Owen, 20, 36, 38, 42, 135

Palissy, 137

Pallas, 48, 54

Pardies, 32 .

Parker, 66

Pereira, 26

Périer, 87, 98, 104

Philips, 104.

Piddington, 17, 18

Plato, 4, 22, 122

Plutarch, 111

Polybius, 81 
Porphyrius, 26

Pouchet, 50, 123

Prichard, 3, 51, 78, 100, 129, 134, 142

Proudhon, 5, 8, 24

Prout, 114

Pruner-Bey, 50, 51

Pucheran, 8

Pyrard, 41

Pythagoras, 26

Quatrefages, 1, 4, 11, 12, 13, 17, 20, 23,27

Quekett, 137

Quoy and Gaimard, 17, 49

Rechtenbach, 25

Remusat, 65

Renan, 32, 64, 65, 76, 78, 143

Robertson, 35

Robin, 20, 56, 84

Romay, 94

Ross, 17, 18, 53, 54, 69, 75

Roulin, 34

Schlegel, 73

Schmidt, 66

Schnurrer, 58

Schomburgk, 94

Shoutten, 41

Serres, 6, 8, 54, 62

Servetus, 1

Smith, Hamilton, 4, 51, 53

Sömmering, 44, 46, 56

Speke, 62

Squier, 105

Stahl; 27

Steinthal, 31, 32

Strabo, 103

Sumner, 37

Strope, 139

Tacitus, 103

Thomas, Saint, 69

Thomson, 59

Thurnam, 104

Tidyman, 59

Tiedemann, 43

Toussenel, 33

Townsend, 93

Trail, 19

Tschudi, 59, 105

Verneuil, 84

Vitruvius, 81

Vivien, 140, 144

Voltaire, 7

Vrolik, 46

Wagner, 44, 106

Waitz, 9

Warren, 97

Weber, 46

White, 46, 79, 88

Whitebourne, 69

Wied, 88

Wilkes, 17

Wilson, 48

Wise, 92

Yvan, 20, 87

Zimpel, 94

Zobrega, 69.

\section{ERRATA.}

Page 122, line 11 from bottom, for "Atalantis" read "Atlantis.

" 135, bottom line, for "British Association for the Advancement of Science, 1857," read " Journal of Linnean Society, 1857." 


\title{
Antbrapological Society of zlondon,
}

\author{
4, ST. MARTIN'S PLACE, TRAFALGAR SQUARE.
}

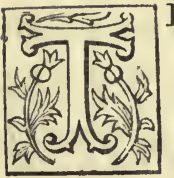

HIS SOCIETY is formed with the object of promoting the study of Anthropology in a strictly scientific manner. It proposes to study Man in all his leading aspects, physical, mental, and historical ; to investigate the laws of his origin and progress; to ascertain his place in nature and his relations to the inferior forms of life; and to attain these objects by patient investigation, careful induction, and the encouragement of all researches tending to establish a de facto science of man. No Society existing in this country has proposed to. itself these aims, and the establishment of this Society, therefore, is an effort to meet an obvious want of the times.

This it is proposed to do :

First. By holding Meetings for the reading of papers and the discussion of various anthropological questions.

Second. By the publication of reports of papers and abstracts of discussions in the form of a Quarterly Journal; and also by the publication of the principal memoirs read before the Society, in the form of Transactions.

Third. By the appointment of Officers, or Local Secretaries, in different parts of the world, to collect systematic information. It will be the object of the Society to indicate the class of facts required, and thus tend to give a systematic development to Anthropology.

Fourth. By the establishment of a carefully collected and reliable Museum, and a good reference Library.

Fifth. By the publication of a series of works on Anthropology which will tend to promote the objects of the Society. These works will generally be translations; but original works will also be admissible.

Translations of the following works are now ready.

Dr. Theodor Wartz. Introduction to Anthropology. First Part. Edited from the German by J. Frederick Collingwood, Esq., F.R.S.L., F.G.S., Hon. Sec. A.S.I., with corrections and additions by the Author. Price 16s.

Broca, Dr. Paul. On the Phenomena of Hybridity in the Genus Homo. Edited from the French by C. Carter Blake, Esq., F.G.S. Price 5s.

Pouchet, Georges. On the Plurality of the Human Race. Edited, from the French (Second Edition), by H. J. C. Beavan, Esq., F.R.G.S., F.A.S.L. 
The following work is in the press and will be delivered to all Fellows for the year 1864:-

Carl Vogt. Vorlesungen über des Menschen, seine Stellung in der Schöpfung und in der Geschichte der Erde. Edited by Dr. James Hunt, F.S.A., Pres. A.S.L. 8vo, Giessen, 1863.

The Translation of the following works is contemplated:-

Blumenbach, J. F. De Generis Humani varietate nativa liber. Edd. 1775, 1781, 1790. And other works. By T. Bendyshe, Esq., M.A., F.A.S.L.

Gratiolet. Mémoire sur les Plis Cérébraux de l'Homme et des Primates. 4to, Paris, 1855. Edited by Dr. Daniel H. Tuke.

A. De Quatrefages. Unité de l'Espèce Humaine. Edited by G. F. Rolph, Esq., F.A.S.L. 8vo. Paris, 1861.

The Anthropological Papers contained in the Comptes Rendus des Séances de l'Académie des Sciences. Edited by George E. Roberts, Esq., F.G.S., F.A.S.I.

Dr. Theodor Wartz, Professor of Philosophy in the University of Marburg. Anthropologie der Naturvölker. 1861. Second part. Edited by J. Frederick Collingwood, Esq., F.G.S., F.R.S.L., Hon. Sec. A.S.L.

Gosse. Mémoire sur les Déformations Artificielles du Crâne. 8vo. Paris, 1855.

Retzius, Professor. The collected works of.

Bory de St. Vincent. Essai zoologique sur le genre humain. 2 vols. Paris, 1827.

Crull. Dissertatio anthropologico-medica de Cranio, ejusque ad faciem ratione

8vo. Gröningen, 1810.

Sixth. By the appointment, from time to time, of various Committees authorised to report to the Society on particular topics which may be referred to them; the results of such investigations being in all cases communicated to the Society.

\title{
OFFICERS AND COUNCII FOR 1864.
}

\author{
President. \\ Society of Paris, etc. \\ Vice-Presidents. \\ Captain Richard F. Burton, H.M. Consul at Fernando Po, etc. \\ Sir Charles Nicholson, Bart., D.C.L., LL.D., F.G.S., etc. \\ The Duke of Roussillon.
}

James Hunt, Esq., Ph.D., F.S.A., F.R.S.L., Foreign Associate of the Anthropological

\section{Honcrary Secretaries.}

J. Frederick Collingwood, Esq., F.R.S.L., F.G.S., Foreign Associate of the Anthropological Society of Paris.

George E. Roberts, Esq., F.G.S.

\section{Honorary Foreign Secretary.}

Alfred Higgins, Esq., Foreign Associate of the Anthropological Society of Paris.

\section{Treasurer.}

Richard Stephen Charnock, Esq. F.S.A., F.R.G.S., Foreign Associate of the Anthropological Society of Paris. 
COUNCIL.

Hugh J. C. Beavan, Esq., F.R.G.S.

T. Bendyshe, Esq., M.A.

W. Bollaert, Esq., Corr. Mem. Univ. Chile, and Ethnological Socs. London \& New York.

S. Edwin Collingwood, Esq., F.Z.S.

George D. Gibb, Esq., M.A., M.D., LL.D., F.G.S., \&c.

Professor G. W. Leitner, Ph.D., M.A., F.R.A.S., \&c.

J. Norman Lockyer, Esq., F.R.A.S.

S. E. Bouverie-Pusey, Esq., F.E.S.

W. Winwood Reade, Esq., F.R.G.S., Corr. Mem. Geographical Society of Paris.

C. Robert des Ruffières, Esq., F.G.S., F.E.S.

Dr. Berthold Seemann, F.L.S.

William Travers, Esq., F.R.C.S.

W. S. W. Vaux, Esq. M.A., F.S.A., F. and Hon. Sec. R.S.L., President of the Numismatic Society of London.

Curator, Librarian, and Assistant Secretary.

C. Carter Blake, Esq., F.G.S., Foreign Associate of the Anthropol. Society of Paris, etc.

The Terms of Membership for the first five hundred Fellows (who will be called Foundation Fellows) are Two Guineas per annum, which will entitle every Fellow to admission to the Meetings, one copy of the Quarterly Journal, the Memoirs of the Society, and a Volume (or Volumes) of the Translations printed by the Society. Life Members, Twenty Guineas.

Further particulars will be forwarded on application to the Honorary Secretaries.

The following papers, amongst others, will be laid before the Society in the next Session.

Dr. JAmes Hunt, F.S.A., F.R.S.L., On the Principles of Anthropological Classification.

Edward Lund, Esq., F.R.C.S.E., and Dr. F. Royston Fairbank, F.A.S.L., On the

Discovery of Syphilis in a Monkey.

Dr. JoHn SHorTt, On the Leaf-wearing Tribes of India.

T. W. Pritchard, Esq., F.G.S., F.A.S.L., On Viti and its Inhabitants.

W. Bollaert, Esq., On the Astronomy of the Red Man of the New World.

A. Higgins, Esq., Hon. For. Sec. A.S.L., On the Orthographic Delineation of the Skull.

T. Bendyshe, Esq., M.A., F.A.S.L., On Early Anthropology.

W. Bollaent, Esq., F.A.S.L., Introduction to the Anthropology of America.

E. Burnet Trlor, Esq., F.R.G.S., F.A.S.L., On some British Kjökkenmöddings.

Captain Burton, V.P.A.S.L., A Visit to Dahomey.

C. Carter Blake, Esq., F.G.S., F.A.S.L., On the Cranioscopy of South American Nations.

C. Carter Blake, Esq., F.G.S., F.A.S.L., On the Form of the Lower Jaw in the Races of Mankind.

Dr. Murie, On the Stature of Tribes inhabiting the Nile Valley.

R. S. Channock, Esq., F.S.A., F.A.S.L., On the People of Andorra.

J. F. Collingwood, Esq., F.R.S.L., On Race-Antagonism. 


\section{PUBLICATIONS OF THE ANTHROPOLOGICAL SOCIETY.}

\section{Now Ready, in 1 vol., 8 vo., pp. 400 , price 10s., cloth, Waitz's Introduction to Anthropology. J. Flom the FrRS VoLUME of Anthropologie der Naturvolker, by of the Anthropological Society of Paris, Honorary Secretary of the Anthro- pological Society of London.}

\section{Extract of a Letter from the Author to the Editor.}

"I have received your translation of the first volume of my 'Anthropologie der Naturvölker,' and hasten to return you my heartfelt thanks for the great care and assiduity which you have bestowed on the task. I am fully cognisant of the great difficulties you have to contend with, especially as my style, as alluded to in your preface, possesses many peculiarities, so that even German men of science consider the reading of my books rather hard work. All these difficulties you have surmounted with the greatest skill, so as to render my work, as it appears to me, into very pleasing, readable English."

\section{OPINIONS OF THE PRESS.}

"A more felicitous selection could not, we conceive, by any possibility have been made than the very one which bus resulted in the publication of the book lying before us. For within the compass of the first volume of Dr. Waitz's Anthropologie der Naturvöllier is compacted together the most comprehensive and exhaustive survey of the new science yet contributed, we believe, in any tongue to European literature. To the English public generally, however, it is a book almost unknown, saving and excepting alone by reputation. Although merely a translation from the German, therefore, the work is virtually, if not un original work, a perfectly new work to the mass of readers in this country. So far as this same rapidly executed work of translation can be compared and collated with the original, it appears to be a version singnlarly faithful and accurate... The book, as it now appears, is a work of especial value, and also one of very peculiar interest. It thoroughly fulfils its design of affording the reader of it, within a single volume, the very best epitome anywhere to be found of what is the actual 'present state' of anthropological science in Christendom. Dr. Waitz takes a far wider range within his ken than Prichard and Nott and Gliddon com. bined."-The Sun, Dec. 14, 1863.

"The volume in every page exhibits great research; it abounds with interesting speculation, all tending the right way, and the information it presents is happily conveyed in a popular manner." -Morning ddvertiser, Nov. 16, 1863.

"So comprehensive is the view taken by the author of all that pertains to man, that a mere enumeration even of the leading topics of the work is beyond our space, and we must content our. selves with recommending its perusal to such of our readers as are interested in the subject, with the assurance that it will well repay the trouble." - Weekly Dispatch, Nov. 29, 1863.

"This handsomely printed volume discusses at great length and with much ability the question as to the races of man.... At the hands of Dr. Waitz it has met with calm consideration, and in its English dress will prove both interesting and instructive. It displays great research, and contains a large extent of highly interesting matter."Liverpool Albion, Nov. 9, 1863.

"From such a bill of fare, our readers will be able to judge that the work is one of value and interest. ... It is of the nature of a review, arriving at a comprehensive and proportional estimate, rather than at minute accuracy of detail, such as may be sought else. where in each department."-Medical Times, Dec. 26, 1863.

"Crammed as full of hard facts as wellnigh 400 pages of large $8 \mathrm{vo}$. can contain : all these facts attested by footnote authorities marshalled knee-deep at the bottom of every page; with a list of contents so copious as to eclipse everything of the kind in any recent scientific volume, and yet followed by an index more minute and ample; this work is a magazine of the infant science of Man; a model of German industry, 
PUBLICATIONS OF THE ANTHROPOLOGICAL SOCIETY.

erudition, and philosophical devotion; and a credit to the Society which has sent forth, in a shape so serviceable, what might otherwise have proved a tantalising mass of learned collectanea. ... We have perused this translated volume with alteruate wonder and amazement at its strange assemblage of facts, its curious classifications, its marvellous revelations of human peculiarities; and we do not hesitate to say that more food for speculation, a more cosmopolitan and comprehensive glance over all the developments of savage and civilised man has been collected here, than could have beer dreamed of by those who may not have given it a perusal."Dorset County Chronicle, Nov. 18, 1863.

"Dr. Waitz would appear to have collected together all the authorities and contradictory statements of former writers. ... The present work will be hailed with pleasure by all who are interested in the study of anthropology, and will, it is hoped, induce a more universal acquaintance with the science."-Observer, Nov. 8, 1863.

"The Anthropological Society of London have done well in publishing a translation of Dr. Waitz's Anthropo. logie der Naturvölker, of which this volume is the first instalment. Dr. Waitz's work is by far the most complete that exists on the subject of which it treats. It is the fullest collection of facts, interwoven with, and made to bear upon, all the theories (and their name is legion) which have been advanced in explanation of the endless diversities and resemblances that exist among mankind. Dr. Waitz himself is wedded to no particular theory, and in this volume, at least, advances none, but he points out with great clearness the effects that may be fairly attributed to the various influences, external and internal, physical and psychical, which affect the human form and national character."-The Press, Dec. 5, 1863.

"This volume will help to put the science of anthropology in a proper light before the scientific men of this country. Whatever faults we may have to find with this work, we feel sure that its publication marks an epoch in the study of anthropology in this country. The anthropologist can now say to the inquirer, Read and study Waitz, and you will learn all that science has yet to reveal."-AnthropologicalReview, No.3. "The Anthropological Society deserve great praise for the energy and activity they display in prosecuting their object. ... We find in this volume a fair statement and discussion of the questions bearing on the unity of man as a species, and his natural condition He gives a very clear account of the different views held on these questions, and a full collection of the facts, or supposed facts, by which they are supported. The chief fault of the book is, indeed, this very fulness and fairness in collecting all that can be said on both sides of a question.... We must regard the work as a valuable addition to the books on this subject already in our language, and as likely, by the thought and inquiry it must suggest, to promote the great end of the Society-a truer and higher knowledge of man, his origin, nature, and destiny."-The Scotsman, Dec. 7, 1863.

"We need hardly say, that it is quite out of our power to give any detailed account of this volume. It is itself a volume of details. Its nature, character, and value, may be gleaned from the criticism bestowed upon it by the Anthropological Society, and by the fact of its being their first offering to their members. There can be no doubt that it is the best epitome of matters anthropological now contained in our language; and will be of great service to the student as a book of reference." -British Medical Journal, December $26,1863$.

"The difficulties which a reader experiences who studies Waitz's original German version-difficulties attendant on the involution of his style, and the frequent mistiness of his forms of expression - vanish in the English edition, which aiso differs from its German prototype, inasmuch as the embarrassing references which Waitz intercalated in his text are prudently cast down by Mr. Collingwood to the foot of the page.... The student will but have to read it through, in order to feel himself endowed with an enormous power of acquired facts, which, if he duly assimilates, will enable him to wield a tremendous weapon in controversy against the unskilled anthropologist."-Reader, November 7, 1863.

London: Longman, Green, and Co., Paternoster Row. 
PUBLICATIONS OF THE ANTHROPOLOGICAL SOCIETY.

Now ready, in 1 vol. 8 vo, pp. 184, price 5s., cloth.

n the Phenomena of Hybridity in the Genus
HoMo. By Dr. PAUL BROCA, Secrétaire Général à la Société d'Anthropologie de Paris. Edited, with the permission of the Author, by C. CARTER BLAKE, F.G.S.

\section{OPINIONS OF THE PRESS.}

"Although the author of the essay can scarcely be supposed to have satis. fied himself-much less to have satis. fied his scientific readers-that he has arrived at any certain and well-grounded conclusion, he deserves the credit of having written with some research and acumen. It is evident that the writer of the book has a strong bias to the polygenist theory of the origin of mankind, but although we do not agree with him in his principal deductions and statements, we willingly allow his work to be an able monograph on a highlyinteresting and curious subject, and one that will well repay perusal."-Medical Times, March 1864.

"While we find fault with the conclusions at which M. Broca arrives, we cannot deny that he has given to the student of Anthropology a very valuable collection of information on an almost unexplored subject. We have only to guard ourselves from being led away by the specious fallacies of his reasoning, and we shall find before us a wide field of thought and a subject of enquiry almost inexhaustible. We need only add that the English edition has been pre. pared with great care, and reflects ex. treme credit upon its indefatigable editor." - Tablet, June 4, 1864.

"This is a work on a very abstruse and much-debated question, and the author has brought to bear upon its elucidation a vast amount of scientific research, being the results of observations in almost every part of the world." -Observer, April 10, 1864.

"It is wonderful what solid and valu. able information has been here com. pacted together within less than one hundred pages octavo. Another work of very considerable value has thus been added to the list of publications now commenced, with a prospect, let us hope, of fast multiplying into a substantial library, under the auspices and, more than that, under the careful supervision and at the direct instance of the Society of our London Anthropologists."-Sun, April 7th, 1864.

"As a statement of the argument on both sides of a subject very difficult of investigation, Dr. Broca's treatise is most acceptable, although we are by no means satisfied that he has entertained all the causes which may be concerned in influencing the fertility of races, inter $s e$, in his estimate."-London Review, June 4, 1864.

"The whole subject is too obscure to warrant us in advocating either the one view or the other; but we can recommend those who wish to make them. selves acquainted with the present state of our information on the question to study the able treatise before us."Scotsman, June 25, $186 \pm$.

"It may be stated that the present volume is the only one which completely investigates the subject of human hy. bridity........ The volume is an addition to scientific lore; we have no doubt that the members of our various learned societies will appreciate its worth, and experience the same pleasure in reading the translation which $\mathrm{Mr}$. Blake states he received when he first perused the original. It is dedicated as a testimony of respect and friendship to Richard Owen, F.R.S." - Morning Advertiser, May 2, $186 \pm$. 


\section{ANTHROPOLOGICAL REVIEW,}

Journal of the Anthropological Society of London.

VOL. I NOW READY, PRICE $13 s$.

(A few copies only remaining.)

\section{CONTENTS.}

On the Study of Anthropology. By Dr. James Hunt, F.S.A., President A.S.L.

Wild Men and Beast Children. By E. Burnet Tylor, F.A.S.L.

On the Tribes of Loreto in Northern Peru. By Professor Raimondi. Translated from the Spanish by William Bollaert, F.A.S.L.

A Day with the Fans. By Captain R. F. Burton, H.M. Consul at Fernando Po, and V.P.A.S.L.

On the Difference between Man and the Lower Animals. ByTheodor Bischoff. Translated from the German.

Summary of the Evidence of the Antiquity of Man. By Dr. James Hunt.

Huxley on Man's Place in Nature.

Jackson on Ethnology and Phrenology.

Lyell on the Geological Evidence of the Antiquity of Man.

Wilson's Pre-historic Man.

Pauly's Ethnographical Account of the Peoples of Russia.

Commixtare of the Races of Man. By John Crawfurd, Esq., F.R.S.

Burton's Prairie Traveller.

Owen on the Limbs of the Gorilla.

Man and Beast. By Anthropos (C. Carter Blake).

Dunn's Medical Psychology.

Human Remains from Moulin-Quignon. By A. Tylor, Esq., F.G.S. (Withan Illustration.)

Notes of a Case of Microcephaly. By R.T. Gore, Esq., F.A.S.L.

Notes on Sir C. Lyell's Antiquity of Man. By John Crawfurd, Esq., F.R.S.

Falconer on the reputed Fossil Man of Abbeville

Miscellanea Anthropologica.

Journal of the Anthropological Society of London.

On the Science of Language. By R. S. Charnock, Esq., F.S.A., F.A.S.L.

Fergusson on the Influence of Race on Art.

On the Creation of Man and Substance of the Mind. By Prof. Rudolph Wagner.

Pictet on the Aryan Race.

Ethnological Inquiries and Observations. By the late Robert Knox, M.D.

On the Application of the Anatomical Method to the Discrimination of Species. By the same.

On the Deformations of the Human Cranium, supposed to be produced by Mechanical Means. By the same.

History of the Proceedings of the Anthropological Society of Paris. By M. Paul Broca, Secretary-General.

On the supposed increasing Prevalence of Dark Hair in England. By John Beddoe, M.D., F.A.S.L.

The Abbeville Fossil Jaw. By M. A. de Quatrefages. Translated by G. F. Rolph, Esq.

Miscellanea Anthropologica.
On Cerebral Physiology.

Seemann on the Inhabitants of the Fiji Islands. By A. A. Fraser, Esq., F.A.S.L.

The relation of Man to the Inferior Forms of Animal Life. By Charles S. Wake, Esq., F.A.S.L.

Proceedings of Anthropological Society of Paris Anthropology at the British Association:Dr. Hunt on Anthropological Classification; Mr. Carter Blake on South American Cranioscopy ; Dr. Hunt on the Negro; Mr. W. Turner on Cranial Deformities: Mr. Duckworth on the Human Cranium from Amiens; Professor King on the Neanderthal Skull; Dr. Embleton on the Anatomy of a Young Chimpanzee; Mr. Carter Blake on Syndactyly; Mr. Roberts and Professor Busk on a Cist; Mr. Crawfurd on the Commixture of Man; Dr. Camps on Troops in India; Dr. Murray on Instinctive Actions; Mr. Samuelson on Life in the Atmosphere; Mr. Glaisher on the Influence of High Altitudes on Man; Mr. Hall on the Social Life of the Celts; Mr. Petrie on the Antiquities of the Orkneys; Lord Lovaine on Lacustrian Human Habitations; Professor Beete Jukes on certain Markings on the Horns of Megaceros Hibernicus; Mr. Crawfurd on Sir C. Lyell's Antiquity of Man; Professor Phillips on the Antiquity of Man; Mr. Godwin-Austen on the Alluvial Accumulation in the Valleys of the Somme and Ouse; Mr. Wallace on Man in the Malay Archipelago; Mutu Coomara Swamy on the Ethnology of Ceylon; Mr. Crawfurd on the Origin" of the Gypsies ; Mr. Crawfurd on the Celtic Languages; Mr. Charnock on Celtic Languages; Personal Recriminations in Section $\mathrm{D}$; Concluding Remarks.

Waitz's Introduction to Anthropology. Kingsley's Water Babies.

Lunacy and Phrenology, by C. Carter Blake, Esq., F.G.S., F.A.S.L.

The Rival Races; or, the Sons of Joel.

Ramsay on Geology and Anthropology.

Baruch Spinoza.

Anthropology in the Nursery.

Miscellanea Anthropologica.

JournaI, of THE ANTHROPOIOGICAL SocIETY :

Tylor on Human Remains from MoulinQuignon: Schvarcz on Permanence of Type; Wake on Man and the Lower Animals ; Bollaert on Populations of the New World; Marshall on Microcephaly; Busk on Human Remains from Chatham; Bendyshe on Anglo-Saxon Remains from Barrington; Charnock on Science of Language; W. Reade on Bush Tribes of Equatorial Africa; General Meeting of the Society; Carter Blake on Antiquity of the Human Race. 


\section{ANTHROPOLOGICAL REVIEW.}

\section{CONTENTS OF NO. IV.-FEBRUARY 1864.}

1. On the Human Hair as a Race Character. By Dr. Pruner-Bey.

2. Pott on the Myths of the Origin of Man and Language.

3. Italian Anthropology.

4. On the Scytho-Cimmerian Languages.

5. Notes on Scalping. By Rd. F. Burton.

6. Renan on the Shemitic Nations.

7. Abnormal Distortion of the Wrist. By Charles H. Chambers.

8. Human Remains from Lough Gur, County Limerick.

9. Danish Kitchen-middens. By Charles H. Chambers.

10. Miscellanea Anthropologica.

JoURNal of THE ANTHROPOLOGICAL Society of London:-Carter Blake on the An- thropological Papers read at Newcastle; G. E. Roberts and Professor Busk on the Opening of a Cist of the Stone Age; Captain Eustace W. Jacob on Indian Tribes of Vancouver's Island; Dr. James Hunt on the Negro's Place in Nature; C. R. Markham on Quartz Cutting Instruments from Chanduy, near Guayaquil; $\mathrm{G}$. E. Roberts on Mammalian Bones from Audley End; A. Bryson on Arrow Heads from the Bin of Cullen; Dr. F. R. Fairbank on Flint Arrow Heads from Canada; Count Oscar Reichenbach on the Vitality of the Negro Race; General Meeting of the Society; President's Annual Address; R. Lee on the Extinction of Races.

\section{CONTENTS OF No. V.-MAY 1864.}

An Inquiry into Consanguineous Marriages and Pure Races. By Dr. E. Dally.

Peyrerius, and Theological Criticism. Philalethes.

Miscegenation.

Anthropology inits Connection with Chemistry. Savage Africa.

Ethnology and Phrenology as an $\Lambda$ id to the Biographer. By J. W. Jackson, Esq., F.A.S.L.

Proceedings of the Anthropological Society of Paris.

Correspondence.

Miscellanea Anthropologica.

Journal OF THE ANTHROPOLOgical Society of LONDON :-Lee on the Extinction of Races (continued); T. Bendyshe on the Extinction of Races; Dr. C. G. Carus on the Construction of the Upper jaw of the Skull of a Greenlander; C. Carter Blake's Report on same subject; Jas. Reddie on Anthropological Desiderata; Rev. J. M. Joass on some Pre-historic Dwellings in Ross-shire; with an Introduction by George E. Roberts; C. Carter Blake on the Alleged Peculiar Characters, and assumed Antiquity of the Human Cranium from the Neanderthal; Alfred R. Wallace on the Origin of Human Races, etc.

\section{CONTENTS OF NO. VI.-AUGUST 1864.}

On the Distinction between Man and Animals. By Philalethes.

On the Phenomena of Hybridity.

Thoughts and Facts contributing to the History of Man.

On the Importance of Methodical Classification in American Researches. By A. De Bellecombe. Translated by W. H. Garrett, Esq., F.A.S.L.

Anthropotomy.

Doyle's Chronicle of England.

Anthropological Documents of the State of New York. By Geo. E. Roberts, Esq., F.G.S., Hon. Sec. A.S.L.

Doherty's Organic Philosophy.

Proceedings of the Anthropological Society of Paris.

The Fossil Man of Abbeville again.

Miscellanea Anthropologica.

Journal of THE ANTHRopological Society of LoNDON :-Wallace on the Origin of Human Races (continued discussion);
Schlagintweit on some Ethnographical Casts, etc.; Dr. Shortt on the Domber ; Pike on the Place of the Science of Mind and Language in the Science of Man; Guppy on the Capabilities of the Negro for Civilisation; Farrar on the Universality of Belief in God, and in a Future State; Farnar on Hybridity; Burton and Carter Blake on Skulls from Annabom in the West African Seas; Thurnam on the Two Principal forms of Crania in the Early Britons; Bollaert on the Palæography of the New World; Bendyshe on the Precautions which oughi to have been taken to ensure the health of British Troops had any been sent to Copenhagen ; Roberts and Bolton on the Kirkhead Cave, near Ulverstone; Blake and Roberts on Human Remains from Peterborough; Bollaert on the Alleged Introduction of Syphilis from the New World, etc. 
$e / i$

$$
\frac{y, i}{1}
$$


$\sqrt{x}$ 


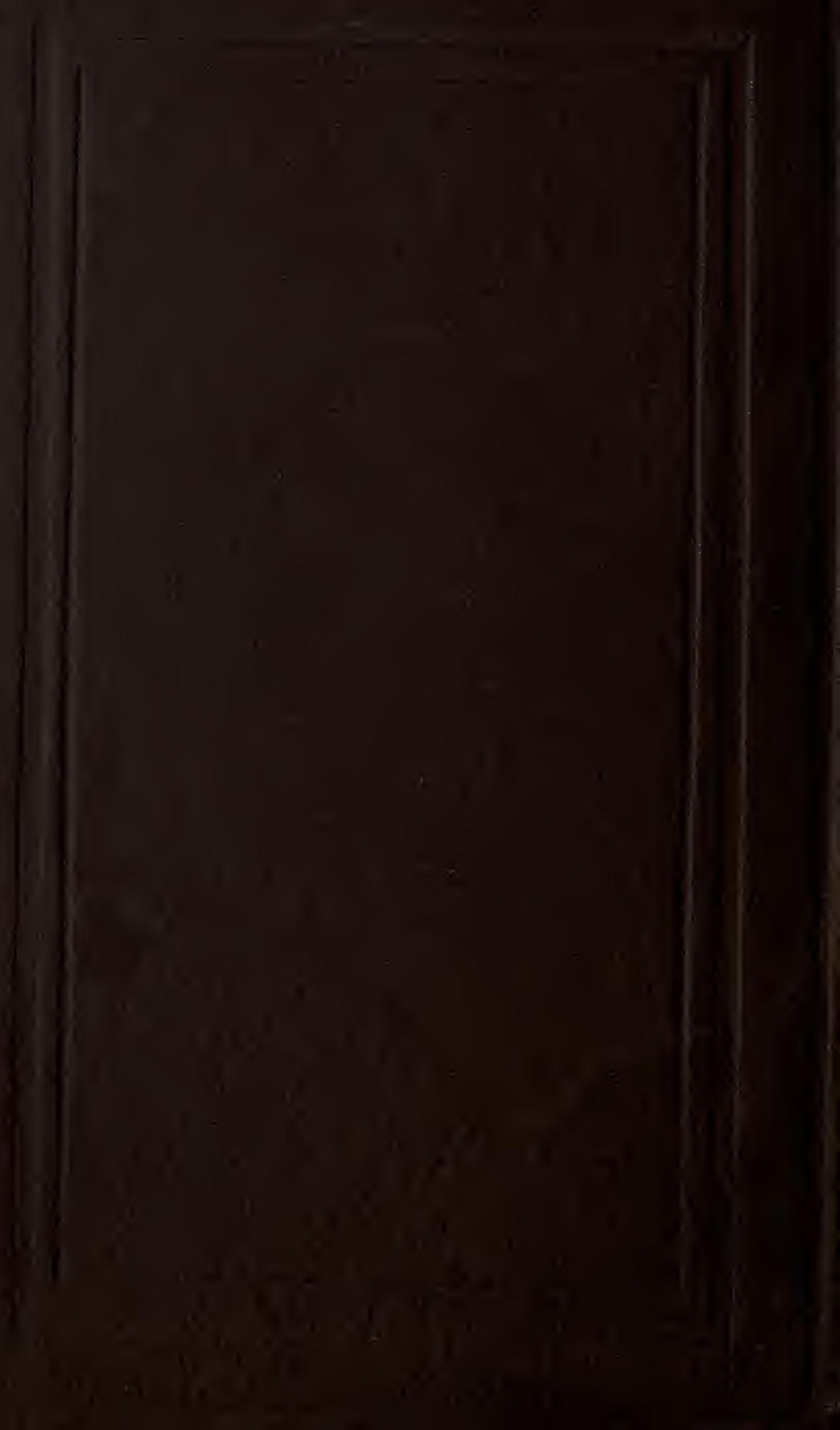

